\title{
CONSTRUCCIÓN TEXTUAL EN LOS SONETOS DE LOPE DE VEGA: TIPOLOGÍA DEL MACROCOMPONENTE SINTÁCTICO
}

A don José Manuel Blecua, sin cuyas ediciones trabajos como éste no serian posibles.

\section{Necesidad de una tipologia del macrocomponente de construcción textual}

0.1. Este artículo se incluye en el conjunto de nuestras investigaciones tipológico-textuales sobre la lírica del Siglo de Oro. En nuestra primera aportación Lingüística del texto y texto lírico ' ${ }^{\prime}$ en lo sucesivo citaremos este trabajo por la abreviación L. T. T. L. - abordamos el problema de la tipología temática del soneto amoroso clásico sobre una muestra de quinientos textos de cuatro poetas españoles: Garcilaso, Herrera, Quevedo y Góngora. El segundo trabajo de esta serie, Tipología textual y análisis del microcomponente (sonetos españoles de "Carpe diem.) 2, supuso el

' Dicho trabajo constituyó nuestra ponencia en el I Simposio sobre investigación lingüistica de la Literatura, celebrado en la Universidad de Rio Piedras (Puerto Rico) en 1977, las actas aún no se han publicado; una segunda exposición, corregida, la realizamos en la Ĺniversidad de Montpellier, en el semo de uno de los coloyuios del C. R. S., y se publicó en la revista «Imprévu*, 1978 (1-2), pp. 18Г-233. La versión española fúe publicada en la «Revista de la Sociedad Española de Lingüística», 8, 1, 1978, pp. 19-75, si bien con numerosas erratas, ajenas a la responsabilidad del autor. La consulta más recomendable es su publicación en el capítulo 9 del libro de J. S. Petöfi/A. García Berrio, Lingüistica del texto y crítica literaria, Madrid, Comunicación, 1979, pp. 311-366.

2 Inicialmente fue la contribución a un Simposio en la Universidad de Toulouse, en 1978, publicada en las actas de dicha reunión. L'ideologique dans le Texte. Versión modificada es la publicada en Estados Unidos en "Disposition, III, 9, 1978, pp. 243-293. Este trabajo ha sido incorporado, con retoques, al libro Lingüistica del texto y crítica literaria, cit., pp. 369-430. Del estado más avanzado de la teoría daba cuenta, a finales de 1979, nuestro articulo, A Text-typology of the Classical Somnis, en «Poeticsw, 8, 1979, pp. 435-458. 
desarrollo en detalle de uno de los ochenta tópicos, terminales temáticos, sistematizados en L. T. T. L., el correspondiente al «carpe diem»; planteándose ya en concreto, entre otros de menos relieve, los problemas siguientes: a) inordinación de la fórmula temática inicial del soneto amoroso a otras fórmulas temáticas y a fórmulas de conjuntos más generalizados: soneto, género de la lírica, etc.; b) transformaciones textuales del soneto en estructuras más extensas y más breves con el mismo tema; c) relación entre el macrocomponente y el microcomponente textual, en el plano temático y en el plano macrosintáctico.

Como puede verse, en el articulo anterior quedaba ya planteada la cuestión de la sintaxis textual, de la organización del tema, a través de una argumentación precisa, en un texto construido con un orden y una estructura expositiva concretos, que es, precisamente, lo que queremos aportar en nuestro trabajo actual. Esto en el plano teórico-lingüístico; en la vertiente histórico-literaria que pretende servir esta teoría, hemos cubierto un vacio importante de L. T. T. L., el que creaba la ausencia de Lope de Vega. De la muestra acogida en nuestra exposición inicial temática lo excluiamos por razones de economía de tiempo; el «corpus» tipologizado era va suficientemente representativo, quinientos textos. Sin embargo, nunca hemos dudado de la imprescindible exigencia de incluir a Lope en cualquier consideración sobre la poesía lírica del Siglo de Oro. Como demostraremos a lo largo de este trabajo, la genialidad innovadora de Lope de Vega se evidencia bajo cualquier faceta de su producción artística. No sólo en su dramaturgia, sino en el conjunto total de su obra, y por consiguiente en su poesía lírica. Para una aportación inmediata de nuestra serie de trabajos tipológicos, queda la explícita incorporación de los sonetos amorosos de Lope, entre otros escritores, a los textos de nuestra tipología temática; donde se pondrá de manifiesto la singularidad radicalmente antitópica de su carácter. Por ahora, la necesidad de considerar a Lope de Vega - y aun de manera central- queda resuelta en el ámbito de la tipología sintáctica.

0.1.1. El "corpus" de textos vinculados a esta nueva tipología sintáctico-textual lo constituyen quinientos sonetos de Lope, de tema variado: amorosos, religiosos, morales, conmemorativos y burlescos. Si a éstos se añade la consideración de los otros quinientos textos amorosos, ya analizados bajo la perspectiva semántico-temática en L. T. T. L. y ahora también incorporados a nuestra analítica sintáctica, $x^{\circ}$ comprenderán las dificultades de nuestro trabajo. Que sepamos, no son tantos los estudios existentes que tomen en consideración, con ninguna finalidad orgánica y sistemática, un conjunto de mil textos literarios. Sin embargo, entiéndase que no decimos lo anterior para imponer a nadie nuestro esfuerzo, que 
en (ualquier (aso es un trabajo muy gratificador. Si lo ponderamos es para justificar precisamente sus limitaciones, y más que nada su provisionalidad en muchos aspectos. Dectarar la provisionalidad de un trabajo es un presupuesto a nuestro juicio casi obligatorio en un entendimiento moderno y consciente de la ciencia. Que en la filología española no suela ser frecuente, es algo que, sencillamente, no nos impresiona. Mídase el esfuerzo y las aportaciones de quienes hoy en todo el mundo trabajan bajo unos y otros presupuestos, y saque cada cual sus consecuencias.

Como en L. T. T. L., nos apresuramos a confesar la provisionalidad de nuestro análisis en detalles concretos. Todo trabajo tipológico sobre una muestra significativa y realista - lo otro es una pura ficción- se asienta siempre sobre una base inevitablemente inestable: la rapidez y la indescontable exigencia de soluciones unívocas en su análisis de base de los textos concretos. Por varias razones nuestras decisiones analíticas sobre cada soneto pueden quizá ser inexactas en algunos casos. Lo sabemos y no nos importa demasiado. Si el lector de buena fe descubre algunos textos en los que discrepe de nuestra propia decisión, y si ésta fuera incuestionablemente errónea, corrija simplemente por su cuenta. No obstante, creemos honradamente que tales casos, que precisarian nuevos recorridos del «corpus» - nuestros y quizás mejor de todo un equipo de encuesta-, no son tantos como para invalidar, ni mucho menos, las líneas generales de la tipología.

Obviamente nos proponemos en el futuro ir corrigiendo la teoría general subyacente a nuestros estudios tipológicos y también, claro está, todos los errores de detalle que descubramos, o que otros, alumnos o lectores, nos hagan descubrir. Sin embargo, insistimos en ello, el escrúpulo de provisionalidad en este sentido, que creemos que razonablemente nadie podría descartar en trabajos de esta indole, no debe impedir la elaboración y difusión de estos estudios tipológicos, una vez que se ha alcanzado una razonable y honrada madurez. Lo requiere, a nuestro juicio, la situación actual de las disciplinas lingüísticas que se interesan en el texto como objeto de estudio y unidad del más alto y complejo nivel lingüístico. Y lo exige también, perentoriamente, la situación de las metodologías crítico-literarias de encuesta textual y : nivel de conocimiento que establecen los presupuestos de la historia literaria. No juzgamos que sea éste el momento de abordar explícitamente las aportaciones que la consideración tipología puede brindar al enriquecimiento de la concepción del texto, que tratan de alcanzar en nuestros días las gramáticas textuales. Tal consideración, que constituiría un trabajo sin 
duda extenso y autónomo, la diferimos para un próximo avance de nuestro desarrollo de la teoría tipológico-textual ${ }^{3}$.

0.1.2. Análogas razones de limitación y provisionalidad de este tipo de trabajos -quizá en este caso menos perceptibles al lector español, pero, sin duda, más importantes en conjunto que las anteriores - son las derivadas del modo en que frecuentemente nos vemos obligados a asumir y resolver en el trabajo tipológico-textual problemas en la práctica analítica previa y en la propia sistemática tipológica, que distan mucho de ser cuestiones definitivamente estabilizadas en lingüística. Si en el dominio de L. T. T. L. los problemas teóricos asumidos básicamente se referian a la determinación y la jerarquización temática, así como a la eterna cuestión de límites entre sintaxis y semántica para el establecimiento tipológico de tópicos como el galanteo, el símil, o algunas modalidades del confidente; en el caso de la tipología actual sintáctica los problemas básicos sin duda son el de la aún imprecisa definición de la macroestructura textual y sus reglas transformativas y constitutivas, y muy directamente conectada con él, la cuestión de los límites entre macro y micro-componente textuales. Ya que, digámoslo desde ahora mismo, nuestro propósito y entendimiento actuales de lo que de tipologizable hay en el texto de los sonetos literarios clásicos, no rebasa los límites de la macroestructura. Pero antes de extendernos, aunque sea brevemente, en la exposición de los problemas teórico-lingüísticos que subyacen a nuestro trabajo, parece conveniente aquí señalar también las razones de necesidad y urgencia que justifican, y a nuestro modo de ver exigen por estrictas razones científicas, aligerar los razonables escrúpulos de provisionalidad.

Pero es que creemos que, además, existe otra posible razón de fuerza mayor para obviar tales escrúpulos en el caso de nuestras propuestas actuales. Al estudio tipológico macroestructural de la lírica de Lope de Vega, y en general del conjunto de la lírica clásica, nos han compelido perentorias razones de urgencia científica. La historia de la poesía lírica española en el Siglo de Oro -y casi me atrevería a geneneralizar en universal a la historia de la lírica clásica en todas las literaturas- está absolutamente desiasistida de las adecuadas categorías de enjuiciamiento

\footnotetext{
${ }^{3}$ Acabado este articulo en el verano de 1979, con posterioridad hemos ido estableciendo los jalones teórico-lingüisticos que prometiamos en el texto. De próxima aparición en español son los trabajos sobre determinación/jerarquización del tema en el texto, así como el correspondiente a la problemática lingüistica creada por la focalización temática del texto en un elemento axial de la estructura predicactancial básica, confidente o circunstante. Una síntesis en inglés de estos problemas lingürsticos aparecerá en 1981 en la revista «Text".
} 
tipológico. Una tradición científica y crítica que sin ningún desdén podemos calificar de brillantísima, ha seguido los pasos de cada estilema concreto en el dominio de la estilística sintagmática, ha analizado cientos, millares de poemas como productos únicos, hechos artísticos singulares, que lo son a no dudarlo en especial en el caso de las grandes creaciones; cuando más, se ha planteado el itinerario de fortuna de un tema a través de un conjunto de textos más o menos inmediatos, y más raramente ha hecho lo mismo con un recurso formal.

Pero me parece que queda claro que, al menos para el tipo de determinaciones que interesan a la historia literaria, tan importante, al menos, como el análisis de lo que un texto lírico, un poema, un soneto tenga de singular, de único, es el conocimiento de lo que tiene de general, de componente tópico; es decir, la determinación del límite generalizado cultural desde el cual parte el poeta - singularmente en la consideración clásica de un arte de "retractatio», cuyas últimas consecuencias alcanzan sin duda la lírica romance de los siglos XVI y XVII- a la hora de crear un nuevo texto. En otros términos, mientras la analítica poemática individual, practicada como hermenéutica de las bellezas por la estilística tradicional y la lectura de textos, ha tendido de modo básico a la determinación explícita de los mecanismos artísticos de la poeticidad como valor, la tipologización macroestructural, tal como la que nosotros venimos practicando para el caso de la lírica clásica y que hoy nos proponemos desarrollar en el de Lope de Vega, se plantea el camino inverso y complementario; es decir, a través del establecimiento de los tipos generales tradicionales -en inventarios limitados descritos rigurosamente y formalizados de modo orgánico-, establecer el ámbito inicial tópico sintáctico-semántico que pertenece aún al dominio de las decisiones pragmáticas consensuadas socialmente como literariedad.

Si desde Ta consideración teórica de un solo poema evocamos el vacío existente en la historia literaria tradicional en el ámbito del establecimiento estricto, no intuitivo y aproximado, de tales marcas descriptivas, semejantes a las que pretenden ofrecer consideraciones tipológicas como las nuestras, creo que se hacen incuestionables - al menos así se nos han hecho a nosotros- las razones de urgencia. Ni la historia literaria tradicional para el dominio de los sectores por definición tópicos de la literatura clásica, ni la analítica concreta de un autor o de un poema deben seguir siendo ejercidas, a nuestro juicio, sin el auxilio, previo si se quiere pero imprescindible, de las tipologías.

El tipo de servicios que a la interpretación última de un poema como obra de arte pueden ofrecer, es quizás, como hemos dicho, menor o simplemente previo; pero la índole de esos mismos. servicios multipli- 
cada por el conjunto total de los textos individuales bajo posible análisis crece enormemente; y con ello el valor ilustrativo y explicativo de las grandes corrientes de literariedad en la historia literaria se nos antoja absolutamente imprescindible. Su urgencia e importancia, como única vía de reconocimiento de la tradición literaria, creo que pueden acallar para nosotros, como críticos e historiadores de la literatura, todos los escrúpulos de provisionalidad e incompletez categorial que nos podamos ir planteando como lingüistas; con el mejor deseo - claro está- de ir incorporando cuidadosamente toda novedad producida por la lingüística en el pulido especulativo al cuadro teórico de nuestro entendimiento de ese objeto lingüístico complejísimo que llamamos texto, y que constituye la unidad básica de cualquier construcción tipológica.

0.1.3. Todo lo precedente nos lleva ahora a extendernos a un tercer ámbito de provisionalidades que, voluntariamente, hemos asumido. En este caso, quizá, la explicación sea más pertinente para los hispanistas o para los lectores españoles de este trabajo. Obviamente, hoy, el plantearse cualquier aspecto, incluso hasta los más pequeños o desdeñables, de cualquier problema científico de entidad, o, en el caso de los estudios literarios, de cualquier autor importante, impone el repaso y mención de una cantidad ingente de estudios anteriores. Como se verá, en este artículo nosotros hemos prescindido casi totalmente de toda mención bibliográfica; pese a que el problema que afrontamos no es, ni muchos menos, de índole menor, y los cinco poetas que involucra nuestro análisis forman sin duda en la decena de los más importantes escritores de nuestro país, sobre los que existe, naturalmente, una rica tradición bibliográfica, que sería en todo caso colateral a nuestro objeto.

Pero en la elaboración de todos nuestros trabajos en este campo hemos partido de la base, creemos que razonablemente constatada, de la inexistencia de antecedentes rigurosos y exhaustivos de tipologización textual para nuestra lírica clásica. Tampoco aquí pretendemos cargar a nadie de culpas, ni a nosotros de méritos: simplemente nosotros mismos. aun sólo diez años antes, tampoco hubiéramos podido abordar seguramente un trabajo de tipologización macrotextual, porque faltaban las condiciones científicas para ello, como lo puede atestiguar una tesis bien construida y rigurosa, pero carente de toda reflexión textual. cual es la monografía tradicional de Otto Jörder. Faltaba sobre todo la propia imagen de la entidad lingüistica texto, que se nos ha brindado en numerosísimos trabajos recientes de varias escuelas; singularmente para nosotros desde la lingüística alemana. Contanto con tal ausencia general. y con las razones de urgencia y necesidad del trabajo antes expuestas. de que partimos, hemos desatendido hasta ahora la exhaustiva búsqueda de 
aportaciones o detalles, más o menos próximos a los nuestros, en la abundante bibliografia de los autores concretos. Razones prácticas muchas veces de nuestra dificil actividad habitual en centros universitarios españoles mal dotados de buenas $\longrightarrow$ aun de malas- bibliotecas, así como nuestra decisión de abordar con urgencia los problemas y las necesidades mayores, nos han apartado hasta el presente de tal tipo de consultas. Quede por ahora reconocida nuestra deuda con los posibles autores no citados que, a la hora de dar por definitiva esta teoría, trataremos de resolver con toda largueza ${ }^{4}$.

0.2. Como decíamos antes (0.1.2), el problema teórico básico que subyace a este artículo es el cuadro aún no definitivamente establecido de la macroestructura, especialmente en lo que se refiere a la imprecisa delimitación entre macrocomponente y microcomponente textual. La nuestra, como también se ha dicho ya, es una tipología del macrocomponente sintáctico del texto-soneto. Por tanto, en nuestro análisis quizás hayamos arrastrado, con frecuencia, problemas derivados de tal indeterminación. Sin embargo, creo que lo que puede estorbar son los

\footnotetext{
4 En otro nivel se nos habrá de disculpar no marcar con suficiente explicitud en este trabajo la nómina de deudas a las fuentes de nuestra propia formación en la analítia poemática de estos autores, asi como de nuestra orientación en la situaxión históricoliteraria y cultural. Pero en un artículo de la extensión y las peculiaridades metoxdológixas de éste. tal tipo de explicitaciones lo habrian hecho definitivamente impracticable, no añadiendo a los lectores, por bo demás, nada que juaguemos imprescindible. Pero (onmo consideramos el nuestro un trabajo únicamente explicable desde una tradición científica que pretendemos humildemente continuar, a través de la imprescindible revitalización que supone obligatoriamente en ciencia la búsqueda de nuevos métodos y puntos de vista, nos parece aquí obligada la mención de nuestras deudas muy concretas, para este campx), con don Marcelino Menéndez. Pelayo, y nuestro inolvidable maestro don Angel V'albuena Prat. En el caso de nuestro autor concreto, en su aspecto biográfico, hemos tenido en cuenta sobre todo la obra tradicional Vida de Lope de Vega, de Hugo A. Rennert y Américo Castro, Salamanca, Anaya, 1969. Entre las no abundantes monografías sobre la lírica de Lope, aun con intereses muy distintos a los que nos ocupan aquí, recordariamos los trabajos incluidos en J. F. Montesinos, Estudios sobre Lope de Vega, Salamanca, Anaya, 1969. En cuanto a la edición de Lope elegida, ha sido la de J. M. Blecua, Obras poéticas, Barcelona, Planeta, 1969, de cuyas útiles sinopsis introductivas nos hemos servido con frecuencia para muchas corroboraciones. $Y$, dentro de sus peculiaridades doctrinales, hemos tenido en cuenta la monografía más centrada en nuestro tema de que tenemos noticia. Se trata de del libro de Otto Jörder, Die Formen des Sonetts bei Lope de Vega, Halle, Max Niemeyer, 1936 (Anejo LXXXVI de "Zeitschrift für romanische Philologie*. Por último, no creo que pueda decirse que ningún filólogo español se haya sustraído al magisterio, directa o indirectamente gustado, de la analítica estilística de Dámaso Alonso, Poesia española (Madrid, 1971, reimp.) es un libro que, de uno u otro modo, ha estado presente en un largo periodo de mi formación, en torno a la lírica del Siglo de Oro, que aboca ahora en estos trabajos.
} 
nuevos términos. Tratemos, por tanto, de explicar aquí de otro modo el límite textual macro-microestructural que nos hemos fyjado.

Quizá la fórmula común - seguramente por pura casualidad inconsciente- más prestigiosa, pertinente al repertorio de tecnicismos lingüisticos-textuales y al tradicional, sea la de construcción. Aunque el concepto de construcción puede afectar, en buena logíca, al conjunto de operaciones lingüisticas y marcas operacionales de la elaboración de un' texto, desde la fijación inicial del tópico del discurso hasta su manifestación lineal terminal como texto plasmado; sin embargo, el término aparece regularmente restringido al uso macrosintáctico textual. Supongamos, por ejemplo, el caso de un soneto de carpe diem. Aquí es claro que por construcción de este texto pensamos: a) en los conjuntos-unidades básicos que, sucesivamente soldados, constituyen la exposición del tema, y b) en los conectores implicitos y explicitos que establecen la solidaridad de los conjuntos-unidades en el conjunto textual. Tradicionalmente quizá se hablaba de clóusulas, en terminos aproximadamente análogos a los que nosotros hemos denominado aquí conjunto-unidad textual; sin embargo, el concepto de cláusula, no desdeñable en sí mismo, aparece bastante desdibujado por una hoy ya innegable dosis de ambigüedad e indeterminación.

Vinculada a la tradición de la concepción sentencial del discurso, que establecía la imagen del texto como agregado sucesivo de sentencias s, la cláusula se ha concebido, por tanto, como un limite de progresión de la sentencia. Pero al descuidarse tradicionalmente la idea del término final de la progresión, el texto, la cláusula ha quedado inocultablemente indeterminada. Si se contempla la cláusula, por el contrario, desde la perspectiva de la sintesis textual, sus límites quedan mucho mejor establecidos 6; en la medida en que, en el aspecto sintáctico, los conectores interclausulares establecen unos jalones explícitos de tales delimitaciones, y sobre todo

\footnotetext{
' Una sinopis pre-textual de nuestro propio análisis de la tradición de la sintaxis frástica en el dominio de la integración de frases en el dixcurso, que constituye el sustento de estas ideas -enriquecido en las fuentes de Tesnière, Bröndal, Bally, etc...-, la ofrecimos hace años en nuestro estudio Bosqugio para una teoria de la frase compruesta en espanid, Murcia, Universidad, 1970. Recientemente $s e$ ha hecho eco de nuestras propueatas. G. Rojo, en su interesante obra Clóusulas y oraciones, Santiago de Compostela, Universidad, 1978.

- Sobre la situación actual de los problemas de límites entre concepción sentencial y textual del discurso, la más reciente y completa aportación existente son los dos volúmenes de J. S. Petöfi (ed.). Text us. sentence, Hamburg, Buske, 1979 (Papiere zur Textlinguistik, 20). Entre las numerosas aportaciones sobre el tema incorporadas, figura una nuestra donde nos planteamos distintas cuestiones teóricas a este problema, en Vol. I.
} 
en el ámbito semántico-temático cada una de las cláusulas viene definida, no en torno al ambiguo concepto tradicional de unidad de sentido corriente en la sintaxis sentencial, sino al más concretable de parteparticipante del sentido global del texto. Con lo cual, la identidad concreta de la parte resulta fácilmente establecible en la relación parte-todo. Para desambiguar, por tanto, el concepto de cláusula - frecuentemente manejado, por otra parte, en este estudio- es por lo que hemos propuesto antes su sinónimo explicativo de conjunto-unidad del texto.

0.2.1. Obviamente, el soneto constituye un tipo de texto muy especial, en el que los problemas de establecimiento de las unidades de construcción se ven enormemente simplificados por el relieve inequívoco de su estructura métrica explícita. En principio, la atención del análisis de la construcción se centra básicamente en el funcionamiento de las marcas conectivas ${ }^{7}$, las delimitativas, y los hechos de relevancia y solidaridad semántica recíproca entre las cuatro estrofas, dos cuartetos y dos tercetos, que lo componen. Generalmente dichas cláusulas métricas coinciden con las sintáctico-semánticas textuales, bien sea agrupadas en dos cláusulas-unidades cuartetos/tercetos, bien cada una de las cuatro autónomamente.

Por consiguiente, podemos determinar ya aquí un límite práctico a la macroestructura del soneto, en la dimensión de su construcción sintáctico-constructiva, en torno a: a) la determinación de la correspondencialno correspondencia de estrofas-cláusulas métricas y conjuntosunidades de construcción, y b) especificación de marcas interclausulares explícitas e implícitas en un triple orden: delimitativas, conectivas y de relevancia $^{8}$. Del examen de las referidas marcas constituyentes resulta evidenciada la estructura básica de la construcción textual, que podemos considerar asimismo el organismo sintáctico de base de la macroestructura ${ }^{9}$. Entendién-

\footnotetext{
' Para una visión actual introductiva a la compleja cuestión de los conectores, vista desde el ángulo muy relevante de la teoría del texto, consúltese C. Biasci, Konnektive als Grundelemente der Texte, en C. Biasci/J. Fritsche (eds.), Texttheorie-Textrepräsentation, Hamburg, Buske, 1978 (Papiere zur Textlingüistik), pp. 117-191.

- Para una aclaración del concepto de relevancia como correlación recíproca sintácticosemántica entre las distintas piezas textuales, cfr. Teun A. Van Dijk, Relevance in Grammar and Logic, Contribución al I Congreso de Lógica de la relevancia, San Luis, 1974, mecanografiado. El concepto ha sido aclarado en J. S. Petöfi/A. García Berrio, Lingüustica del lexto y crítica literaria, cit., pp. 56-77.

- Decisiva aportación a la definición de la macroestructura textual, como complejo de unidades relacionadas a través de dos sistemas de mecanismos correlatores, de coherencia y de conexividad, que operan de modo distinto a diferentes niveles de consideración de la macroestructura textual, es el estudio de J. S. Petöfi, Connexity, Coherence, Theory of Text, en F. Neubauer (ed.), Coherence in natural languages, Hamburg, Buske, 1981 (en prensa).
} 
dose, por consiguiente, que la especificación de otras marcas conectivas, delimitativas y de relevancia que establezcan subagrupaciones en el seno de las cláusulas-unidades textuales sintáctico-semántico-métricas, correspondería ya a procesos relativos al microcomponente textual, que desde nuestro actual punto de vista son irrelevantes para una tipología de la indole de la que aquí abordamos.

El límite anteriormente aludido quedará de manifiesto con un ejemplo. Pongamos el de una estructura muy bien delimitada sintácticosemánticamente, el tópico del carpe diem en el soneto de Garcilaso: «En tanto que de rosa y d'azucena». El límite macro-microtextual quedará definido tras la delimitación de las siguientes series:

Semántica

Sintáctica

Métrica

a)

\begin{tabular}{|c|c|c|}
\hline $\begin{array}{l}\text { Serie de ponderación } \\
\text { de la hermosura. }\end{array}$ & $\begin{array}{l}\text { a) Conectores-delimitadores En tanto... y } \\
\text { en tanto. } \\
\text { b) Marcas de relevancia: adjetivación positiva } \\
\text { de los componentes de la descripción «re- } \\
\text { trato", etc., y lexemas de ponderación. }\end{array}$ & Cuartetos \\
\hline Exaltación epicúrea. & $\begin{array}{l}\text { a) Conexión interclausular circunstancia- } \\
\text { mandato. } \\
\text { b) Marca de relevancia: imperativo coged y sus } \\
\text { términos. }\end{array}$ & Terceto 1 \\
\hline $\begin{array}{l}\text { Proceso de degradación } \\
\text { de la hermosura }\end{array}$ & $\begin{array}{l}\text { a) Delimitadores: cambios de perspectiva } \\
\text { temporal-verbal. Tiempos en futuro: mar- } \\
\text { chitará, mudará. } \\
\text { b) Marcas de relevancia: adjetivación negativa } \\
\text { y lexemas de degradación. }\end{array}$ & Tercero 2 \\
\hline
\end{tabular}

0.2.2. Definido explícitamente, como acabamos de hacer, el límite conceptual sintáctico-semántico de la macroestructura textual, al menos para el caso del texto-soneto, conviene quizá delimitar terminológicamente los ámbitos y operaciones de la macro- y la micro-estructura. Por tratarse el soneto de un tipo de discurso esencialmente expositivo/no narrativo, en el que el emisor vincula la expresión a su propia experiencia, y cuenta, explícita o implícitamente, con el lector como destinatario indirecto o destinatario del enunciado y con frecuencia con el término de la apelación - la dama, el amor, el confidente, etc. - como destinatario directo, destinatario de la enunciación, podemos considerar el tipo expresivo más habi- 
tual de los sonetos líricos clásicos absolutamente semejante a la modalidad argumentativa de discurso.

Tecnicismo corrientemente acuñado ya en la teoría del discurso ${ }^{10}$, el término de argumentación $\longrightarrow$ alguno más genérico y tradicional como el de construcción - sustituyen, a nuestro juicio beneficiosamente, al de macroestructura sintáctica como objeto y límite de una tipología textual como la nuestra; porque, siendo absolutamente apropiado el género de estructura constructiva del macrocomponente que incorporan los sonetos, tiene la ventaja suplementaria de no precisar ninguna especificación conceptual para contraponer el tipo de marcas, unidades y operaciones microtextuales, habitualmente designadas ya como sintácticas, tanto en el entendimiento tradicional de la sintaxis sentencial, como en el de los primeros pasos y escalones inferiores microcomponenciales de la teoría del texto.

El paso equivalente en el dominio semántico sería quizá la análoga distinción entre microestructura semántica y macroestructura temática ", para aplicar el resultado a los dos niveles textuales correspondientes. Sin embargo, la noción de tema no aparece en principio tan absolutamente perfilada y relativamente inédita como la de argumentación. En la crítica literaria tradicional el tema no tiene siempre necesariamente, aunque sí desde luego de modo mayoritario, alcance macrotextual. Por otra parte, y éste es el principal problema que vemos a su adopción universal, la noción tradicional de tema desborda con mucha frecuencia los límites de lo estríctamente semántico. Así, en el tema del carpe diem,

\footnotetext{
${ }^{10}$ No obstante, el concepto de argumentación exige todavía numerosas pruebas y verificaciones antes de su posible aplicación a diferentes tipos textuales. En nuestro caso se trata de una propuesta generalizable a la mayoría de los sonetos. Sin embargo, no cabe duda que su más inmediata e incuestionable validez se ofrece en el dominio de las construcciones textuales lógico-discursivas, con un proceso de convicción o demostración explícitamente subrayado en el texto. De este modo los sonetos de construcción narrativa no deben ser considerados estrictamente dentro de la construcción argumentativa. El desarrollo de la noción de estructura argumentativa procede hasta el presente de la teoría lógica, y entre sus aplicaciones más recientes a los procesos macrosintácticos de la metalengua científica, véase: Arne Naess, Kommunikation und Argumentation, Kronberg. Ts., Scriptor, 1975. No obstante, recuérdese que el soneto fue, históricamente, un texto discursivo por definición -no narrativo-, que incorporaba el desarrollo lógico de un argumento concreto. Desde Dante las discusiones sobre el soneto y, en general, sobre la licitud como género literario de la poesía lírica, a la que se acusaba de su carencia de fábula o imitación de acciones, quedó zanjada precisamente mediante la acertadísima solución de proponer el tema argumentado, concetto, como fábula de la composición.

"El más reciente y complejo planteamiento de los conceptos de tema y determinación temática es el libro de Linda Kay Jones, Theme in English Expasitory Discourse, Lake Bluff (Illinois), Jupiter Press, 1977.
} 
antes propuesto como ejemplo, resulta evidente la indisoluble vinculación de las estructuras semánticas con las propiamente sintácticas. Por lo demás, la naturaleza no específicamente semántica de la tipología abordada en este artículo no nos fuerza a una resolución tan urgente para la pareja tema/microcomponente semántico del texto, como lo es sin duda para la dualidad argumentación/microcomponente sintáctico del texto.

En este trabajo alternarán las denominaciones de construcción narrativa, y sobre todo de argumentación $\longrightarrow$ construcción argumentativa - y macrocomponente sintáctico, siempre que la responsabilidad del contexto no nos obligue a precisiones más estrictas, en las que comparecerán comúnmente construcción o argumentación, según el valor que corresponda. Nuestra utilización de la dualidad temático-semántica es aún más libre. Por lo regular, las ocasiones en las que se utiliza la denominación tema, son aquellas en que su uso en términos explícitos de macrocomponente semántico no entra en conflicto con el entendimiento tradicional del tema 10 bis.

0.3. El orden de nuestro método al presentar la estructura tipológico-argumentativa ha sido el siguiente:

0.3.1. En primer lugar hemos elaborado un esquemá tipológico de partida sobre unos ciento cincuenta sonetos amorosos de las Rimas de Lope (1609), según el criterio básico de distribución de cláusulas argumentativo-métricas y modalidades de expresión. Aquí sintetizamos el contenido del mismo según el diagrama arbóreo de la figura 1, que corresponde con los cuadros gráficos incluidos en el apéndice.

Fig. 1.

CONSTRUCCION

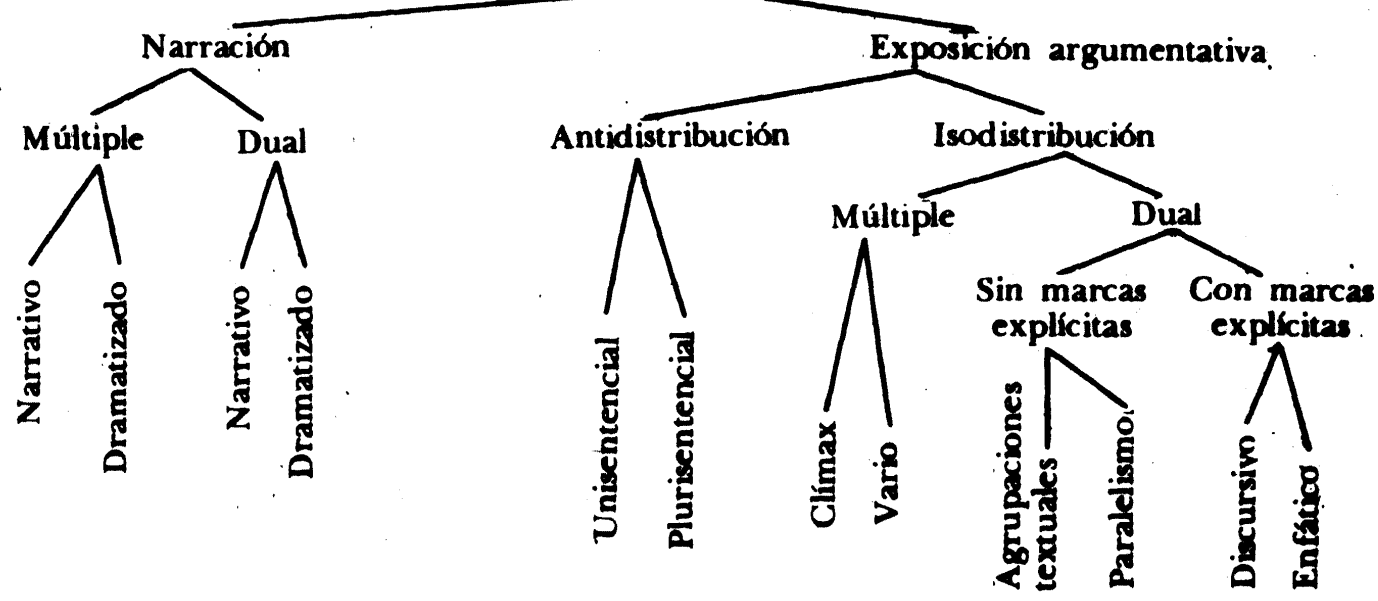

10 bis En la actualidad consideramos la noción global tradicional de «tema» imprescindiblemente deslindada dentro del desarrollo del esquema básico predicactancial del texto, en sus componentes: a) génere temático, basado en presuposiciones macrotextuales; b).claw temática, de naturaleza sintáctico-semántica, y c) agregación somántica terminal. 
Las posibles dudas sobre términos del gráfico anterior aún no explicados, quedarán solventadas en los capítulos sucesivos (l y 2) de este trabajo.

0.3.2. Realizado el esquema tipológico inicial sobre la muestra amorosa (cuadro 1 del apéndice), el paso siguiente ha sido verificar si dicho esquema es o no aplicable a textos de contenido temático distinto, con el resultado positivo que evidencia el apartado correspondiente 3 y los gráficos del apéndice (especialmente cuadro 2). Habiendo sido realizado básicamente el esquema inicial tipológico sobre textos correspondientes al Lope más juvenil, publicados entre 1602-1609, procedía contrastarlo con las colecciones líricas más tardías de Lope, publicadas en el período 1624-1634, para estudiar la posible evolución personal de Lope en su práctica de producción de textos líricos; habiéndose confirmado, en efecto, una línea de progresivo abandono de tipos argumentativos inicialmente muy reiterados, e inversamente; cumpliéndose así el mismo proceso antitópico que evidencia la evolución temática de Lope (gráficos 3 y 4 del apéndice).

Por último - apartado 5- procedía examinar el esquema tipológico argumentativo establecido para Lope de un modo generalmente aceptable, aun con sus variables de evolución cronológica, en relación con la producción lírica de otros autores clásicos. El interés de la investigación en este punto, como fácilmente se podrá suponer, era determinar si dicho esquema tipológico, elaborado "ad hoc» para Lope como consecuencia del análisis de sus sonetos, era o no generalizable como tipología constructiva general de los sonetos en la lírica clásica. El conjunto de textos convocado a contraste con los quinientos sonetos de Lope han sido los también quinientos sonetos amorosos temáticamente examinados en L. T. T. L. El resultado ha sido igualmente afirmativo, dentro del grado de generalidad máxima que fuerza, a cualquier tipo de conclusiones, la esquematización tipológica de una muestra verdaderamente representativa de textos artísticos, reales, históricos (gráficos 5-8 del apéndice).

\section{Macroestructura de la construcción. Actantes y modalidades expresivas}

\subsection{Clases generales}

En la conciencia íntima del creador lírico era sin duda determinante la tradición preceptiva centrada en los actores del episodio lírico amoroso-cortés como actantes de una proposición. El poeta, sujeto de la enunciación y al tiempo sujeto (agente) del enunciado, constituye, como 
ya hemos visto en L. T. T. L.. la condición imprescindible desde la que queda definida la lírica amorosa en la tradición europea postrovadoresca y postpetrarquista. Esta peculiaridad de la expresión lírica amorosa contribuía sin duda a hacer de la poesía amorosa la temática lírica por excelencia en la tradición poética europea. La inserción de otros temas, como el conmemorativo, o de otras modalidades expresivas, aun dentro de la temática amorosa, como la narrativo-objetiva -que veremos en Lope, y que disociaba al poeta como sujeto de la enunciación y al personaje como sujeto del enunciado-, acabaron ganando sólo consistencia como productos líricos en la medida en que la impresión textual externa, estrófica, y las similaridades elocutivo-retóricas, como el tipo de lenguaje. fueron enturbiando la originaria conciencia lírica fundamentalmente centrada en la peculiaridad expresivo-actancial del poeta. El poeta lírico clásico, por tanto, tenía conciencia muy marcada de que las exigencias del género que cultivaba le imponian la producción de un tipo de texto simtomaitico-expositivo en el que él mismo desempeñara el papel de agente.

Sin embargo, respetando la estructura de la fórınula básica de la poesía amorosa, el poeta disponía de una alternativa textual, que le permitía sin duda enriquecer y diversificar el tipo de textos producidos, el cual estaba sometido, como hemos ido descubriendo en los trabajos de esta serie, a la presión de una cánonística y una práctica, conscientes o inconscientes, extremadamente fijas y limitadas, al menos en lo que a la dimensión macrotextual de los sonetos se refiere. La alternativa consistía en enfatizar, a través del modo de la expresión, el papel de los actantes término y confidente. Conociendo la definición tradicional de la lírica como expresión del yo del poeta, poco informativa resulta nuestra indicación precedente de que el modo por excelencia de la expresión líricoamorosa clásica es el sintomático-expositivo. Sin embargo, por esta misma razón, ya es más ilustrativo constatar que, en el caso de Lópe de Vega. Iós textos con estructura apelativia son incluso más numerosos en verdad que los sintomáticos (76 frente a 54 en el libro de las Rimas).

Lope frecuenta, pues, con evidente gusto el recurso del énfasis expresivo-apelativo. Con frecuencia dirige sus palabras de queja o de galantería positiva a la dama, a alguna parte de ella. como ojos, etc.; o incluso imposta su propia expresión sobre si mismo - ya como.tal persona, ya a través de fórmulas indirectas como apelación a sus propios sentimientos, al Amor como universal abstracto, a sus escritos y billetes galantes, etc.- Por último la apelación se realiza con gran regularidad en la persona del confidente. La importancia temática de este elemento textual en la lírica amonosa clásica la hemos puesto de relieve desde 
nuestro trabajo inicial en este campo -L. T. T. L.- A . Ahora hemos de referirnos nuevamente a él, en el caso de Lope de Vega, para indicar su positiva importancia como elemento determinante de la naturaleza sintáctica macrocomponencial del texto. Sin embargo, diferimos la discusión de la problemática siempre relevante de su consideración concreta como categoría i sintáctico-textual, o más general como categoría temático-textual (es decir, en nuestro actual entendimiento funcional del tema, sintáctico-semántico), al apartado correspondiente dentro de nuestra actual propuesta de modificaciones al esquema inicial provisional en L. T. T. L.

Por último, hemos de destacar una peculiaridad muy marcada en el caso de Lope de Vega. Se trata de la inclusión como sonetos líricos de verdaderos textos narrativos, realizada no excepcionalmente como en el caso de otros creadores contemporáneos, sino sistemáticamente. En unos casos, tales textos narrativos cumplen en último término la función básica lírica sintomática, en la medida en que, o bien incluyen una referencia explícita al propio caso amoroso del poeta, o bien se configura la narración como soporte de una moraleja universal, de contenido amoroso, que bien podemos considerar también relativa al propio poeta, a través de una presuposición pragmática a la que conduce su estructura general, temática y sintáctica. De ambas formas, el contenido narrado funciona en el cuerpo del texto como una especie de término de símil al que se referiría el propio caso o situación amorosa. Otros textos, sin embargo, no escasos -diez en total-, cumplirian una función puramente representativa, en la medida en que se trata de historias de amores de personajes ajenos al mundo del poeta, narrados directamente sin incidencia alguna del caso del narrador ni marca explícita de apelación. Como es evidente, tales textos no son propiamente lírico-amorosos, pues, si bien está presente en ellos la base semántica amorosa, falta la estructura actancial básica sintáctico-semántica, que identifica el sujeto de la enunciación y del enunciado, produciéndose así esa ausencia de función sintomática que los desnaturaliza como textos líricos confiriéndoles, en consecuencia, naturaleza narrativo-representativa.

\subsection{Textos en función apelativa}

1.1.1. La dama. Los sonetos de apelación a la dama cubren por lo común un grupo muy restringido de contenidos temáticos, tal como los expusimos en nuestro trabajo L. T. T. L. Se trata de quejas, en el caso menos frecuente, y de proclamación general de amor, sonetos por excelencia de canto en el caso más común. Sin embargo, la referencia explí- 
cita apelativa a la dama configura temáticamente el discurso de estos sonetos como textos particularmente centrados en su propia estructura sintáctico-semántica. Es decir, lo que destaca inmediatamente en tales textos es la estructura movida, ingeniosa -conceptuosa- del flujo mismo del discurso textual, conducente a lograr inmediatamente en la dama, o quizá en último término en el lector, un efecto de sorpresa con la inesperada solución del discurso, tal como se producía en general a través del metaforismo catacrético, abundante en el conceptismo contemporáneo de Lope. De ahí que la inmensa mayoria de los textos censados por nosotros como de apelación a la dama conllevan la nota temática en L. T. T. I. de galanteo, discursivo o requiebro "bis.

El número de sonetos en apelación a la dama que no registran estrictamente la estructura de galanteo, sino cualquier otra, es, desde luego, mucho más reducido que el del texto tipo, lo que viene a marcar la importancia del factor estructural sintáctico en el terminal temático galanteo de nuestro esquema inicial. Entre los textos que no quedarian absolutamente incluidos en la modalidad general hay que descontar los casos, pocos -3 y 164-, en que la apelación se resuetve en un simple vocativo sin más incidencia de la dama en la estructura textual sintáctico-semántica del soneto. El tono de gracejo requebrante desaparece también, aunque no siempre totalmente, en los sonetos con marcada estructura narrativa, como el 168, donde se describe dentro de la apelación el caso excepcional amoroso del paso cruzado del amor a la indiferencia entre la dama y el galán, o bien el 184, donde la atención

11 bis Véase, por ejemplo, la siguiente relación de sonetos. todos los cuales registran estrictamente la estructura de gatanteo a que hacemos referencia en el texto: 32, "Si gasta el mar la endurecida roca»; 34, «Deste mi grande amor y el poco suyo"; 41, «Hermosos ojos, yo juré que habia»; 43. "(jos, por quien llamé dichoso) al dia”; 44, "Que otras veces ané negar no puedo»; 53, «Estando ausente de tus bellos ojos»; 57, «Silvio en el monte vio con lazs) estrechom; 59. "Al sol (que os mira. por miraros miron; 60. "Quien dice que en mujeres no hay firmera"; 62, "En las riberas del egipcio Nilom; 65. "Clarinda. Amor se corre, y no consiente»; 69, "Si todas las espadas que diez años»; 7!. "Desde esta playa inútil, y desierto»; 72, "Deja los judiciarios lisonjeros»; 81, "L.ıxinda, yo me siento arder, y sigo»; 88. "Si estáis enfermos, dukes ojos claros"; 96, "Mis recatos, mis ojos, mis pasiones"; 99. "Perderá de los cielos la belleza"; 105, "Ojos de mayor gracia y hermosura"; 106. "La noche viene descogiendo el velon; 108. "Amor por ese sol divino jura"; 125, "Mano amorosa, a quien Amor solía”; 133, "Ya no quiero más bien que sólo amaros"; 140, * Estas postreras lágrimas te ofrezco»; 143, "Si al espejo, Lucinda, para agravios»; 146. "Luxinda. el alma, pluma y lengua mía*; 152, "Hermosa Parca, blandamente fiera*; 153, "Si la más dura encina que ha nacidow, y 156, „Si para comparar'vuestra hermosura». A propósito del juego actancial en la estructura del texto del soneto, véase nuestro reciente articulo: Estatuto del personaje en el soneto amoraso del Siglo de Oro, en "Lexis", IV, 1, 1980, pp. 61-75. 
básica del texto se desplaza a la narración de la peripecia del llanto de la dama que bebió el poeta; y, claro está, sería mucho más justificado el caso del soneto 180 , de narración pura con varón amante en tercera persona por lo que respecta a las explicaciones entre el poeta no amante y la dama en coloquio absolutamente extraamoroso.

Obsérvese que la desaparición del rasgo sintáctico-semántico de galanteo va asociada en la mayoría de los casos a sonetos de condición amorosa no estrictamente tal. El requiebro supone siempre canto, raramente quejas puras, cuando mucho quejas superadas. De ahí que donde tal situación no se ofrece, como en el caso de los sonetos excepcionales a los que estamos aludiendo, por más acuciante y violenta que sea la apelación, no se resuelve con la ritual fineza del galanteo; sería el caso del poema 171: «Llamas y huyes; quieres y aborreces», en el que más que la queja comparece la conminación amenazante en términos que suponen en el poeta una situación antitópica de independencia. Véase el último texto: «Silvia, o te agrado, o no, si no despide; / si agrado, no consultes mi amor tanto: / que amor no es encomienda, sino gusto». En estos mismos tipos, entre quejoso y conminatorio y de poeta no amante, situaríamos los casos de apelación en los sonetos de Lope de carpe diem: el 14, *Vierte racimos de gloriosa palma», o el 25, "Antes que el cierzo de la edad ligera». En el caso contrario situaríamos otros sonetos que, pese a su condición de apelación explícita, no se desenvuelven en la estructura sintáctica del requiebro, porque cuentan en su tema con una estructura pragmático-objetiva que ya por sí misma constituye una muestra de esa suerte de retorcimiento y agudeza conceptual que implica siempre el soneto; sería el caso de algunos textos de peripecia como el 189, o sobre todo el 29, a una dama que le echó tierra a los ojos. Por último, si decíamos que la apelación galante suponía más el canto que la queja, en los textos donde el canto es tan rotundo que se trata del simple ofrecimiento total, confesión o proclamación amorosa, la apelación se resuelve bajo fórmulas sintácticas inmediatas y directas, sin el jugueteo y la coquetería que traduce la estructura sintáctico-semántica de los sonetos de galanteo. Próxima, pues, semánticamente al galanteo, la proclamación supone un caso diametralmente opuesto de estructura textual sintáctica $^{12}$.

Entre las peculiaridades más sobresalientes de este tipo de textos apelativos cabría señalar la de que, a diferencia de los de confidente, la

\footnotetext{
12 Véanse los sonetos correspondientes a nuestra afirmación: 83, "Yo no espero la flota, ni importuno»; 95, "Montes se ensalzan y dilatan ríos»; 113, «Desde que viene la rosadą aurora»; 117, «Rompa con dukes números el canto»; 155, «Belleza singular, ingenio raro».
} 
presencia de la dama es por lo general persistente y explicita a todo $k$ ) largo del soneto, a través de fórmulas verbales y pronominales de referencia directa. Sólo en algunos casos aislados, como el del soneto 44. "Que otras veces amé negar no puedo». las referencias verbales y los vocativos escasean. Por último, no es infrecuente que la apelación a la dama se haga a través de la referencia preferente, 0 incluso exclusiva. a sus ojos - sonetos 41, 43, 53, 59, 88, 105, 106, 108- peculiaridad tanto más singular cuanto que en Lope, a diferencia sobre todo de Herrera, no se dan los sonetos descriptivos que hemos denominado en $I$. ' $T$. ' $I$. I. de retrato, bajo ninguna de sus modalidades.

1.1.2. El confidente. De'los ciento cuarenta y dos textos de nuesträi muestra, pertenecen a esta categoría temática veintiún sonetos. Es decir, se produce aproximadamente la misma frecuencia relatival que hemos observado en el conjunto general del acorpus» de L.. T. T. L... entre los sonetos de Garcilaso, Herrera, Quevedos y (iongora. Fin el cass) de lope. por lo demás, el confidente suele estar largamente presente en la estruxtura del texto. Quiero decir, que el confidente es más que un puro vocativo, como sucede en otros poetas. En Lope sólo seis veces es aludido el confidente como voxativo-refuer\%o enfático en textos expositivo-narrativos; se trata de ks sonetos 50, 160) y 185 a un Marcio y Meliso figurados, aludidos en vocativo dos veces en el primero y una sola vez en el segundo y tercero; el soneto 89 a don Félix Arias Girón. que aparte del título sólo aparece mencionado como vocativo en el primer verso: «Don Félix, si al amor le pintan ciego», y análogamente los sonetos 10 y 98 a don Luis de Vargas. En todos los demás casos el confidente, personal o inanimado, cubre una importante parcela de la macroestructura sintáctico-semántica de los textos, que nos obliga a considerarlo como clase temática especifica, y no sólo como entidad sintáctica.

Así por ejemplo, el soneto 115 a Juan Bautista Labaña está construido como una conversación sobre símil amoroso)-astronómico en el entendimiento de la ciencia del confidente. En el 66, Lupercio Leonardo de Argensola aparece en función de corresponsal literario de Lope en un soneto cuya estructura temática fundamental es la escritura de la pasión amorosa o su interrupción. El soneto 82, «Al serenísimo Archiduque (Alberto)», se construye temáticamente como promesa de canto a las empresas militares del confidente, una vez superada la pasión amorosa obsesiva. El contador don Gaspar de Barrionuevo, confidente en el soneto 151, es intermediario con la dama enferma al que en cada estrofa se dirige Lope en imperativo - decidle / advertidle / advertidle / decidle»- Análoga a ésta, aunque con tema distinto, es la fórmula de 
presencia del confidente -n este caso oponente- que aparece bajo imperativo en cada estrofa en el conocido soneto 188, «Suelta mi manso. mayoral extrañow. En el soneto 92 dedicado al escritor y amigo Pedro Liñán de Riaza, éste cumple el «rol* temático de enamorado en causa más segura; análogamente don Melchor de Prada en el soneto 130, del que incluso se transparenta una completa historia de suicidio frustrado por amor; anécdota que llena el cuerpo del texto, como la del caballero *llevando a su dama a enterrar él mismo* del soneto 28. Por último, el soneto 192 presenta el caso de un pintor *enamorado de una dama cuyo retrato hacía*, confidente innominado, con quien el poeta establece el diálogo temático consabido en torno a la imposibilidad de representar la hermosura. Casos todos, como puede verse, en los que es preciso mantener el confidente como estructura temática fundamental del texto del soneto. Por tanto, en la necesaria revisión de nuestro esquema inicial de L. T. T. L., por lo que se refiere al confidente, los casos como los mencionados deberán permanecer constatados como estructuras textuales básicas temático-semánticas; pero debiendo quizá eliminar sólo del elenco de textos allí establecidos los sonetos con confidente-inciso, simple vocativo; reconduciéndolos, en tal caso, a las casillas tipológicas de sus correspondientes contenidos temático-semánticos: queja, sufrimiento, canto, etc. 12 bis.

Trece son los ejemplos de confidente-símil, es decir, no humano, que Lope nos presenta; casi todos ellos, como los de confidente-humano, con importante incidencia temático-semántica. Así: el 119 a unas piedras y puertas reflejo de la dureza amorosa de la dama, el 138 a un monte, nieve y puerto de montaña con idéntica incidencia temático-textual que el anterior en toda la macroestructura. Montes y céfiro son confidentes activos transmisores de mensaje en los sonetos 37 y 135 . El mito Apolo-sol y su juego tópico de implicación en el amor, si se para a contemplar la dama, es el tema del soneto 36 . Y, por último, el conocido confidente-símil río con las complejas implicaciones textuales que le hacen desempeñar un papel actancial siempre decisivo en la estructura temático-semántica del texto, aparece en los sonetos 8, 9, 12, 154 y 183. Tampoco estos casos de confidente-símil representados por Lope de Vega, nos obligaron a plantearnos su exclusión como categoría temática sintáctico-semántica de nuestro esquema inicial básico. Si acaso, el confidente meramente circunstante «álamos» en el soneto 124: «Blancos y verdes álamos, un día», que no resta validez a su carácter primario sintomático-narrativo.

12 bis Tarea ya resuelta en nuestros últimos trabajos aún inéditos, y adelantada en nuestro articulo A Text-typology of the Classical Sonnets, cit. 
1.1.3. Apelaciones rarias: Amor. El popta mismo. Constituye el grupo más restringido de textos apelativos - trece en total-y en él se pueden establecer nitidamente dos sectores. La apelación al Amor, como universal abstracto está en Lope vinculada exclusivamente a la queja en estos sonetos apelativos - números 60. 69. 83, 102 y 108-. Por otra parte, Lope adopta la modalidad de expresión apelativa también en casos de sonetos de contenido temático en principio claramente sintomático. En tales textos se produce un desdoblamiento entre la persona del poeta y alguna de sus potencias o productos con intervención en la anécdota temática amorosa. Así: los "pensamientos tristes" del soneto 42, las "tristezas" en el soneto 97, las ilusiones y el desengaño en el 101 o el 119. el propio sufrimiento en el 136. los ojos y el corazón objetivados en el 173; o incluso los propios papeles, en blanco o rotos, en los sonetos 70 y 190; todos son objeto de tematización central y apelación explícita y extensa en los sonetos mencionados.

\subsection{Textos en función sintomática}

1.2.1 Como ya hemos tenido ocasión de advertir, puede considerarse una verdadera propuesta tautológica hablar de expresión lírica -y sobre todo, históricamente, de lírica amorosa- en función sintomática. La lírica, como bien es sabido, tematiza por definición la expresión del propio yo del poeta emisor, y se constituye para el receptor en fuente de experiencia sobre el yo propio o sobre el ser del mundo y de la vida, sólo a través de las propias declaraciones observadas y como sorprendidas en el emisor. En tal sentido, todo texto lírico es en principio un texto-síntoma, por definición. Pero, aceptado este hecho general válido sin duda y casi sin excepción en los textos amorosos de Lope de Vega que examinamos en este trabajo, en nuestra observación sintáctica de los sonetos hemos primado a la hora de la clasificación tipológica cualquier rasgo sintáctico especial, de tipo expositivo-apelativo o narrativoobjetivo, fundándonos en el convencimiento pragmático-semántico de que, en último término, todo texto amoroso es expresión de los propios sentimientos y vivencias del poeta, doble sujeto agente de la enunciación y del enunciado.

Por lo demás, en la mayoría de los casos de la apelación en sonetos de Lope, según hemos visto, el peso semántico del «rol» de la dama apelada -y mucho más el del confidente, cuando no es un puro vocativo- permite, sin abusos considerar preponderantemente, sobre la presencia misma de la propia manifestación sintomática del sujeto emisor, su incidencia como elemento tematizado en la estructura general del 
texto, tanto en el nivel macrocomponencial profundo como en la dimensión cuantificable y medible de su manifestación lineal terminal.

Aún más fuertes son las razones para tipologizar aparte de la función sintomática el conjunto de sonetos de Lope - de naturaleza excepcional, sea bien claro, tanto temática como macroconstructiva-, que se constituyen en función representativa mediante una expresión textual de tipo narrativo. Si el propio caso amoroso de Lope puede transparentarse en ellos, como veremos a continuación, en virtud de inferencias pragmáticas diversas, no cabe duda de que, formal e inmanentemente, no constituyen textos formulados desde un yo presente y explícito, lo que les conferiría, sin duda, la condición sintomática. Por otra parte, no conviene olvidar que en la misma formulación lingüística de las funciones del lenguaje, ni Bühler ni Jakobson pretendieron afirmar la exclusividad de ninguna de ellas en cualquier acto lingüístico real mínimamente complejo, y mucho menos en un acto expresivo tan complejo como el texto de un soneto. Lo que ellos afirmaron sobre las funciones, y que aquí se corrobora, es que en todo acto de habla, o quizás más adecuadamente bajo cada una de las perspectivas practicables en un acto de habla - la del emisor, la del receptor apelado y la del espectador distante-prima una de las funciones sobre las demás, que por lo común se presenta simultánea y solidariamente con la función primaria evidenciada. Análogamente, en nuestro caso, la función sintomática no se halla ausente de ningún texto lírico amoroso, siendo su menor o mayor grado de evidencia explícita entre las otras dos, singularmente la apelativa, lo que ha justificado en cada texto nuestra decisión clasificatoria.

1.2.2. Como en el caso de la apelación a la dama, también aquí là voz del poeta elevada a síntoma de su sufrimiento se ve ligada con sorprendente frecuencia a una sola temática: la del desengaño o la desilusión. Una vez más podemos constatar, en consecuencia, la estrecha relación que existe entre sintaxis y semántica, entre la construcción, o sea el molde expresivo textual elegido consciente o inconscientemente por el poeta, y el contenido temático convocado. Sin arrojarnos a conjeturas de precedencia, resulta evidente, por casos como el que consideramos, que en el ánimo del creador artístico son casi indestructibles los lazos de costumbre que le ligan con la tradición. El poema se gesta quizá como una imagen auditiva, como sinfonía textual, acústica y hasta visual de conjunto, y por fuerza de costumbre la melodía, evocada desde la memoria acústica de la tradición, convoca un determinado tema, su tema, de manera casi automática. Si queremos imaginarlo a la inversa -quizá ambos sentidos sean posibles en este itinerario, vinculado el proceso de hábitos y peculiaridades individuales -l resultado para 
nuestro caso sería idéntico: un determinado contenido semántico convocaría necesariamente una determinada estructura sintáctica, siguiendo leyes de asociación, quizá vinculadas por razones de necesidad «en la cosa* a la naturaleza cenestésico-intelectual del acto expresivo. Hasta aquí podemos testificar que dicho proceso de selección recíproca sintáctico-semántica se cumple con elevado grado de invariabilidad para casos de asociación de estructuras muy globales: apelación a la damagalanteo, o expresión sintomática-engaño/desengaño. Pero inmediatamente veremos también cómo pueden observarse regularidades sorprendentes en el caso de solidaridades textuales sintáctico-semánticas más restringidas y concretas. Es decir, entre determinadas modalidades de construcción textual -en especial aquéllas muy marcadas, como por ejemplo las que denominamos *antidistributivas" - y determinadas representaciones semánticas; constituyéndose de este modo un conglomerado significante de sentido por encima de cualquier prejuicio compartimental sintáctico y semántico, para el que propondríamos la designación de tema, quizá en una acepción más consciente y precisa -a la vez más amplia y restringida- de la que suele adquirir generalmente en su empleo común en la Poética y la Crítica literaria actuales.

Como ya hemos anticipado, la representación semántica convocada regularmente a través de las formas sintácticas sintomático-textuales más depuradas es la del desencanto, la desilusión. Se constituye así ese proceso temático, fundamental en la sistemática poética del amor cortés, que intuíamos ya, al menos en su vertiente semántico-temática, en nuestra primera elaboración provisional de esta teoría en L. T. T. L. En términos cuantitativos - bajo la denominación genérica engaño-desengaño vinculada a la rama de quejas del poeta a sí mismo-, frente a los veinticinco sonetos sintomáticos de Lope que figuran en nuestra muestra con el contenido temático más variado - aunque, como veremos, tampoco en general absolutamente desconectados en la lógica semántica del tema tópico del desengaño- son dieciocho los textos de esta modalidad sintáctico-semántica sintomática que comportan, como rasgo temático central o marginal, el proceso engaño-desengaño.

1.2.3. Expresión pura del tema la constituyen casos como el del soneto 2 «Cuando imagino de mis breves días». El 5, donde se tematiza narrativamente el engañoso ejemplo de la primera boda de Jacob con Lía, explícitamente aplicado al propio caso bajo la perspectiva del desengaño en el primer terceto: "Triste de mí, sin límite que mida/lo que un engaño al sufrimiento cuesta/y sin remedio que el agravio pida». También bajo estructura de símil, de paisaje en este caso, el desengaño despechado se expresa de modo central en el soneto 7: «Estos los sauces 
son y ésta la fuente» El propio engaño desdoblado por potencias, imaginación vs. voluntad, se descubre también en diferentes textos, si ijen las peculiaridades semánticas del planteamiento antitópico del amor cortés en Lope de Vega ofrecen muestras muy curiosas y especiales en tal sentido, bordeando los límites estructurales últimos del tópico, como en el soneto 23, "Pruebo a engañar mi loco pensamiento", donde en realidad sólo se mantiene la estructura formal tópica engañodesengaño ${ }^{13}$. En este mismo sentido del desdoblamiento propio en el juego de potencias se inscriben los sonetos de estructura sintácticosemántica sintomática: 40, «Mis pasos engañados hasta ahora* con el tema engaño-desengaño (razón vs. voluntad) como rasgo central, y 161: "Cual engañado niño que contento", como rasgo marginal. Al tipo común de representación semántica del desengaño corresponde centralmente el soneto 182, «Fingido amigo, en las lisonjas tierno». Así como un grupo numeroso de sonetos con el tema en rasgo marginal: 4, «Era la alegre víspera del día»; 19, «Pasando un valle oscuro al fin del día»; 27, «Bien fue de acero y bronce aquel primero", y 33 titulado "A un loco favorecido de una dama». El tema básico, como rasgo central, aparece igualmente en sonetos con estructura de símil, como el 21 , con el tema de Midas, curioso porque constituye uno de los casos de más manifiesta transgresión semántica del código del amor cortés, ya que el desengaño $\longrightarrow$ mejor la saciedad-es consecuencia del logro del favor amoroso por parte del poeta-amante, o el 52, uno de los sonetos a Elena Osorio bajo el símil de Troya arruinada. El soneto 98 es igualmente interesante, porque constituye uno de los casos de expresión narrativa-dramatizada, en que el poeta aparece convocado en la disputa entre el Amor y el Tiempo - con el tan lopesco tema de la ausencia por medio- para corroborar y ejemplificar el desengaño, llevado incluso a términos de

${ }^{13}$ Considérese al respecto este curioso texto de Lope de Vega, soneto 23, pp. 36-37:

Pruebo a engañar mi loco pensamiento con la esperanza de mi bien perdido, mostrándole, en mil nubes escondido. un átomo no más de algún contento.

Mas él, que sabe bien que cuanto intento es apariencia de placer fingido, se espanta de que, estando al álma asido, le engañe con fingir lo que no siento.

Voile llevando de uno en mil engaños, como si yo sin él tratase dellos, siendo el mayor testigo de mis daños.

Pero siendo forzoso padecellos, joh quién nunca pensase en desengaños, o se desengañase de tenellos! 
transgresión del código poético del amor cortés: «Pidió un testigo Amor. trújome el tiempo/yo juré que en una hora, habiendo agravio,/no sóko sé olvidar, pero aborrezco». Y finalmente en términos absolutamente opuestos a los del soneto anterior, el tipo de desengaño por conciencia del propio menosprecio que se registra en el soneto 175, «Deseando estar dentro de vos propian.

Los temas de los sonetos sintomáticos no inmediatamente vinculados al referido de engaño-desengaño, no son tampoco semánticamente tan distantes que no resulte posible, a su vez, establecer las conexiones lógicas correspondientes. Por lo demás, la semejanza estructural semántica con el tema del desengaño.de alguno de los tipos más frecuentados resulta evidente: por ejemplo, la expresión de celos o el desengaño y definición del amor a través de textos unisentenciales en antidistribución enfática es quizá el tipo más frecuente de los sonetos que cumplen esta característica constructivo-semántica de la expresión sintomática. Recordemos entre los de celos, el soneto $56^{14}$, o el 134, «Halló Baco la parra provechosa», el 148, «De Cupido y Lucinda», o, en fin, el 146 «Circe, que de hombre en piedra me transforma”. Entre ks aludidos de definición del amor enfática, en términos sintáctico-textuales de antidistribución, recordemos el 126, quizá uno de los más famosos de Iope. que comienza «Desmayarse, atreverse, estar furioso», o también el 61, *Ir y quedarse, y con quedar partirse". La expresión enfática recorre también el tema de muerte deseada, soneto 78, ausencia 75, y otros casos variados de expresión vehemente de quejas o sufrimiento: 76,149 y 170. También se registra, obviamente, el uso de la expresión sintomática en textos de vehemencia positiva como proclamación o canto, soneto 123 , «Cayó la Troya de mi alma en tierra»; soneto 29, «Fue Troya desdichada, y fue famosa»; 185, "Melisn. Amor no es calidad, ni elige»; 191, «Es la

is Consúltese este texto como eloxuente muestra. wneto :56, p. 5(j:

\footnotetext{
Que eternamente las cuarenta y nucve pretendan agotar el lagon Averno: que Tántaks del agua y árbol tiermo nunca el cristal ni las manzanas prikebe:

que sufra el cursu (jue los cjes mucve de su rueda Ixión, por tiempos eterno; que Sísifo, llorando en el infierno. el duro canto por el monte lleve.

que pague Promete(s el hx(o) aviso de ser ladrón que de la divina llama en el Cáucaso, que sus brazos liga; terribles penas son, mas de improviso ver otro amante en braxos de su dama, si son mayores, quien lo vins lo diga.
} 
mujer del hombre lo más bueno», y muchos otros: 4, 6, 13, 110, etc. Registrándose animados casos de significación de alguna peripecia, en sonetos como el 158, titulado *A una dama que se limpiaba los dientes*, donde el énfasis sintomático de la ponderación se sobrepone a la condición en principio preferentemente apelativa del texto; u otros varios: 26 , 68 y 148.

\subsection{Textos en función representativa}

1.3.1. Como ya hemos indicado en distintos lugares de este trabajo, la representación supone en principio el abandono de la forma lírica; su modalidad expresiva es la narrativa, con la presencia del poeta absolutamente eliminada, dejando paso al juego de las terceras personas. En el apartado precedente hemos registrado diferentes casos de narración en textos de función sintomática, lo cual es posible bien por constituirse el poeta mismo en uno de los personajes de la narración, bien porque el contenido semántico de aquélla se proyecta explícitamente sobre el propio caso del poeta. Obviamente, la fórmula expresiva de la representación, que en sí es relativamente excepcional dentro de nuestra tradición lírica, se asocia regularmente con un contenido temático también excepcional, los amores ajenos.

Obviamente, si los textos en que predomina la función representativa, suelen adoptar la narrativa como forma de expresión, no quiere decirse sin embargo que ambos conceptos sean sinónimos, ni siquiera que exista entre ellos una interdependencia exclusiva. Por el contrario, la narración. puede darse en textos sintomáticos y hasta teóricamente en sonetos apelativos (véase en los cuadros del apéndice la incidencia de narración en sonetos sintomáticos). La característica de la narración frente a la exposición lírica la determina la presencia del factor tiempo is. El soneto, al no ser imitación de acciones sino exposición de un concepto, prescinde

is La reflexión sobre esta importante vertiente de nuestro esquema nos la ha brindados una amabilísima sugerencia personal de nuestro admirado amigo el profesor Harald Weinrich, tras la consideración de nuestra teoría en una conferencia en el Instituto de Lingüística Románica de la Universidad de Munich. Sin duda que nuestra reflexión actual sobre la incidencia del factor temporal en la construcción del texto del soneto clásico, así como la incorporación y reajuste de nuestros esquemas anteriores desde tal parámetro en la formulación definitiva de esta teoría, serán enormemente tributarias al conjunto de aportaciones de Weinrich sobre la dinámica temporal del texto, patentes ya desde su primera gran aportación de conjunto, Tempus, Stuttgart, Kolhammer, 1971. Desde la finalización de este artículo al momento de corregir pruebas hemos completado el estudio temático del tiempo englobado en la problemática del circunstante temático. Un anticipo de su representación esquemática lo hemos of recido ya en $A$ Text-typology of the classical sonnets, cit. Tiempo y texto constituyen quizá la más fecunda forma de encuesta más 
teóricamente y por definición, como forma genuinamente lírica, de la dimensión temporal; sin embargo, en la práctica, son muchos los textos clásicos en los que la exposición se centra en acontecimientos seriados en sucesión temporal; en tales casos, la exposición se convierte en narración.

En todos nuestros trabajos hasta el presente, desde L. T. T. L., nos hemos mantenido dentro de una concepción preferentemente sintomático-expositiva del soneto como forma lírica. Sin embargo, somos conscientes de la importancia de la. incidencia narrativa en muchos textos. No sólo en los excepcionales, tales como el 168, por varios conceptos aludidos en este estudio, donde se tematiza el transcurso del tiempo en las peripecias del propio amor: "Cuando vos me seguisteis, iba huyendo; / huis agora vos cuando yo os sigo»; sino en un buen número de textos de tema tópico integrados por nosotros en nuestro esquema de L. T. T. L. Pensemos, por ejemplo, en los que hemos denominado en distintas ocasiones sonetos de itinerario, incorporados al esquema regularmente como textos de expresión metafórica, generalmente de la queja. (En los apartados de paisaje, de L. T. T. L., que más adecuadamente deberíamos haber denominado de sentimiento de la Naturaleza o con otras expresiones semejantes.)

El caso del tema de itinerario lo contemplamos ahora, desde nuestra reflexión actual, como un típico ejemplo de tematización temporal, análogo, y quizá más generalizado, a otros muchos textos en los que se tematiza bajo distintas fórmulas concretas la incidencia temporal como proceso narrativo. Por ejemplo, los casos de conmemoración de fechas, de declaración de aniversarios en la devoción amorosa, los de reincidencia amorosa, los de proclamación de amor permanente o constante más allá de la muerte, etc.

Evidentemente, la incidencia del factor temporal $-y$ con él de la forma narrativa - en la estructura de los sonetos es una de las perspectivas más urgentes que hemos de tener en cuenta en la elaboración progresiva de este conjunto teórico. Abordaremos la empresa en próximos trabajos, ya sea como tematización explícita independiente, ya - o que es más probable - tratando de asumir la variable tiempo dentro de nuestra remodelación inmediata del esquema de $L$. T. T. L.

En este trabajo no nos planteamos inicialmente el problema de distinguir entre narración y representación; diferencia sólo evidenciada

recientemente operada en la actividad, pionera primero y siempre directriz. de este humanista moderno, tanto en sus rigurosas observaciones lingüisticas sobre los textos puramente comunicativos, como en sus profundas constataciones, dominadas por una elegante sensibilidad, sobre el texw artistico. 
cuando ya estaba desarrollado totalmente el análisis de materiales. Por ello, los límites en nuestro análisis de algunos textos quedan quizá algo desdibujados. No obstante, en nuestra reflexión consciente en una última lectura, creemos que en líneas generales la distinción resulta bien establecida, en especial merced a la presencia de textos narrativos en la modalidad sintomática. La práctica ausencia de textos narrativos en las casillas de apelación se debe no sólo a un fenómeno de inadvertencia analítica. Ciertamente que con la apelación coinciden en muchos textos no sólo la forma expositiva, sino la incidencia temporal-narrativa. Sin embargo, como frecuentemente hemos advertido, para nosotros la función de apelación en los textos no marca un hecho de exclusión de las otras funciones y de sus modos de expresión privativos; sino a través de la catalogación como textos apelativos pretendemos establecer el primado constructivo de las fórmulas de énfasis apelativo en la estructura de la argumentación textual de tales textos.

No obstante, insistimos en la necesidad de incorporar la reflexión sobre el factor tiempo en la estructura macrotextual, temática y constructiva de los sonetos clásicos, que para el desarrollo de nuestra teoría tipológica sentimos con urgente perentoriedad. Será necesario muy probablemente no sólo una reelaboración -con redistribución e incluso cambio de denominaciones- temática de los materiales de L. T. T. L. ${ }^{15 b i s,}$ sino quizá también un reexamen de la línea de separación teórica entre narración y exposición en las decisiones de catalogación tipológica que han presidido nuestros análisis en este mismo trabajo, contando como elemento básico de discriminación con la presencia del tiempo objetivo (narrativo), centrado en el enunciado, frente al tiempo de expresión (expositivo), centrado en la enunciación. La alusión a ambas modalidades queda a veces recogida ya en nuestro texto actual. En ocasiones hemos distinguido entre narración objetiva, como sinónimo explícito de la modalidad de expresión narrativa en función representativa, es decir, con sujeto en tercera persona distinto del poeta como sujeto de la enunciación, y simple narración o narración subjetiva, con lo que se designa el tipo de narración en función sintomática, típicamente lírica, en la que el sujeto de la enunciación es al mismo tiempo sujeto del enunciado.

Volviendo al tema de la narración representativa en Lope, el caso no era ciertamente nuevo en nuestras letras, ya Garcilaso lo había planteado precisamente en el tema de Leandro, en el famoso soneto 29, que

15 bis Un anticipo ya bastante completo de nuestros trabajos en tal sentido, posteriores a la redacción de este artículo, lo hemos of recido en nuestra síntesis, $A$ Text-Typology of the Classical Sonnets, en «Poetics», 8 (1979), pp. 435-458. Consúltense especialmente la figura 1 $v$ las pp. 445-446. 
repetiria Quevedo con menos fortuna en el que comienza "Flota de cuantos ravos y centellas". Góngora. a su vez, celebró la consumación matrimonial de Felipe $I V$ y la reina Isabel en dos elegantísimos sonetos, "Duke arroruelo de la nieve fría" " "Peinaba al sol Belisa sus cabellos". Sin embargo. Lope de l'ega también supo constituirse en singular excepción en este punto. Dieriséis sonetos de contenido amoroso con este tipo de construcción narrativa se registran en las Rimas. Es decir, más de un dies por ciento en el total de las composiciones.

No entramos ahora en la consideración de la excepcionalidad temática de estos sonetos. Aqui nos referiremos exclusiamènte a su peculiaridad sintáctico-expresian y las consecuencias que implica. Usualmente se ha destacado en lope la excepcionalidad e independencia de su genio creador contemplado sólo desde la parcela de su renovación de los géneros dramáticos, tan profiinda que le llevó a ser considerado con justicia como el fundador de una afortunadisima experiencia de teatro nacional. Sin embargo, la atenta observación de las estructuras sintáctico-semánticas de su producción lírica no arroja consideración en modo alguno diferente. Aun cuando éste sea un aspecto de la personalidad artística de Lope como gran genio de la creación mucho más inédito, que sepamos. El talante renovador de Lope de Vega no se restringe, por tanto, al solo género teatral, sino que se extiende -como, lógicamente, no podía ser de otro modo - al conjunto general de su riquísima y miscelánea creación artística.

La genialidad evidente de Lope sé ve corroborada también en su producción lírica a través del mismo cauce que consagró su excepcionalidad como autor dramático: la ruptura con el sistema clásico de preceptos poético-retóricos. Si en el caso del teatro la manifestación más evidente de todo ello fue la desatención de las "unidades", en el de la lírica, y desde nuestra perspectiva concreta actual de la lírica amorosa. lo fue sin duda la desobediencia a la férrea canonística temática del amor cortés, que nuestros trabajos van evidenciando como conjunto de estructuras extremadamente finito. La fórmula de Lope en su teatro como en su poesía amorosa fue muy simple -y para él, por lo demás, absoluta y fatalmente inevitable-: la irrupción de la propia biografía en el dominio topificado de la literatura. Las vivencias personales de Lope y las del ambiente social español tradicional y contemporáneo habian de romper por fuerza los estrechos márgenes de la dramaturgia clásica, que si siempre se supuso férreamente estructurada de modo inmutable por la sintaxis de las unidades, no lo estaba menos - aunque esto sea quizá menos evidente- en cuanto a la selección temática que determinaba la canonistica moral, los usos consagrados por la tradición artística y las 
restricciones mismas de las unidades como esquema sintáctico del texto dramático.

Si la fórmula vital de Lope en el caso de la lírica cristalizó en una poderosa peculiarización de la canonística temática tradicional y sobre todo en la plasmación de las situaciones excepcionales de su propia aventurera biografía que desbordaron tan frecuente $y$ contradictoriamente el esquema tópico del amor cortés, en la dimensión sintáctico-textual quizá el correlato más sorprendente y extremado de la innovación lo constituya esta modalidad expresiva narrativo-representativa. Lo que ella traduce en concreto, digámoslo cuanto antes, es la primordial condición de dramaturgo de Lope de Vega. Los textos que estamos considerando no son sólo textos narrativos, sino más precisamente textos dramáticos, en los que con mayor frecuencia se ofrece incluso la estructura dialogada - la proporción es de diez frente a seis-. La organización dramática del texto es evidente en los sonetos sin diálogo, donde. como veremos en el apartado de la estructura sintáctica macrocomponencial, incluso se descubre la acomodación de estrofas del soneto con la de tres jornadas y conclusión de la obra ${ }^{16}$. Siendo quizás aún más evidente en los casos de diálogo, donde la isodistribución estrófica marca con frecuencia el tránsito de la presentación narrativa en los cuartetos a la acción dramática en el diálogo de los tercetos, como en el soneto 186, a doña Blanca de Borbón, que bien pudiera servir de bosquejo a uno de tantos dramas históricos de Lope ${ }^{17}$

16 Véase el soneto aludido, soneto 18, p. 34:

Píramo triste, que de Tisbe mira teñido en sangre el negro manto, hekise; vuelve a mirar, y sin morir, murióse: esfuérzase a llorar, tiembla y suspira.

Ya llora con piedad y ya con ira; al fin. para que el alma en pay repose. sobre la punta de la espada echóse. y sin partir el alma, el (uerpo expira.

Tisbe vuelve, y le mira apenas cuando arroja el blanco pecho al hierro fuerte. más que de sangre, de piedad desnudo.

Piramo, que su bien mira expirando, diose prisa a morir, y así la muerte juntó los pechos que el Amor no pudo.

17 Véase el texto mencionado, soneto 186, p. 134:

La blanca en el valor, venida a España, y en Francia, y en el mundo, más preciosa, vertiendo hielo, marchitó la rosa de las mejillas, que llorando baña. 


\section{Macroestructura constructiva. Esquemas de argumentación textual}

\subsection{Clases generales}

2.0.1. La clasificación que abordamos en este apartado se refiere a los aspectos sintáctico-distributivos de la construcción textual. Con el aclarador concepto retórico lo denominaríamos apartado de la dispositio macrotextual. Se refiere obviamente al orden en que las varias piezas textuales, las cláusulas, se organizan y colocan en la textura sintáctica del total del soneto. Es éste el dominio textual sintáctico más estrictamente tal, ya que la anteriormente expuesta clasificación por el tipo de función expresiva puede considerarse poderosamente influida por la entidad semántica misma de los actores textuales y por el condicionamiento pragmático del texto como acto complejo de expresión.

Adelantemos, sin embargo, que en este apartado tratamos de establecer una tipología sintáctico-textual, macrocomponencial, a la que denominaremos usualmente de construcción, exclusivamente centrada en los sonetos amorosos de Lope de Vega. No comparable, por tanto, todavia, ni por lo que se refiere al número total de elementos de la muestra, ni a la diversidad de autores encuestados, a nuestra tipología inicial temática de L. T. T. L. Por ello, las constantes organizativas, bastante precisas y bien marcadas por cierto, de la sintaxis textual de Lope de Vega, obedecerán, en principio, a su propia iniciativa personal, sin atenerse, por tanto, a usos tradicionales. El contraste que la temática textual de Lope ofrece respecto a la temática amorosa de otros autores -ya posible tras nuestro establecimiento de una tipología general sobre muestra relativamente extensa en $L$. T. T. L.- nos permite prever ahora nítidamente cómo la radical actitud innovadora de Lope no se centró exclusivamente, como hasta el presente se ha puesto de relieve preponderantemente, en su actividad de dramaturgo, sino antes bien en su condición total de creador literario. Claro está que conviené no olvidar que, en el caso de los distintos géneros, esta tendencia antitópica

Del fuerte Pedro, armado en la campaña. vencido de otro amor, está quejosa: y aunque no la ha de oir. con voz piadosa. movió la lengua propia, en lengua extraña:

"Amor, sangre conforme, estrellas, tiato, faltando todos en mi, pudo hallar modos que amase, y olvidase Pedro ingrato.

"Amor, aborrece; pido, niega en (odo; su sombra adoro, y huvo mi retrato; yo tierna. él fuerte; yo francesa. él godo.. 
del inconformismo renovador del vital Lope se cimentaba sobre estados muy distintos de consolidación de la tradición literaria, en general y sobre todo en el dominio español. Así, un cambio milimétrico en el seno de una tradición artística tan tópicamente estructurada como la de la lírica amorosa puede tener tanto valor sintomático como un distanciamiento mucho más tajante en el caso de la comedia, por ejemplo.

La tipología sintáctica macrotextual bosquejada en este apartado debe ser extendida y contrastada, por tanto, en dos órdenes distintos. En primer lugar, debe ser puesta a prueba sobre el conjunto total de los sonetos de todo tema de Lope de Vega. De lo cual resultará afirmada o negada la independencia de la sintaxis textual respecto a la estructura semántico-temática. En segundo lugar, debe ser contrastada con la sintaxis macrotextual de los sonetos amorosos de otros autores. Así resultará posible establecer si la tipología aquí elaborada para estos sonetos amorosos - extensible o no al conjunto total de sonetos de todo tipo de Lope- responde a unos hábitos de construcción textual relativamente tópicos o constituye, por el contrario, un caso más de afirmación de la independencia creativa de Lope de Vega.

Adelantemos, asimismo, que, refiriéndonos a la macrosintaxis, atenderemos de modo prioritario al establecimiento de grandes clases. Es decir, nos fijaremos más en las coincidencias globales que en las discrepancias de detalle. Estas últimas son siempre posibles, y en último término, en el límite difícilmente establecido entre construcción textual y microsintaxis concreta, todos los sonetos examinados difieren entre sí de tal manera que, como en el caso de la temática, se puede alcanzar obviamente una singularización de cada texto en una clase. Sin embargo, creo que ésta no es mi tarea en este momento, pues lo que abundan en la tradición lingüística y crítico-literaria son los análisis de las singularidades textuales, con ausencia del establecimiento de los parámetros comunes, desde los cuales -y sólo desde ellos- es posible definir no intuitivamente la singularidad lingüística o artística de un texto dado.

2.0.2. El punto de partida inicial que hemos adoptado para esta clasificación es el de la distribución relativa entre argumentación macrotextual y estructura métrico-estrófica del soneto. No se olvide que partimos de una peculiaridad muy importante en el caso de nuestros textos, y es que se trata de textos de dimensión absolutamente idéntica -catorce sintagmas rítmicos de once sílabas-, compartimentados en cláusulas rítmicosintácticas absolutamente prefijadas - dos cuartetos y dos tercetos-. Por si esto fuera poco, la rima juega un papel muy importante a la hora de crear una escisión entre la primera mitad del texto -cuartetos-, de 
rima absolutamente fijada, y la segunda - tercetos-. (on un (ambin) total de consonantes y posibilidad de combinaxión algo más libre. (iomo) regla general, diremos que la estructura métrixa del someto (rea un claro limite entre cuartetos y tercetos, al cual, comos veremms. obedere casi regularmente la organizaxion del max roxomponente sintix.tix(o-se'mántix.) del soneto.

Por consiguiente, la primera gran diferencia observable en la sintaxis maxrotextual del texto soneto es la que se establece entre apuellos cams que respetan y ajustan la referida estructural al limite métriko-rituiko, palra los cuales propxonemos la demominacionn de textos en isodistriburioun

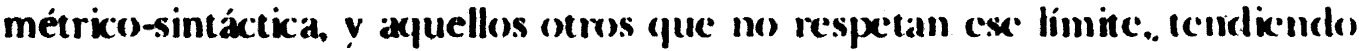
a una más global cohesión textual. limandos las barreras métrikas a baise de encabalgamiento estróficom, para los que proponemos la demominación de textos en antidistribución métrixonestrólica.

\subsection{Antidistribución}

2.1.1. Se trata, obviamente, del caso más llamaltivo, pucs, como veremos, tales textos establecen por lo común una tensión sintíxticosemántica verdaderamente límite, de emorme gasto comunication, peros de resultado estilistico sin duda sorprendente. Son en número muy sensiblemente menor que los sonetos en isodistribución. a los que px)demos considerar integrantes del grupo de textos mormules. Fil fundamento lịngüistico último de la antidistribución es el mantenimiento relalivamente inalterado de la proposición textual brisica hasta el limite de la manifestación lineal terminal. De tal manera, la sentencia, o la secucncia unisentencial compleja. que constituye el enunciado terminal léxicosintácticos de tal predicación básica, comparece inalterada en la manilestación inicial. El reticulado textual de kss catorce versos lo completan transformaciones relativamente simples de expansión de algunos clementos de la proposición textual, tales como repeticiones, apossiciones, transformaciones de expansión muy elementales, etc.

Como ejemplo general, muy evidente, de la descripción precedente de la antidistribución podriamos recordar el (ass) del tan famoso soneto 126 de la definición del amor a través de la enumeración antitética. "Desmayarse, atreverse, estar furioson " $"$, en el cual los trece primeros

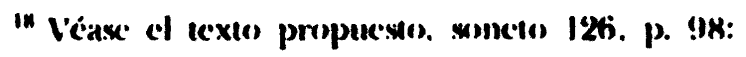

\footnotetext{
Desmayarse. atrecrerse, cestar furinown. aspero, tixerms, liberal, ('mpluivos. akentados, mortal. difunto, vives, leal, traiklor. cobarde y animoser:
} 
versos contienen sólo el contenido semántico del elemento de la proposición nuclear el amor es esto (estado de confusión = antítesis), en este caso bo predicado. Claro está que no se trata siempre en todos estos textos de una simple predicación nominal. Con más frecuencia, sonetos también puramente antidistributivos están constituidos como expansión de otro componente cualquiera de una predicación no nominal; tal sería el caso del soneto 6, en la frase-proposición básica textual: El ejemplo de mi fe vence en fama a cuantos ejemplos escritos tiene hoy el mundo ${ }^{19}$.

2.1.2. Por lo general, los ejemplos más claros y puros de antidistribución son aquellos, como acabamos de decir, en los que el rasgo antidistributivo asociado al de unisentencialidad estricta lo provee la modalidad sintáctico-pragmática sintomática. La antidistribución sirve estilísticamente al énfasis del síntoma vehemente, en especial en casos de definición quejosa ponderada o de proclamación. Ya hemos anunciado antes el soneto 126 como una de las muestras más puras de antidistribución, en cuanto que el texto completo constituye el cuerpo de la predicación nominal. Otros ejemplos semejantes son los sonetos 56, "Que eternamente las cuarenta y nueve», o el 61, «Ir y quedarse, y con quedar partirse». En ambos sonetos la simplicidad sintáctica del texto refuerza claramente la estructura antidistributiva unisentencial. Se trata de dos

no hallar fuera del bien centro y reposs), mostrarse alegre, triste, humilde, altivo, enojado, valiente, fugitivo, satisfecho, ofendido, recekso);

huir el rostro al claro desengaño, beber veneno por licor süave. olvidar el provecho, amar el daño;

creer que un cielo en un infierno cabe. dar la vida y el alma a un desengaño: esto es amor: quien lo probó lo sabe.

19 Véase el texto completo, soneto 6, p. 26 :

Al sepulcro de Amor, que contra el filo del tiempo hizo Artemisa vivir claro, a la torre bellísima de Faro. un tiempo de las naves luz y asilo;

al templo efesio, de famoso estiko, al coloso del sol, único y raro, al muro de Semíramis reparo, y a las altas pirámides del Nilo;

en fin, a los milagros inauditos, a Júpiter olímpico y al tempko. pirámides, coloso y mausoleo.

y a cuantos hoy el mundo tiene escritos, en fama vence de mi fe el ejemplo: que es mayor maravilla mi amor solo. 
casos de construcciones enumerativas repetitivas, montados en series paralelas de un solo elemento, y reforzadas por la persistencia del recurso conectivo, anáfora en el 56, antítesis en el 59. Otros casos de expansión del sujeto a través de una transformación de frase de relativo o de acumulación de vocativos los ofrecen los sonetos 132, cuya estructura seria: «Al viento se encomienda, al mar se entrega (v. 1), etc., quien pone su esperanza en mujer flaca* (v. 14), y 155 -con estructura: « Belleza singular, ingenio raro (v. 1)... Lucinda hermosa (v. 11)... dame a escribir como a penar sujeto (v. 14)-, caso este último el único que hemos encontrado en Lope de antidistribución pura en soneto no sintomático. Expansión de elementos simples de textos unisentenciales son los sonetos 6, antes aludido, con texto repetitivo anaforico; el soneto 52, con anáfora inicial en cada estrofa -estructura: «Entre aquestas columnas abrasadas (v. 1)... busco memorias de mi bien perdidas (v. 12), , y el soneto 127, reiteración de una modalidad circunstancial, con fuerte anáfora casi en todos los versos -estructura: «Con una risa entre los ojos bellos (v. 1)... habla Lucinda TTriste del que escucha! (v. 13).

Casos de mayor complicación sintáctica dentro de la fórmula general de antidistribución los constituyen aquellos textos en los que el cuerpo básico del soneto se configura como unidad sentencial en sí misma, estableciendo la contrapartida de la oración que marca la antidistribución, con la que forma conjuntamente una frase compleja de dos elementos. Por ejemplo, la frase comparativa constituida por el soneto 170: "No tiene tanta miel Atica hermosa (v. 1) ... que doy suspiros por Lucinda en vanò ( $v$. 14), con reiteración de la fórmula no tener a lo largo de los trece primeros versos. $O$ bien textos descriptivos en los que él objeto de la descripción, paisaje, tormenta, etc., pese a su extensión en la manifestación lineal terminal del texto, no constituye la entidad temática, sino que establece el marco circunstancial donde se sitúa el tema básico de la manifestación, como el soneto $13^{20}$. Análogamente, el

${ }^{20}$ A casos como el presente nos hemos referido en L. T. T. L. a propósito de unos sonetos de Góngora calificados por el crítico E. Orozco Diaz como "manieristas», precisamente en función del desplazamiento sintáctico y temático, descrito aquí por nosotros como antidistribución. Ver el soneto en concreto, soneto 13, p. 30:

Con imperfectos cínculos enlazan rayos el aire, que, en discurso breve. sepulta Guadarrama en densa nieve, cuyo blanco parece que amenazan.

Los vientos campo y nubes desplazan; el arco el mar con los extremos bebe; súbele al polo, y otra vez le llueve; con que la tierra, el mar y el cielo abrazan. 
soneto 149, con estructura enumerativa descriptiva del campo de batalla de Argel, contrapuesta explícitamente a la correlación modal que queda manifestada sólo en el último terceto: «Y así mis versos... serán guerra mortal de mis sentidos» 21.

En algunos de los textos últimamente referidos comienzan a descubrirse ya síntomas de una mayor complejidad sentencial, que los que hemos dado como ejemplos arquetípicos. La causa es que la unisentencia simple o compleja entra en combinación generalmente paratáctica con alguna otra sentencia simple dentro del terceto final-conclusivo. Véanse casos de tal índole en el soneto 69: "Si todas las espadas que diez años» -anáfora de si-... «no es posible que el alma lo sintiese"... (v. 12), inmediatamente seguido de la disyunción paralela «o que si lo sintiese y os mirase, / entre las penas, gloria no tuviese» (v. 13-14). O bien el soneto de confidente 160 , donde además se ha de marcar, asimismo, un grado sensiblemente mayor de complejidad sentencial en la constitución interna del sujeto de la unisentencia -estructura: «Esto de imaginar si esta es su casa, etc., obliga, Marcio, a enamorar de nuevo»-; en

\footnotetext{
Mexió en un punto la disforme cara la variedad con que se adorna el suclo. perdiendo Febo) de su curso el modo.

$Y$ cuando ya parece que se para el armonía del eterno cielo. salió Lucinda y serenóse todo.
}

El editor Blecua, que sigue a J. G. Fucilla en este (aso, señala el antecedente italiano de este soneto en el texto de Ariosto "(hiuss era il sol da un tenebross) velon. Ejemplos (onon) éste apuntan a la necesidad, que sentimos vivamente, de extender al análisis de sonetos en la tradición italiana los rasgos que se descubren en la española. una ve\% que se hava cumplido la imprescindible sistematización y catalogación tipológica. Sólo asi podrán establecerse con carácter riguroso los casos de constantes textuales y los rasgos de hallay.go' individual poético.

${ }^{21}$ En este grado incluimos nosotros, entre los más puramente antidistributivos, el (urioso soneto de acumulaxión antitética 134. p. 103:

Halló Bacos la parra provechosa. (ieres el trigo, Glauco el hierro duro, los de Lidia el dinero mal seguro.

Casio la estatua en ocasión famosa;

A pis la medicina provechosa.

Marte las armas y Nembrot el muro,

Scitia el cristal, Galicia el ámbar puro,

y Polinoto la pintura hermosa.

Triunfos Libero, anillos Prometeo, Alejandro papel, llaves Teodoro, Radamanto la ley, Roma el gobierno;

Palas vestidos, carros Ericteo, la plata halló Mercurio, Cadmo el oro. Amor el fuegro, y celos el Infierno. 
éste la oposición es adversativa: * pero saber cómo paso la ofensa, / no sólo desobliga, mas enfría». Entre tales casos de complejidad sentencial creciente no dudaríamos en incluir como plenamente antidistributivos ciertos textos con modalidad expresiva apelativa, a la dama - soneto 1.4 - y al confidente - sonetos 9 y 12-, que constituirian en sí mismos estructuras raras de antidistribución apelativa, ya que, como hemos dicho, la asociación sintáctico-semántica de la antidistribución unisentencial la constituye la expresión sintomática en función temática de definición quejosa y proclamación enfática.

2.1.3. En esta línea de complejidad sentencial de los elementos que constituyen la antidistribución, se nos of recen otros nueve textos, en los que, pese a la evidente diferencia apuntada, en especial con los sonetos tipo, la estructura básica de la antidistribución - ponderación extensa, resolución abrupta final-, nos parece que se cumple perfectamente en todos. De ahí que los incluyamos como casos de antidistribución plurisentencial. En el orden de su complejidad sentencial creciente, mencionaríamos como los casos de mayor proximidad a la antidistribución, ambos con ponderación compleja pero con resolución unisentencial, los sonetos 99, «Perderá de los cielos la belleza», y 102, «Cuando el mejor planeta en el diluvio». La ponderación y resolución sentencial complejas caracterizan los siguientes sonetos: 27 , «Bien fue de acero y bronce aquel primero»; 76, «Sufre la tempestad el que navega»; 96, «Mis recatos, mis ojos, mis pasiones»; 110, «Un instrumento mismo sonoroso*, y 117 , "Rompa con đukces números eI canto». Dos sonetos más de cọmplejidad límite, que no dudamos, sin embargo, en calificar de antidistributivos, son el soneto 3 «Cleopatra a Antonio en oloroso vino», donde la narración de la anécdota histórica del regalo y sacrificio de la perla en el vino, en las tres primeras estrofas, sirve de base ponderativa al evidente término de antidistribución en el último terceto: "Quedó la perla sola en testimonio / de que no tuvo igual, hasta quel día, / bella Lucinda, que naciste al mundo». Y, en segundo lugar, el caso de más enrevesada sintaxis que hemos censado en este grupo, tanto en la ponderación como en la resolución, es el del soneto 32 , «Si gasta el mar la endurecida rocaw.

\subsection{Isodistribución}

2.2.1. La mayor parte de los sonetos amorosos de Lope de Vega, ya desde las Rimas de 1609 , coinciden en respetar la estructura métricosintáctica que hemos definido como isodistribución. Dejando aparte los veintiocho textos narrativos, que consideramos bajo otra perspectiva, la proporción entre los textos expositivos es abrumadoramente favorable a 
la isodistribución; sólo veintiséis sonetos antidistributivos uni y plurisentenciales, sobre un total de casi noventa composiciones de isodistribución. Este conjunto de sonetos, unas tres veces más numeroso que la antidistribución, ofrece, a su vez, suficientes peculiaridades internas para progresar objetivamente en la subclasificación de la isodistribución, con criterios inmediatos, claros y explícitamente textuales. Conviene no olvidar, sin embargo, que la construcción de una tipología como la nuestra debe evitar siempre los riesgos de exceso en la subjetividad analítica. Tales riesgos crecen, sin duda, en nuestra experiencia, cuando se pretende llevar demasiado lejos la cuadrícula taxonómica. El límite de tal progresión debe crearlo siempre la estimación del punto de consciencia evidente del emisor del texto, en este caso el poeta amoroso, quien sin duda reconocía consciente o inconscientemente unas pautas sintácticas de tradición -como unas pautas temático-semánticas- en las cuales planeaba inscribir o sentía incluido el texto durante el proceso creativo.

Tales líneas de subclasificación las crea, en primer lugar, la condición dual o múltiple de la macroestructura textual sintáctica del soneto. La mayor parte de las veces existe a ambos lados del límite estrófico entre cuartetos y tercetos, una solidaridad o consecuencia recíproca entre cada par estrófico, quizá más explícitamente paralela entre los cuartetos. En tales casos se nos ofrece la estructura de isodistribución dual. Por el contrario, si cada uno de los tres límites estróficos internos del soneto marca a su vez un límite sintáctico-semántico absoluto, tanto a la observación explícita como, incluso, a la implícita, nos encontraríamos con un tipo especial de textos - no muy numerosos, por cierto, en estas Rimas humanas del primer Lope, pero que se irá adensando enormemente en él y que será la estructura básica en poetas como Quevedo o Herreradonde la isodistribución llega a su límite, y al que denominaremos soneto con estructura de isodistribución múltiple.

2.2.2. Isodistribución dual. Se trata, como hemos dicho, de la clase más común entre todos los sonètos amorosos de Lope de Vega. Dos grandes modalidades textuales se ofrecen a una consideración inmediata tras el examen de este tipo de textos. La isodistribución dual supone, como ya se ha indicado, un cierto grado de cohesión entre los miembros de cada uno de los pares estróficos, cuartetos y tercetos, así como un cierto modo de delimitación de dichos pares entre sí. Uno y otro efectos pueden verse corroborados por marcas explicitas, o bien realizarse sin marcas explícitas, sino a través de fenómenos internos de coherencia de naturaleza semántica o pragmática.

2.2.2.1. Examinemos en primer lugar el conjunto de sonetos con isodistribución sin marcas explicitas. En el caso de Lope de Vega se trata de 
una clase de textos muy abundantemente representados, en los cuales no existen marcas externas explicitas de conectores ni de separadores sintácticos, como conjunciones de correlación, formas verbales con re. lieve enfático como el imperativo, fórmulas exclamativas o de interrogación enfática, vocativos, etc. Las cuatro estrofas del soneto se suceden por lo común sin ninguna de dichas señales, quedando, sin embargo, perfectamente marcada la arquitectura isodistributiva dual del discurso textual a través de procedimientos sintáctico-semánticos internos. El conjunto de tales procedimientos ofrece fórmulas bastante complejas y variadas en detalle; sin embargo, nosotros creemos que pueden ser perfectamente sumarizadas en dos grandes grupos: paralelismo constructivo y agrupaciones internas textuales.

2.2.2.2. Considero casos de paralelismo constructivo aquellos en los que el procedimiento de geminaciones y reiteraciones de una cierta construcción determina explícitamente el tipo de solidaridades y fracturas en el cuerpo del soneto, que hemos definido como isodistributivas. Un ejemplo límite por su evidencia lo ofrecería el soneto 25 de las $R$ imas ${ }^{22}$, con el tema del carpe diem. Se trata de la clara fractura por geminación absolutamente paralela de cuartetos y tèrcetos, reforzada además la solidaridad recíproca de cada una de tales unidades a través de las marcas léxicas explícitas intratextuales sintáctico-semánticas que configuran el tema carpe diem. La estructura de este soneto podría representarse a bla $b$-mediante la siguiente distribución de marcas y contenidos léxico-semánticos:

a) 1. er cuarteto: antes que (degradación).

b) $2 .^{\circ}$ cuarteto: estima (imperativo epicúreo) / que con el tiempo... huya (amenaza de olvido).

\footnotetext{
p. 37:

Antes que el cierzo de la edad ligera seque la rosa que en tus labios crece, y el blanco de ese rostro, que parece cándidos grumos de lavada cera,

estima la esmaltada primavera, Laura gentil, que en tu beldad florece, que con el tiempo se ama y se aborrece, y huirá de ti quien a tu puerta espera.

No te detengas en pensar que vives, oh Laura, que en tocarte y componerte se entrará la vejez sin que la llames.

Estima un medio honesto, y no te esquives; que no ha de amarte quien viniere a verte, Laura, cuando a ti misma te desames.
}

${ }^{22}$ Ofrecemos para su más cómoda verificación por el lector el texto de este soneto 25, 
a) 1. ${ }^{\text {er }}$ terceto: no te detengas... que se enterará la vejez (degradación).

b) 2. terceto: estima (imperativo epicúreo) / que no ha de amarte (amenaza de olvido).

Sin llegar al punto extremo de este texto -en realidad dos composiciones soldadas sobre el carpe diem- son muy numerosos los casos con esta clase de estructura, Un tipo muy homogéneo lo constituyen sonetos en los que existen dos formulaciones paralelas en la estrofa primera dé cada par métrico, seguidas inmediatamente de una construcción adversativa en la estrofa siguiente. Como ejemplo, obsérvese el soneto 23 bajo la fórmula: $a$ (Prueba a engañar), $b$ (mas) / $a$ (Voile llevando de uno en mil engaños), $b$ (pero) ${ }^{23}$. Esta misma fórmula $a b$ (pero)/a $b$ (pero) se repite en los sonetos $44,93,123$ y $138^{24}$. Idéntica estructura, pero sin la constante adversativa, se descubre también en el soneto 50: «Marcio, yo amé y arrepentíme amante* con el confidente en vocativo encabezando cada una de las dos mitades y formulaciones con predominio nominal en las estrofas segundas, o también el 180, «Matilde, no te espantes que Felino».

El grupo de sonetos descritos es, sin duda, el que presenta más estricto y evidente paralelismo constructivo. Relativamente próximas estructuras a la anterior son las de tres sonetos que guardan proporción estructural del tipo a a / b b. Así, el soneto 34 esto-este / veo-veo, el 89 si-si / pintarle-pintarle y el 180 imperativo-imperativo / si-si. El paralelismo se va alternando en nuevas formas de repetición con tres elementos, como los de los sonetos 52; narración / fue-fue, y 162: narración / aguarda / no aguardes, respondiendo a una estructura $a b / c c$. Inversa pero idéntica es

\footnotetext{
${ }^{23}$ Página 36:
}

Prueba a engañar mi loco pensamiento con la esperanza de mi bien perdido, mostrándole, en mil nubes escondido. un átomo no más de algún contento.

Mas él, que sabe bien que cuanto intento es apariencia de placer fingido, se espanta de que, estando al alma asido, le engañe con fingir lo que no siento.

Voile llevando de uno en mil engaños, como si yo sin él tratase dellos, siendo el mayor testigo de mis daños.

Pero siendo forzoso padecellos, joh quien nunca pensase en desengaños, o se desengañase de tenellos!

${ }^{24}$ Se trata de los siguientes: 44, "Que otras veces amé negar no puedo"; 93, «Rompe las conchas Hércules famoson; 123, «Cayó la Troya de mi alma en tierraw; 138, "Inmenso) monte, cuya blanca nieven. 
la estructura del soneto 113 desde-desde ' exposición, y 97 si-si / exposición. con la estructura. por tarr(o), a aib c. igualmente tres elementos en otra disposición paralela. de espejo, entran en juego en el caso de los sonetos 108, "Amor por ese sol divino jura*. y el 183, «Fugitivo cristal el (urso enfrena* con estructura $a b / b c$.

2.2.2.3. H.l grupo de sonetos en isodistribución dual sin marcas explicitas con agrupaciomes internas textuales, representa un tipo textual bastante frecuentado por Lope de Vega en las Rimas de 1609. A diferencia de los textos antes analizados, el paralelismo y la congruencia que se descubren en estos textos y que refuerzan los efectos de isiodistribución, no vienen ofrecidos por paralelismos explícitos de refuerzo léxico en el (cuerpo) de cada una de las cláusulas, sino por representaciones semánticas correlativas. Así, la doble correlación luz-1)scuridad, repetida en cuartetos y tercetos, establece el doble orden de cohesión y de separaciones en el soneto 59. "Al sol que os mira. por miraros miron. En el 66 las directrices las constituren, en nuestra opinión, las imágenes semánticas de "fueg()" y "abrasarse" que presiden la estructura textual sintáctica del primer elemento, cuarteto y terceto, de cada pareja estrófica en el texto. En la misma disposición que los vocativos fuertemente enfatizados dirigidos a la dama en dos sonetos apelativos, el 88 y el 105, a nuestro juicio también elementos directrices de la organización isodistributiva. En grado aún más débil se nos presenta la marca correlativa de fuerte nominalización en el segundo cuarteto y primer terceto del soneto 60 , "Quien dice que en mujeres no hay firmeza».

La correlación del tipo que nos ocupa queda mejor representada en los sonetos donde las partes en isodistribución están marcadas por la acción de roles distintos o sistemas expresizos diferentes. Por ejemplo, en el sonito 29, el juego símil-aplicación personal crea a los dos lados de la cesura isodistributiva una imagen palpable de tal estructura; sólo; como venimos diciendo, a través de la apelación de representaciones semánticas $^{2 s}$. Idéntica estructura de símil y aplicación, en distribución variable aunque siempre dentro de la isodistribución, organiza la textura de los sonetos 115, "A Juan Bautista Labaña»; 158, "A una dama que se lim-

2s V'éase el texto aludido, soneto 29, p. 40:

Fue Troya desdichada. y fue famossa. ruelta en ceniza, en humo convertida. tanto. que Grecia, de quicen fue vencida. está de sus desdichas envidikma.

Así en la llama de mi amor cekssa. pretende nombre mi abrasada vida. y el alma en escos ojos encendida. la fama de atrevida mariposa. 
piaba los dientes», y 161, «Cual engañado niño que contento». El mismo tipo, con estructura correlativa. lo llenan diferentes clases de correspondencia, desde distribuciones temático-semánticas, como la del soneto 133 con el tema de "proclamación en los cuartetos y aglorificación en los tercetos, o el 182, que se distribuye temáticamente, desengañomuerte. En ocasiones, es el juego correlativo de constantes objetivas universales, como pasado-futuro, en el soneto 82 , o bien propiamente concernientes a la estructura expresiva temática, como el paso de presentación a "rol» de personaje en el soneto 129, o el juego de expresión impersonal/expresión de problemas del yo en el 133.

2.2.2.4. Isodistribución dual con marcas explicitas. Clase de textos muy frecuentada por Lope de V'ega, su presencia es relativamente mayoritaria en las Rimas de 1609, sobre las que elaboramos primeramente la clasificación tipológica, pero luego progresivamente abandonada en sus obras más tardías; siendo la incidencia proporcional de este tipo en otros escritores positivamente menor. A diferencia de los casos anteriores, los límites de la isodistribución aparecen aquí muy directa y explícitamente marcados. La fórmula más generalizada en Lope consiste en señalar explícitamente el tránsito entre las dos mitades textuales del soneto a través de expresiones verbales enfatizadas, como el imperativo, reforzado en ocasiones por exclamación.

2.2.2.5. Dada la gran densidad de sonetos apelativos existentes en Lope, podemos establecer para él un tipo textual muy preciso, repetido innumerables veces. Su estructura sería la siguiente:

Cuartetos: Apelación, vocativo/fórmula apelativa-discursiva.

Tercetos: $\begin{cases}1 .^{\circ} & \text { Exclamación/imperativo. } \\ 2 .^{\circ} & \begin{array}{l}\text { Explicación-síntesis (muy frecuentemente introducida } \\ \text { por pero o que). }\end{array}\end{cases}$

Combinando las alternativas manifestadas en el esquema anterior, resultarán los siguientes grupos:

1. Sonetos con apelación en vocativo en los cuartetos/imperativo en primer terceto. Esta clase, muy generalizada se da en las tres suertes de apelacio-

\footnotetext{
Cuando soberbia y victoriosa estuvo, no tuvo el nombre que le dio su llama: tal por incendios a la fama subo.

Consuelo entre los miseros se llama que quien por las venturas no la tuvo, por las desdichas venga a tener fama.
} 
nes que hemos establecido: a la dama ${ }^{26}$, al confidente ${ }^{27}$ y al poeta mismo, o a alguna de sus fórmulas eufemisticas, como Amor, etc. ${ }^{28}$.

26 Véase una muestra de este tipo, soneto 152, p. 113:

Hermosa Parca, blandamente fiera, dueña del hilo de mi corta vida, en cuya bella mano vive asida la rueca de oro y la mortal tijera;

hiladora famosa, a quien pudiera rendirse Palas y quedar vencida; de cuya tela, Amor, de oro tejida, si no fuera desnudo, se vistiera.

Dete su lana el vellocino de oro, Amor su flecha para el huso, y luego mi vida el hilo que tu mano tuerza.

Que a ser Hércules yo, tanto te adoro, que rindiera a tu rueca atado y ciego, la espada, las hazañas y la fuerza.

27 Véase, asimismo, una muestra de este tipo, soneto 37, p. 45:

Céfiro blando, que mis quejas tristes tantas veces llevaste; claras fuentes, que con mis tiernas lágrimas ardientes vuestro duke licor ponzoña hicistes;

selvas, que mis querellas esparcistes; ásperos montes, a mi mal presentes; rios, que de mis ojos siempre ausentes, veneno al mar, como a tirano, distes;

pues la aspereza de rigor tan fiero no me permite voz articulada, decid a mi desdén que por él muero.

Que si la viere el mundo transformada en el laurel que por dureza espero, della veréis mi frente coronada.

28 Véase una muestra del tipo aludido, soneto 145, p. 109:

Amor, no se engañaba el que decía que eres monstro engendrado de la tierra, que de los elementos eres guerra, luz de la noche, escuridad del día,

dios por temor, y rey por tirania, hijo de Marte, que la paz destierra, y de una errada, por quien siempre yerra. vencida la razón de tu porfia.

No te espantes de ver que te adoramos: que de gentiles a temor sujetos, la Muerte fue adorada por dios fuerte.

Así como a Muerte, altar te damos, pues todos dicen, viendo tus efetos, que eres hijo del Tiempo y de la Muerte.

Además de los tres ejemplos propuestos, otros sonetos de esta clase para los tres tipos de apelación son: A la dama, 58, „Dulce desdén, si el dano que me haces»; 125, «Mano 
2. Sonetos con fórmula apelativa discursiva en cuartetos/imperativo en el primer terceto. Dicha estructura apelativo-discursiva puede ser bien un razonamiento apelativo ${ }^{29}$, o bien la presentación de una viluación o estado ${ }^{30}$.

3. Sonetos con apelación en vocatizo en los cuartetos/y arlamación enfiatica en los tercetos ${ }^{31}$.

amorosa, a quien amor solía»; 140, "Estas postreras lágrimas te ofreæou”; 171. "Llamas y huyes; quieres y aborreces", y 189, "Querido manso mio, que veniste". Al confidente, 36. «Suena el azote, corredor Apolo». A si mismo, 136, "Probemos esta vez el sutrimiento»; 190 , "Papeles rotos de las propias manos".

29 Véase como ejemplo el soneto 70 , p. 64:

Quiero escribir, y el llanto no me deja; pruebo a llorar, y no descanso tanto; vuelvo a tomar la pluma, y vuelve el llanto: todo me impide el bien, todo me aqueja.

Si el llanto dura, el alma se me queja; si el escribir, mis ojos; y si en tanto por muerte, o por consuelo, me levanto, de entrambos la esperanza se me aleja.

Ve blanco, al fin, papel, y a quien penetra el centro deste pecho que me enciende le di (si en tanto bien pudieres verte)

que haga de mis lágrimas la letra. pues ya que no lo siente, bien entiende: que cuanto escribo y lloro todo es muerte.

Otro del mismo tipo sería el soneto 156, "Si para comparar vuestra hermosura», página 115.

30 Véase como ejemplo el soneto 83, p. 71 :

Yo no espero la flota, ni importuno al cielo, al mar, al viento por su ayuda. ni que segura pase la Bermuda sobre el azul tridente de Neptuno;

ni tengo hierba en campo, o rompo alguno con el arado en que el villano suda. ni del vasallo que con renta acuda provecho espero en mi favor ninguno.

Mira estas yedras, que con tiernos lazos, para formar sin alma su himeneo, dan a estos verdes álamos abrazos.

$Y$ si tienes, Lucinda, mi deseo, hálleme la vejez entre tus brazos y pasaremos juntos el Leteo.

Otros de esta clase serían el 28, "A un caballero llevando a su dama a enterrar él mismo», p. 39, y el 173, «Del corazón los ojos ofendidos», p. 126.

31 Véanse como ejem plo el soneto 81, p. 70 :

Lucinda, yo me siento arder, y sigo el sol que deste incendio causa el daño; que porque no me encuentre el desengaño, tengo al engaño por eterno amigo. 


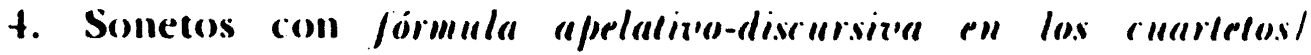
exclamación enffítica en el primer terceto ${ }^{32}$. Pequeño numero de texilos en los que se registran, mo ebstante. las dos peculiaridades marcadass en b) ${ }^{33}$.

En sonetos sintométicos, el tips) correspondiente lo ofirece unal classe bien representada de textos donde, naturalmente, la fómmulat constante de los cuartetos no es el voxativo, sino un discurss) simtomáticosexpositivo. Pero el rasgo determinante exclamattion y la fórmula explicationeconclusiva en cada uno de hos tercetos, comparece de forma idéntica ${ }^{34}$.

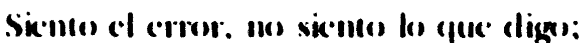

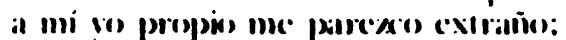

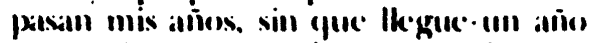
yue este seguro yo de mi commigno.
\end{abstract}

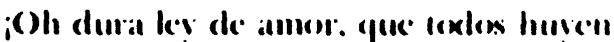
lat callsiat de sll mal. Y vol la espexur) siempre en mi mangen. comon humikle rios!

Peros si las cestrollas dano imfluseno. y conl las de lus ojos naki y mucoro.

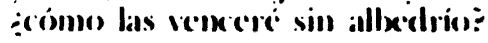

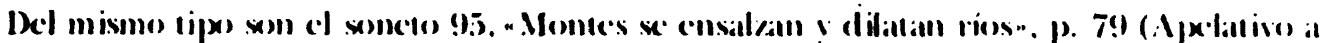

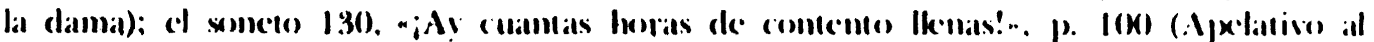

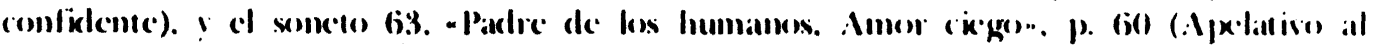
Amor).

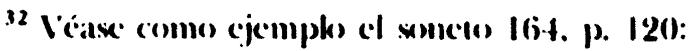

Si el pardre universal de cuamto veos ('ll la nallurakeoa nuesira humalla. desprecioi la selllencial sobxralla.

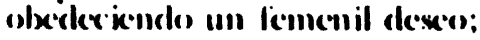

si un rev Davikl y un navatreno hebreos.

a Borsiale y a Dálicla tiralla.

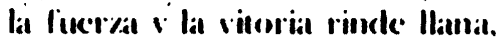

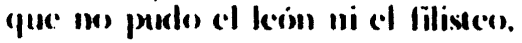

acn que valor mis ojes se lianom. y presumió mi ingenio saber tant(o). que IIO ke likicera ll hermestura agratik):

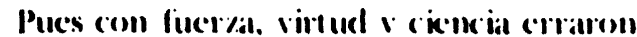
Adain el primer lomblore. Diavel salllo. Sansin el fucrte y Salkmin el Salbus.

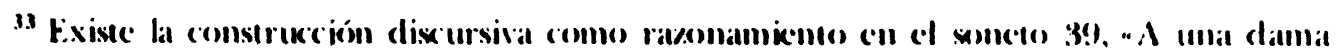

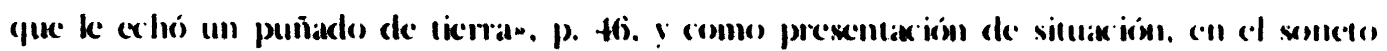
101. "(iatio la torre que en el viento havian-. p. K2.

34 l'éase comm cjemplos el sumcto 2. p. 2.3:

(iuanclos imagino de mis breves dias kos mucluss que el tiranos Amor me debe y en ini cabclks antixipar la nieve imás que loss años lass tristeyas mias. 
2.2.2.6. Muy semejante a los casos presentados en el parágrafo anterior es el de un determinado número de textos - no desdeñableya en las Rimas, en los que la fórmula de contraste entre cuartetos y tercetos la establece, no una oposición verbal enfática o cualquier otra marca abrupta de énfasis, como exclamación o interrogación enfática: sino el simple cambio de la fórmula apelativa inicial de los cuartetos -casi siempre, como sabemos, potenciada por estructuras de apelación inmediata en vocativo- a un tono expositivo dialogístico, con su construcción claramente subrayada por fórmulas explícitas de conexión, y marcado por una sintaxis rica en partículas continuativas ${ }^{35}$. Aunque sobre la muestra de las Rimas humanas el número de estos textos discursivo-conectivos no sea abrumadoramente representativo; sin embargo la importancia numérica del tipo estructural en el caso de la

\footnotetext{
veo que son sus falsas alegrias veneno que en cristal la razón bebe, por quien el apetito se le atreve vestido de mis dukes fantasías.

¿Qué hierbas del olvido ha dado el gusto a la razón, que, sin hacer su oficio, quiere contra razón satisfacelle?

Mas consolarse puede mi disgusto, que es el deseo del remedio indicio, y el remedio de amor querer vencelle.
}

Otros del mismo tipo son: el soneto 7, «Estos los sauces son y ésta la fuente», p. 26; el 11, "Cuando pensé que mi tormento esquivo»; el 33, "A un loco favorecido de una dama», y el 40, "Mis pasos engañados hasta ahora*.

${ }^{35}$ Véase el siguiente ejemplo, soneto 43, p. 48:

Ojos, por quien llamé dichoso al día en que naci, para morir por veros, que por salir de noche a ser luceros cercáis de azul la luz que al sol la envia;

hermosos ojos, que del alma mía un inmortal engaste pienso haceros de envidia del safir, que, por quereros, entre cristal y rosa el cielo cría;

agora si que vuestras luces bellas son de mi noche celestial consuelo, pues en azul engaste vengo a vellas.

Agora sí que sois la luz del suelo, agora sí que sois, ojos, estrellas, que estáis en campo azul, color de cielo.

Otros textos de esta clase son: Apelativos a la dama, soneto 153, «Si la más dura encina que ha nacido"; 184, «Lagrimas, que partiendo de mi cielo»; al confidente, el soneto 8, «De hoy más las crespas sienes de olorosan; el 119, "IAy duke puerta en cuyo mármol cargas"; el 192, "Artifice rarisimo, que a Apeles", y el 141, al amor: "Amor, no pienses que te pintan tierno. 
producción de otros poetas en nuestro Siglo de Oro es muy notable. Y en la propia evolución de Lope, esta clase estructural irá afirmándose, frente a la otra modalidad dual con marcas, la enfática, hasta llegar a dominar claramente sobre ella en la estructura general de las $R$ imas de Burguillos de 1634.

Un grupo de textos, en cierto modo mixto, pues participa de la forma delimitativa discursiva de los sonetos anteriores, pero con fórmulas de apelación enfática, imperativas o exclamativas en el segundo terceto, b constituye un considerable grupo de sonetos en apelación a la dama y al confidente ${ }^{36}$. Como en tantos otros casos, hemos de llamar la atención en este punto sobre el hecho de que, por razones del método expositivo adoptado en este trabajo que nos ha hecho aconsejable trazar nuestro esquema básico de partida sobre el contenido textual de las Rimas de 1609, la clase que aparece aquí como de estructura mixta, - y que, como hemos dicho, es por definición difícilmente deslindable de sus componentes inmediatos - desaparecerá casi de modo total en la práctica artística posterior de Lope de Vega; siendo casi inexistente, igualmente, en el inventario de sonetos amorosos de Garcilaso, Herrera, Quevedo y Góngora, examinado en este trabajo.

Para concluir con nuestras observaciones sobre este grupo de textos de los apartados 2.2.5. y 2.2.6. conviene que, una vez más, tengamos en cuenta la advertencia inicial de que lo que verdaderamente debe predominar en todas las anteriores subclasificaciones, cuyas posibilidades no hemos querido agotar, deben ser más bien los aspectos comunes. Es decir, la condición común de marcas explícitas singularmente de combinación del vocativo inicial, con la exclamación, el imperativo, o la expo-

\footnotetext{
${ }^{36}$ Vease como cjemplo el soncto con el que se abre precisamente el libro de las Rimas,
} wincto 1. p. 23:

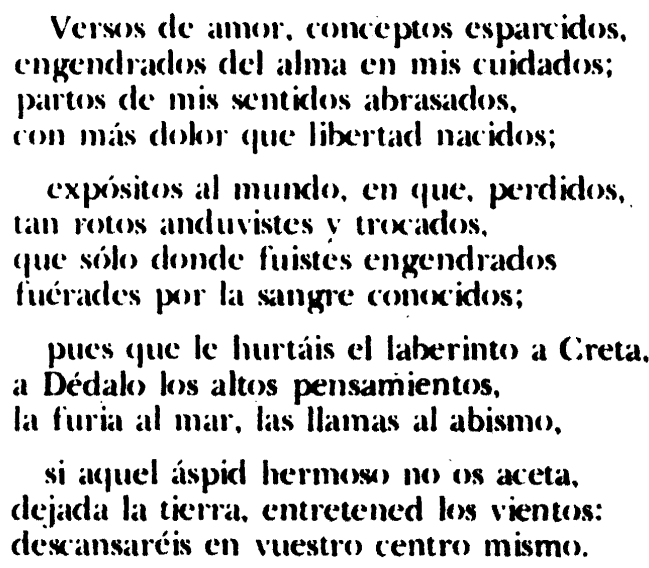

Otros textos análogos los of recen los sonetos 10, 41, 45, 65, 72, 135, 143. 
sición lógico-discursiva en los tercetos, a través de los cuales todos estos sonetos se oponen y diferencian de los otros sonetos de isodistribución sin marcas, como los dos tipos de organización textual mejor marcada que cultivó Lope de Vega.

Téngase en cuenta las observaciones adelantadas por nosotros en el apartado inicial (0) de este trabajo. Obviamente, el caso de esta reclasificación interna de la macroestructura argumentativa dual enfática constituye quizá el mejor ejemplo que se pueda dar -ntre los existentes en este trabajo- de una subclasificación de la construcción textual macroestructural casi al límite de la microsintaxis. La división en cuatro subclases será también, por lo mismo, la más lábil de todas las categorías tipológicas del esquema, precisamente en función de que alcanza niveles de la macroestructura próximos a la zona de las decisiones individuales estilísticos microtextuales. Es ese dominio, como hemos dicho y tendremos ocasión de repetir frecuentemente, el que ofrece más posibilidades no sólo ya a la oscilación personal de las decisiones estilísticas de cada poeta, sino aun del mismo poeta en momentos distintos de su evolución estilística, a través de su propia obra. Establecido nuestro punto de vista inicial para la organización tipológica que nos ocupa, en torno a las Rimas de 1609, queda de evidencia que esta primera etapa - no se olvide, por lo demás, que básicamente todos los sonetos de esta colección son anteriores a La hermosura de Angelica, de 1602- viene marcada en la producción de Lope por un ideal de estilo forzadamente enfático, que se define, por lo que a las macroestructuras de argumentación se refiere, en el adensamiento de las marcas enfáticas en la construcción del texto y en la naturaleza apelativa de una gran mayoría de sonetos. Pero tal frecuencia -que determina y justifica la necesidad de nuestra reclasificación del tipo dual enfático hasta el establecimiento de cuatro órdenes- se debilitará muy poderosamente en el transcurso de la evolución estilística de Lope de Vega, llegando incluso a invertirse con respecto a estructuras aquí poco frecuentadas, como las de isodistribución múltiple, en la revisión general antitópica última del «corpus» tópico amorosocortés, que Lope quiso llevar a término en sus Rimas de Tomé de Burguillos, publicadas en 1634, es decir, prácticamente con el presentimiento del final de su vida.

2.2.3. Isodistribución múltiple. Se trata en este grupo de un conjunto de textos relativamente corto aún en las Rimas de 1609 -catorce en total-, en los que se produce una más completa conjunción entre las pausas estróficas y los límites mayores de la sintaxis sentencial. El grupo relativamente más numeroso de esta clase de sonetos es aquel en que se forma una especie de clímax expositivo de cláusulas relativamente autó- 
nomas, al menos sin marcadas relaciones a través de conectores, para desemboxar en el último terceto en una expresión enfático-exclamativa. Tales textos no vienen a diferenciarse grandemente del grupo) de los de isodistribución dual que en 2.2.6 hemos denominado mixto. La diferencia estriba en la más reforzada interdependencia del mixto entre los cuartetos, y por lo general la presencia de partículas continuativas subrayando el límite entre cuartetos y tercetos ${ }^{37}$. En algunas ocasiones las cuatro estrofas del múltiple. en sonetos apelations, vienen a constituir una sucesión de apelaciones enfáticas. generalmente manifestadas como rocativos ${ }^{3 *}$. Por último, citaremos un grupo de tres textos que manifiestan esta tendencia a la desconexión y autonomía métrico-sintáctica !

37 Véase de este tipo un claro ejempks en el soneto 75. p. 67:

No me quejara yo de larga ausencia. si. como toxdos dixen. fuera muerte: mas pues la siento. yes doks) tan fuerte. quejarme puerdos sin pedir likencial.

F.n nada del morir tience apariencia. que si el suceno es su image'n y divierte la vida del dokor. tal es mi suerte. que aun durmiendo no le visto su preserecia.

Con más razón la llamarán loxura. efeto de la causa y accidente. si el no dormir es el mayor testigo.

¡Oh ausencia peligrusa y mal segura. valiente con rendidos. que un ausente en sí vuelve la espada a su enemign!

Otros del mismo tipo son el 62, 71, 78. 92, 108.106.

3n Véase un ejempho en el soneto 79. p. 69:

Sosiega un poxo. airado temerosos. humilde vencedor, niño) gigante. cobarde matador. firme inconsciente. traidor leal, rendido vitoriosos.

Déjame en paz, pacifico furioss). villano hidal(go, tímido arroggante. cuerdo kxo,. filósofo ignorante. (iego lince, segurs) (auteloss).

Ama si eres Amor, que si proxuras descubrir, con suspechas y recelos, en mi adorado sol nieblas escuras.

en vano me lastimas con desvelos. Trate nuestra amistad verdades puras: no te encubras, Amor. si quieres celos.

(jtros sonetos de este tipos son el 42, 151 y 154. 
semántica de las estrofas, sin ninguna clase de refuerzos internos expresivos $^{30}$.

El caso de la isodistribución múltiple nos presenta la perspectiva, en cierto modo opuesta a la que nos of recía la clase enfática, y que comentábamos explícitamente al final del apartado anterior. La isodistribución múltiple tuvo, en el conjunto general de nuestra lírica del Siglo de Oro, una responsabilidad y un grado de frecuencia mucho más elevado del que nos hace suponer en principio la escasa muestra representada en las Rimas de 1609, de las que partimos - por razones de economía y conveniencia expositiva- para el establecimiento inicial de nuestra tipología básica. Téngase, sin embargo, muy presente esta advertencia desde ahora, pues la clase argumentativa de isodistribución muiltiple será una de las palancas fundamentales de la creación lírica de nuestro Siglo de Oro. Este mismo trabajo lo irá testimoniando progresivamente, a través de la constatación de su incremento en las sucesivas obras de Lope de Vega, y sobre todo en el contraste con la producción textual de la lírica amorosa de dos escritores tan importantes y representativos como Fernando de Herrera y Quevedo.

\subsection{Narración}

2.3.1. Como ya dijimos en (0) los textos narrativos constituyen una excepción singular de Lope de Vega, en quien resplandece siempre su condición primaria de dramaturgo. Centrándonos aquí estrictamente en la cuestión de la macrodistribución de la estructura textual de los sonetos, habremos de hacer en primer término una importante escisión objetivamente justificable en el conjunto de los textos narrativos. Consistirá en la distinción entre sonetos narrativos simples y sonetos narrativos.

${ }^{39}$ Un ejemplo lo constituye el soneto 168, p. 123:

Si verse aborrecido el que era amado es de amor la postrera desventura, ¿qué espera en vos, sehora; qué procura el que cayó de tan dichoso estado?

En vano enciendo vuestro pecho helado, pues lo que agora con violencia dura ya no es amor, es natural blandura con tibio gusto de un amor forzado.

Cuando vos me seguistes iba huyendo; huis agora vos cuando yo os sigo; si es amor, yo le tengo y no le entiendo.

Ya huyo, como esclavo, del castigo; guardaos, que ya me voy, $y$ al fin partiendo, no sé qué haré de vos, pues vais conmigo.

Otros son los sonetos 146 y 191 . 
dramatizados. Esta diferencia, que en principio parece sumamente dificil de establecer con rendimiento intersubjetivo, queda de manifiesto, sin embargo, con suma facilidad por la presencia de la marca de diálogo dramático, es decir, representación por parte del narrador de la voz 0 voces de los personajes expresada en forma y estilo directos. Por tanto, si se prefiere aludir a un rasgo más objetivo y fácilmente constatable en el cuerpo del texto, podemos complementar la anterior distinción hablando de textos narrativos simples (sin diálogo)/textos narrativos dramatizados (con diálogo-estilo directo).

Peculiaridad fácilmente imaginable en estos textos es que no existe antidistribución. Tal como se la ha descrito (2.1), la antidistribución constituye una modalidad de énfasis expresivo que no consiente la narración. $Y$, por otra parte, la condición de unisentencialidad en la propia proyección de la representación sintáctico-semántica de la macroestructura no es imaginable en el caso de la narración, y menos aún en el de la narración dramatizada, donde entran en juego, por definición, distintos roles personales: del narrador, de los diferentes personajes, etc.

Los textos narrativos son, por consiguiente, isodistributivos. En tal sentido no nos resulta difícil fragmentar el conjunto de textos narrativos según la categoría básica de la isodistribución, es decir dual y múltíple, según las características textuales correspondientes, descritas en los respectivos apartados. Por tanto, los textos narrativos (isodistributivos) pueden ser clasificados en los siguientes cuatro grupos.

1. Narrativos simples (sin diálogo)/duales ${ }^{40}$.

2. Narrativos simples/múltiples ${ }^{41}$.

3. Narrativos dramatizados (con diálogo-estilo directo)/duales ${ }^{42}$.

${ }^{40}$ Corresponderian a este grupo los sonetos siguientes: Sintomáticos: el soneto 4, «Era la alegre vispera del día», y el 5, «Sirvió Jacob los siete largos años». Representación: el soneto) 31, «Albania yace aquí, Fabio suspira*; el 80, «Por ver si queda en su función deshecho», y el 109, "Con lágrimas escucha Masinisa».

"Corresponderían a este grupo los sonetos siguientes: Sintomáticos: el 21, «A Baco pide Midas que se vuelva»; el 26, "En el sereno campo de los cielos, y el 124, «Blancos y verdes álamos, un día». Representación: el 18, «Piramo triste que de Tisbe»; el 35, «Ardese Troya y sube el humo oscuro», y el 90, "Salió Faetón y amaneció el Oriente».

${ }^{42}$ Corresponden a este grupo los sonetos siguientes: Sintomdicos: el 19, «Pasando un valle oscuro al fín del día; el 68, «Con nuevós lazos, como el mismo Apolo»; el 98, Conteniendo el Amor y el tiempo un día»; el 148, «Suspenso aquel divino movimiento», y el 175, «Deseando estar dentro de vos propia.. Representación: el 57, „Silvio en el monte vio con lazo estrecho»; el 87, «Pasando el mar el engañoso toro; el 174, «Daba sustento a un pajarillo un día»; el 181, "Con pálido dolor, ardiendo en ira»; el 186, "La blanca en el valor, venida a Esparian, y et '187, «Al rey Nino, Semíramis famosa". 


\section{Narrativos dramatizados/múltiples ${ }^{43}$.}

2.3.2. Trataremos de aclarar las peculiaridades de cada una de las clases anteriores, insistiendo en la curiosa impronta de su condición más o menos evidentemente dramática. Obviamente, son los narrativos aquellos textos donde tal dramaticidad se of rece més atenuada. No obstante, el indudable efecto dramático constituye el «continuum» que recorre el texto, dótándole de una coherencia superiór, incluso, a la misma coherencia lógica. Por eso es muy difícil de una parte establecer límites para la isodistribución dual, como no sea ácógiéndose a un cambio brusco de modalidad expresiva, como el paso de exposición simple a exclamación y exposición enfática que se descubre en el soneto $5^{44}$. Y, de otra parte, tampoco resulta fácil aceptar un tipo de isodistribución múltiple en estos sonetos, pues la continuidad de la situación dramático-pragmática se impōne sobre la evidente condición sintáctica de isodistribución múltiple de muchos de estos textos, totalmente ausentes de conectores interestróficos ${ }^{45}$.

\footnotetext{
${ }^{43}$ Corresponden a este grupo los sonetos siguientes: Sintomáticos: el 64, «Yo vi sobre dos piedras plateadas", y el 166, "Circe que de hombre en piedra me transforma*. Representación: el 16, «Sentado Endimión al pie de Atlante»; el 30, «¿Adónde vas con alas tan ligeras?»; el 91, «Al cuerpo de Faetón Límene mira», y el 172, «El ánimo solícito y turbado. Téngase en cuenta en general, a propósito de los sonetos narrativo-dramáticos rocogidos en este trabajo, la gravitación de la experiencia dramática de Lope de Vega, manifestada en la elaboración de sonetos compuestos, fragmentados en diálogo de personajes que ya analizó Otto Jörder, Die Formen des Sonetts bei Lope de Vega, cit., especialmente pp. 161 y ss.

${ }^{44}$ Véase el texto correspondiente, soneto 5, p. 25 :
}

Sirvió Jacob los siete largos años, breves, si el fin cual la aspereza fuera; a Lía goza, y a Raquel espera otros siete después, llorando engaños.

Así guardan palabra los extraños, pero en efecto vive, y considera que la podrá gozar antes que muera, y que tuvieron término sus daños.

Triste de mí, sin límite que mida lo que un engaño al sufrimiento cuesta, y sin remedio que el agravio pida.

IAy de aquel alma a padecer dispuesta, que espera su Raquel en la otra vida, y tiene a Lía para siempre en ésta!

45 Véase uno de los casos más claros de isodistribución múltiple en el soneto 124, p. 97:

Blancos'y verdes álamos, un día vi yo a lucinda a vuestros pies sentada, dándole en flores su ribera helada el censo que a los suyos le debia. 
El efecto dramático es, por supuesto, mucho más poderoso en los casos de narración dramática con diálogo. Aqui la misma estructura que reparte exposición y diálogo en estilo directo, hace más fácil colegir la isódistribución dual o múltiple. L'n ejemplo extremo -en realidad uno de esos sonetos de texto doble no inusuales en Lope - sería el caso del soneto 56, donde la repartición de las dos acciones del personaje y sus dos diálogos coinciden perfectamente con el límite distributivo cuartetostercetos ${ }^{46}$. Quizá el tipo muy frecuente en Lope de textos narrativos con isodistribución dual puede representarlo el soneto $148^{47}$. En él se

Aqui pedazos de cristal corria esta parlera fuence despeñasda. - la vo\% de Narciso. enamorada. cuanto ella murmuraba repetía.

Acyui le hurtaba el vienio mil suspiros. hasta que vine yo. que los deture. porque era el blancos de sus dukes tiros.

Aqui tan loxo de mirarla estuve. que de niñas sirviendo a sus safiros. dentro del sol sin abrasarme anduve.

${ }^{46}$ Véase el texto aludido, soneto 57, p. 56 :

Silvio en el monte vio (on lazo estrecho un nudo de dos áspides asidas. que, asi enlazadas, a furor movidas. se mordian las boxas. cuello y pecho.

"Así -dijo el pastor-, que están, suspecho. en el (casado yugo) aborrecidas dos enlazadas diferentes vidas. rotas las paces, el amor deshecho.»

Por dividir los intrincados lazos. hasta la muerte de descanso ajenos. alzó el cayado, y prosiguió diciendo:

«Siendo enemigos, ¿para qué en los brazos? ¿Para qué os regaláis y os dáis venenos? Duke morir, por no vivir muriendo».

47 Véase el soneto aludido, p. 111:

Suspenso aquel divino movimiento del sol de sus estrellas celestiales. encendida la nieve en dos corales. al pie de un lauro, haciendo son el viento,

durmió Lucinda, y el Amor, atento) a la causa amorosa de mis males. dijo, alzando la voz, palabras tales. que parece que hurtó mi pensamiento:

"Venus, hermosa y duke madre mía. con Psiques andarás de nuevo en puntos: ésta es cárcel de amor, ya tengo dueño."

Oyó Lucinda lo que Amor decía. y, abrazando al rapaz, durmieron juntos. para quitarme eternamente el sueño. 
distribuye el «rol» de narrador en presentación narrativa en los cuartetos, la expresión en estilo directo en el primer terceto, y la continuación-conclusión de la narración en el segundo terceto. Responde en realidad dicho tipo narrativo a la estructura textual macrosintáctica más frecuentada en los sonetos expositivos con marcas explícitas de isodistribución dual; siendo aquí la expresión dialogal en estilo directo el equivalente de la exclamación o del imperativo de tales textos. Cuando la distribución narración/expresión directa no se produce con tan marcada regularidad distributiva, sino que por lo general el diálogo aparece ya desde los primeros versos del texto, tenemos el tipo de sonetos de isodistribución múltiple, en el que cada estrofa suele coincidir exactamente con una gran unidad-cláusula de diálogo, o con un "rol» narrativo, dialógico-directo ${ }^{48}$.

En algunos de los textos de esta índole la medida de la dramatización es particularmente evidente. Pensamos en historias de fuerte dramatismo que pasaron al propio teatro lopesco y al de sus contemporáneos, como los amores de Inés de Castro - soneto 181 «Con pálido dolor, ardiendo en ira” ${ }^{49}$ - o los de doña Blanca de Borbón, esposa de

40 Un ejemplo de tal naturaleza puede ofrecerlo el soneto 16, p. 32:

Sentado Endimión al pie de Atlante, enamorado de la Luna hermosa, dijo con triste voz y alma celosa: «En tus mudanzas ¿́quién será constante?

- Ya creces en mi fe, ya estás menguante, ya sales, ya te escondes desdeñosa, ya te muestras serena, ya llorosa, ya tu epiciclo ocupas arrogante;

-ya los opuestos indios enamoras; y me dejas muriendo todo el día, o me vienes a ver con luz escasa."

Oyblé Clicie, y dïo: «¿Por qué lloras," pues amas a la Luna, que te enfría? Ay de quien ama al sol, que solo abrasal*

"Véase el texto aludido, soneto 181, p. 131:

Con pálido color, ardiendo en ira, en los brazos de Avero y de Alencastro, de la difunta dona Inés de Castro el bravo portugues el rostro mira.

Tierno se allega, airado se retira (trágico fin de amor, infeliz astro), y abrazado a su imagen de alabastro, con eate llanto y voz habla y suspira:

«Si ves el alma, Nise, de mis ojos desde el cielo, en que pisas palma y. cedro, mas que en eate laurel y fe constante. 
Pedro I de Castilla - soneto 186 «La blanca en el valor venida a España»- En ambos casos, en especial en el primero, la presentación de la acción y los personajes, que ocupa los cuartetos, presenta los mismos móviles de patetismo que suelen configurar los dramas históricos. Textos como éstos serán ciertamente muy importantes a la hora de establecer los problemas relativos a las transformaciones textuales, de las cuales nos hemos ocupado en trabajos anteriores ${ }^{50}$, en la medida que no se trata ya del simple caso de transformación de un texto lírico en otro más o menos extenso de la misma índole, sino que se plantearía el problema a propósito de estos textos de los límites, insuperables o no, que crean los motivos de género en el seno de las transformaciones textuales.

\section{Tipología macrosintáctica y contenido temático. Analogías y diferencias}

\subsection{Mantenimiento de las estructuras macroargumentativas en sonetos de tema no amoroso}

Me propongo a continuación extender el ámbito de mis consideraciones anteriores sobre la tipología sintáctica de los sonetos amorosos a otros tipos de textos del mismo Lope de Vega, de temática distinta. Con ello pretendo examinar los posibles problemas, en torno a la importante cuestión de si la sintaxis macrotextual es o no dependiente de la semántica. Evidentemente, si para textos de contenido semántico no amoroso, como los religiosos, los conmemorativos - heroicos, históricos, fúnebres, etc.-, los morales o los burlescos en su enorme variedad de contenidos semánticos respectivos, descubrimos que Lope alteró sustancialmente las macroestructuras argumentativas de los sonetos amorosos que acabamos de tipologizar, resulta claro que la conexión entre contenido semánticotemático y estructura sintáctica es muy fuerte y determinante. Sin embargo, adelantemos desde ahora que, sustancialmente, las clases macrotextuales de construcción que hemos encontrado en los sonetos amorosos, se vuelven a dar en las nuevas ocasiones temáticas.

Evidentemente, lo anterior no excluye la vinculación determinante entre tipos sintácticos y tipos semánticos. En los capítulos anteriores hemos tenido ocasión de probar incontrovertiblemente algunas muestras de constantes de solidaridad entre estructuras de uno y otro campo. Pero

\footnotetext{
«verás que soy, honrando tus despojos, portugués en amor, en rigor Pedro, rey en poder, y en la venganza amante.*
}

so Ver el apartado correspondiente en capítulo el $\mathrm{X}$ de Janós S. Petöfi y A. García Berrio, Lingüistica del texto y crítica literaria, cit., especialmente pp. 404-423. 
tal suerte de solidaridades tienen más que ver, a nuestro juicio, con la estructura estilística pragmático-emocional conferida a cada tipo concreto de predicación, que con el contenido semántico global del mensaje. Así la apelación determina quizá más poderosamente la macroestructura sintáctica de un texto - por ejemplo, frente a la exposición sintomatica- que su contenido semántico amoroso, heroico, religioso. ets. I aun dentro de la apelación, el tipo) de énfasis (on que se la Malike. el actor aludido, etc. Análogamente el tema solemne que. por i.e.mplo. conlleva siempre en Lope el tipo sintáctico macrotextual que hemos designado de isodistribución múltiple-climax $\longrightarrow$-s decir, cuatro cláusulas independientes en isodistribución sintáctico-métrica, con un "crescendo" enfático tonal-gráfico o semántico-, se ascxia (onll igual facilidad con sonetos morales, conmemorativos o religiosos, cuvo (ontenido semanticn propio requiera o apoye tal tipo de solemnidad expresiva. En ral sentido, como veremos, tal tipo de macroestructuli: sintáctica es más frecuente, para el mismo número de textos, en el imilunto de los sonetos conmemorativos, religiosos y morales, que en los propios sonetus amorisos. De modo inverso podría decirse del tipo de sentimientos de entasis desgarrado que suele representar sintácticamente la antidistribuión untsentencial. Como tal, esta estructura sintáctica frecuentemente observada en la expresión de la temática amorosa. no se presenta apenas $-\downarrow$ en nuestra muestra nunca- en el resto de las temáticas. Lo que viene d redundar en nuestra propuesta anterior de la noción tema como conglomerado sintáctico-semántico inscrito en una determinada situacion pragmática, y no como puro sinónimo de contenido semántico, según se le usa irreflexivamente y con demasiada frecuencia en la crítica $v$ la poética lingüística.

3.0.1. Una cuestión en apariencia trivial, pero quizá en el tondo mucho más determinante sobre la dependencia de las estructuras sintacticas, es la variación que en el uso concreto de una tipología semantxad determina la propia actividad creativa de un autor en el paso we! tiempo. En tal sentido, debemos examinar por separado $-v$ muv alltell. tamente - las cuatro principales colecciones de sonetos que figuran 11 las obras líricas de Lope de Vega (hemos de reiterar nuestra advertell' 1.1 de que en nuestra muestra hemos descontado, por razones de economia de tiempo y rendimiento teórico, los sonetos incluidos en la produccion dramática de Lope). De este modo se somete a contraste la relativa universalidad de las estructuras macroargumentativas alcanzadas en nuestra tipología de sonetos amorosos en las Rimas, de 1609 , respecto no solo ، la variedad temática, sino a los cambios internos cronológicos del misino, Lope. Así se podrá afirmar o no el grado de tal unizersalidad o tipucucues 
de las estructuras sintáctico-textuales, en relación al grado correspondiente de alta topicidad de los contenidos temáticos.

Los conjuntos de textos a comparar, pues, con el esquema tipologico akanzado en los capítulos anteriores, son los cincuenta y tantos sonetos de las propias Rimas, de contenido no amoroso. Los cien sonetos religiosos de las Rimas sacras de 1614 , los cuarenta de contenido vario incluidos en La Circe, de 1624, y por último, los más de ciento sesenta sonetos burlescos, de base parodiada muy distinta, de las Rimas de Tomé de Burguillos, publicadas por Lope en 1634, un año antes de su muerte. Temas, pues, agrupados en cuatro conjuntos - regularmente jalonados cada diez años a partir de las Rimas sacras-. Quinientos poemas líricos, que constituyen la muestra más representativa posible del ingenio versátil y franco del Fénix. Con ellos podemos seguir ordenadamente la evolución creativa de Lope a lo largo de toda su existencia, y lo podemos hacer de manera más profunda que a través de meras constataciones temático-impresionistas, o de tanteos intuitivos. Junto al estudio del contenido temático de su obra, fácilmente deducible por otra parte en sus líneas generales por la índole misma de las sucesivas colecciones de poemas, podremos seguir, en los parágrafos sucesivos, la posible evolución de sus tendencias creativas manifiestas en la evolución macrosintáctica de sus textos. Con la atención puesta en dilucidar la cuestión de si incluso un temperamento tan irreductiblemente innovador como el del inquieto y genial Lope de Vega pudo o no renovar total o parcialmente los usos topificados en la tradición literaria, en lo que se refiere a la macroestructura sintáctica de los textos.

3.0.2. La respuesta a la duda anterior implica una segunda extensión de nuestra investigación, que abordamos también en este estudio. Con independencia de la observación de si Lope de Vega rompió o no el propio esquema tipológico-sintáctico inicial, que se perfila en sus Rimas a través de los años y del cambio temático, debe plantearse la cuestión previa de si la propia personalidad creadora de Lope habría partido ya de un esquema tipológico innovado o no respecto a la tradición tópica. Para tal determinación resulta imprescindible el cotejo del esquema tipológico sintáctico-textual que arroja la producción total de textos-sonetos de Lope, con un «corpus» equivalente de otros autores. En este trabajo realizaremos dicho cotejo en el apartado 4 -a partir básicamente de los sonetos de Lope de Vega, tal como se estructuran en sus Rimas - con el «corpus» que vienen a constituir los quinientos sonetos amorosos de varios autores - Garcilaso, Herrera, Quevedo y Góngora- analizado ya por nosotros en su perspectiva temática en L. T. T. L. 
3.1. Macroestructura argumentativa en los textos no amorosos de las Rimas (1609)

3.1.1. El «corpus* que vamos a examinar está constituido por un conjunto de sonetos de temática varia, que forma con los de contenido mayoritario amoroso el total de la primera colección de poesía lírica publicada por Lope de Vega en 1609, con el título de Rimas. Los índices temáticos por los que se ordenan dichos textos son: a) religiosos, apologéticos, confesionales, hagiográficos, de historia sacra; b) morales, de contenido vario; $c$ ) encomiásticos, mitológicos, de historia clásica y de personajes contemporáneos; y d) conmemorativos, fúnebres, epitalámicos, ocasionales, etc. Hemos de advertir que estas denominaciones y reparto tipológico responden de modo provisional, por ahora, solamente a la observación de los sonetos existentes en la colección de Rimas. Somos conscientes, sin embargo, de la importancia que, en una teoría general de la índole de la nuestra tiene la ponderación y recta caracterización de tales géneros y denominaciones. Por ahora, y en este trabajo, no abordaremos exhaustivamente la cuestión, que queda aplazada a futuros estudios, donde iremos examinando monográficamente la totalidad de problemas textuales lingüísticos e histórico-literarios de cada una de tales clases en concreto.

Lo primero que salta a la vista, y que nos importa adelantar ya como resultado de nuestro examen es que, salvo pequeños pormenores, la tipología macrosintáctica resultante viene a coincidir con la establecida antes para los sonetos amorosos. Teniendo en cuenta, además, la variada índole tematica del bloque de textos que oponemos globalmente a los sonetos de contenido amoroso, nuestra conclusión es tanto más representativa. sincronicamente, pues, estamos en condiciones de afirmar taxativamente la independencia funcional de las estructuras sintáctico-textuales de los sonetos respecto a su contenido temático. Dicho sea lo anterior, claro esta. con las salvedades necesarias que anticipábamos en (3.0), y que en el cuerpo de los parágrafos sucesivos iremos apuntando.

Sin embargo, tal afirmación puede resultar demasiado rotunda y generar errores. Lo anterior no quiere decir otra cosa que «en el principlu tue el sonido». Y nada menos que eso. Es decir, que según parece deducirse de nuestro análisis en la «memoria cultural o en la «experiencia de práctica artística» de un creador literario, en nuestro caso Lope de Vega, la estructura textual sintáctica elegida -como imagen melódica o/y como imagen grafémica visual-escritural- tiene un grado de independencia muy grande, por no decir absoluto, respecto del tema concreto elegido e incluso del género temático a que pertenece. Obvia- 
mente, la interdependencia estricta entre sintaxis y semántica textuales dentro del tema a lo largo de la génesis textual es otra cosa. Se trata de un debatido problema lingüístico al que no apunta de modo global y directo nuestra afirmación actual, aunque puede contribuir $-y$ así lo creemos- a esclarecer algunos puntos de dicho problema general.

3.1.2. Estructuras textuales de antidistribución y narración. Lo primero que salta a la vista en ambos casos, es el grado relativamente más infrecuente de los dos tipos estructurales dentro de los temas aquí considerados respecto a lo que eran para el género de los poetas amorosos. Concretamente no existe antidistribución unisentencial, y los cuatro sonetos registrados por nosotros como de antidistribución plurisentencial presentan quizás acrecentados los problemas de límites que ya se decantaban en la misma estructura de los sonetos amorosos, donde resulta a veces diferenciada de los textos simplemente lógico-discursivos ${ }^{51}$. La razón de esta limitación radica, como hemos señalado ya, en la indudable desacomodación existente entre el énfasis expresivo que supone la estructura textual sintáctica antidistributiva y la índole de los sentimientos enmarcados en la temática religiosa, encomiástica, moral o conmemorativa.

Respecto a la narración objetivo-representativa, ya sabemos que se trata de una peculiaridad radicalmente antilírica muy frecuentada por Lope de Vega, en especial el caso de la narración dramatizada; es decir, con la voz del personaje en estilo directo. El número de los sonetos de esta clase en Lope es sensiblemente inferior, proporcionalmente por supuesto, para estos temas que para los de índole amorosa. Sólo hemos constatado un soneto de narración dramatizada dual con estructura absolutamente tópica, el 131, De Venus y Palas, "La clara luz en las estrellas

\footnotetext{
"' Se trata de los siguientes textos: 131, dedicado al duque de Béjar, «En tanto que deshace el claro Apolo», relativamente unisentencial, manteniéndose la expresión de las circunstancias bajo la estructura-tipo del "carpe diem», en tanto quely mientras, para concluir con/con y resolución final sintagmática en los dos últimos versos: «Vuestro nombre con letras de diamente / pondrá la fama en su dorado alcázar». Los sonetos morales 137 a la noche, «Noche, fabricadora de embelecos», y 142 a Madrid, «Hermosa Babilonia en que he nacido», presentan ambos una estructura muy similar y bastante antidistributiva, por cuanto sólo en el último terceto, y tras de concluirse la sentencia básica, se agregan algunas otras frases de comentario. Claro está que el tipo temático de estos dos sonetos morales no difiere en gran medida de la clase amorosa que hacía posible la expresión enfático-indignada de los que registramos alli. Por último, el soneto a la sucesión de Felipe $I 1$ (198), a Faltaron con el tiempo riguroso», es el menos antidistributivo de todos, al ser sintácticamente el menos unisentencial. Sin embargo, la solución temática con la conclusión verdadera que inicia el símil faltaron, sólo se resuelve en el último verso. Por ello, al menos en la perspectiva semántica, nos hemos inclinado a considerarlo antidistributivo.
} 
puesta». Los demás sonetos narrativo-representativos pertenecen a la modalidad múltiple y dramatizada. Lope utilizó invariablemente esta estructura para sonetos fúnebres, como por ejemplo el 116, con expresión dialogal directa desde el segundo cuarteto, alcanzándose incluso importantísimos efectos de objetivación narrativo-dramática, al punto que, por ejemplo, el soneto 100 *A la muerte del duque de Pastrana* contiene sólo un diálogo con los distintos «roles» de actores que intervienen en la acción ${ }^{32}$; y en el soneto 194, a la muerte de Don Juan de Austria, la voz narrativa que escuchamos no es la de Lope, sino la del propio don Juan, desde el principio hasta el final del soneto ${ }^{53}$. El mismo recurso se encuentra en otro curioso soneto narrativo, éste no funerario, en el que la voz de la protagonista, Dido, se deja en primer término como un monólogo narrativo de,presentación de un auto sacramental. Soneto narrativo dual, sin otras peculiaridades, es también el 84 «De Jasón*.

52 Véase este curioso soneto, con peculiaridades pragmáticas muy destacables. Soneto 100, p. 82:

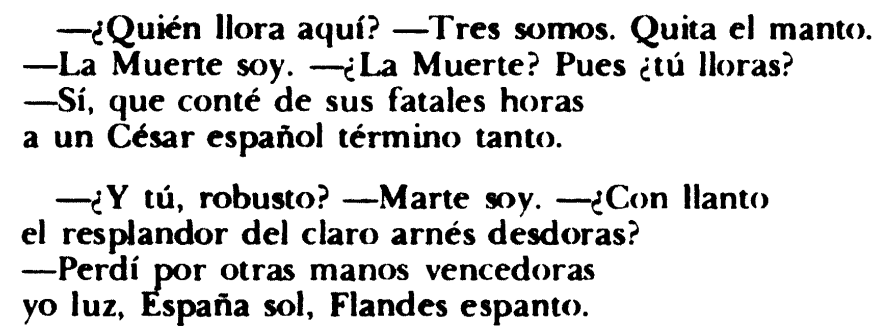

-Y tú, niño, ¿quién eres? - Antes era Amor, pero murió mi nombre y llama muerto el más bello que la fama escribe.

-Muerte, Amor, Marte, no lloréis que muera don Rodrigo de Silva: que la fama de su valor eternamente vive.

${ }^{33}$ Véase el texto aludido. Soneto 194, p. 139:

Nací en la alta Alemania, al mundo espanto, gloria a Felipo, a Carlos esperanza. viví en España humilde entre labranza, que rayo de tal sol encubrió tanto.

Para bañar el moro en sangre y llanto, tomé en Granada la primera lanza, y en cuanto la memoria humana alcanza, la vitoria mayor gané en Lepanto.

Rompí a Túñez; vencí, volviendo, a Flandes, mil guerras, mil rebeldes, mil engaños, y tuve de ser mártir santo celo.

No quise a Irlanda con promesas grandes, muero en Bouges, vivi treinta y tres años, fui César de la fe, triunfé en el cielo. 


\subsubsection{Estructuras textuales en isodistribución}

3.1.3.1. Isodistribución múltiple. Once sonetos de este tipo en sus dos variedades, vario y climax, hemos encontrado, lo que supone un alto porcentaje para la reducida muestra con que nos movemos, desde luego porcentaje superior al de los amorosos que testimonia ya el comienzo de la evolución estilística de macroconstrucción atestiguable en Lope. Se trata, por lo demás, de una estructura rítmico-sintáctica que Lope elegía frecuentemente para tratar los temas más solemnes, con lo que se explica la elevada concentración de estructuras de esta índole entre los sonetos de contenido moral, conmemorativo, fúnebre, etc. Los textos de isodistribución múltiple están representados en todos los dominios: moral, con su soneto a la muerte, 199; encomiástico, el soneto 157 al doctor Arjona y el 176 al duque de Osuna ${ }^{\text {s4 }}$. La historia bíblica viene representada por uno de los sonetos de rimas dificiles y peregrinas, a base de nombres hebraicos, de que tanto gustaba Lope, el 200, y que es sólo en realidad una sucesión de endecasílabos independientes entre sí. Por último, el soneto 86 representa la historia mitológica.

El tipo de sonetos que denominamos de climax, presenta aquí casos de dificil atribución respecto de las clases estructurales afines, como es la misma múltiple-vario o la dual-mixto. En los sonetos encomiásticoconmemorativos de esta clase que hemos censado se produce idénticamente la gradación o la simple elevación final de la sorpresa, a base de juego semántico-conceptual, sin las marcas exclamativas o enfáticas que veíamos se producían regularmente en los amorosos ${ }^{55}$. Más típicos, en este sentido, son los textos de contenido moral que representan esta

s4 Véase el texto aludido como ejemplo del tipo de sonetos que estamos comentandk. Soneto 176, p. 128:

En láminas de plata, en letras de oro, que en almas escrebirse merecía, vuestro nombre a la fama el mundo envia, Girón divino, del mayor tesoro.

Será sujeto del Castalio coro, mientras dura del cielo el armonía, famoso en cuanto el sol dilata el día, del Pez al Cancro, de la Libra al Toro.

Verá la envidia en la mayor alteza, de tútulos tan grandes escogido, el del ingenio fertil y abundante.

Igualará la pluma a la grandeza. y el Parnaso, de vos favorecido, tendrá en su frente el cielo como Atlante.

ss Se trata de los sonetos: 24, a Carlos V, «Del templo de la Fama en alta parte»; 38, al Duque de Osuna y Conde de Ureha, "El Tiempo, a quien resiste el tiempo en vanow, y 193, a la encamisada del Principe nuestro sefor, "Desata el capirote y la pigüelas». 
estructura, como el 53 sobre el paso del tiempo, o el 154 dedicado a la Verdad ${ }^{36}$.

3.1.3.2. Isodistribución dual sin marcas. Como hemos señalado ya, dentro de esta clase se distinguen dos tipos de textos, aquellos en los que existe un cierto paralelismo constructivo subrayado por la reiteración de algún elemento léxico, o enfático o temático, y aquellos otros en los que tal paralelismo, que desemboca en distribución dual, es organizado de modo menos evidente y a través de deixis internas textuales explícitas sobre bases de cambios en la modalidad expresiva narrativa, expositiva o apelativa, distribución de "roles» temáticos. etc. A la primera clase pertenece un crecido número de textos de todo tipo. La estructura básica es la que representaríamos como $a / b / / a / b$; con ella se construye el soneto 120 a don Francisco de Quevedo, ordenado a través de la oposición explícita vos/yo // vos/yo; el 168 al doctor Tejada, con estructura explícita: Por vos + vocativo/oiráse // Por vos + vocativo/humillaráse; o el 178, a la sepultura de su hija Teodora de Urbina, organizado del siguiente modo: Vocativo/mas $d$ ? // Vocativo/mas i!/. También es alternativa, la construcción del soneto 49 al duque de Alba y del 54 a Pedro Liñán. Otro tipo de estructura paralela que querríamos señalar es la del soneto 196 «Al casamiento de Felipe tercero y Margarita de Austria nuestra señora», básicamente consiste en la concentración en el centro del soneto $\mathrm{a} / \mathrm{b} \mathrm{b} / \mathrm{b} / \mathrm{c}$ - segundo cuarteto y primer terceto- de un bloque dual con paralelismo muy marcado, que aísla y deja libres, por tanto, el comienzo y el final del texto. Se trataría casi de una excepción a la distribución dual ${ }^{57}$. Si lo destacamos aquí es porque lo hemos encontrado igualmente con frecuencia entre los sonetos amorosos.

\footnotetext{
56 Véase este texto como muestra de dicha estructura, soneto 159, p. 117:

Hija del Tiempo, que en el Siglo de Oro viviste hermosa y cándida en la tierra, de donde la mentira te destierra en esta fiera edad de hierro y lloro.

Santa Verdad, dignísimo decoro del mismo cielo, que tu sol encierra; paz de nuestra mortal perpetua guerra, y de los hombres el mayor tesoro;

casta y desnuda virgen, que no pudo vencer codicia, fuerza ni mudanza, del sol de Dios ventana cristalina;

vida de la opinión, lengua del mundo; mas ¿qué puedo decir en tu alabanza, si eres el mismo Dios, Verdad divina?

${ }^{57}$ Véase el texto indicado, soneto 196, p. 140:

Las águilas de Carlos soberano, el gran Filipo en cielo convertido,
} 
Como caso muy singular de estructura dual en paralelo mencionaremos al fin un grupo de sonetos de Lope, en los que indudablemente la estructura sintáctica propicia y refuerza el contenido temáticosemántico. Se trata de sonetos que son en realidad el resultado simple de la adición de dos textos con temas similares. Como ejemplo más característico recordaríamos el soneto 76 De Pompeyo y César con la estructura $\mathbf{a} / \mathbf{b} / / \mathrm{a} / \mathbf{b}$ siguiente: Vocativo (Pompeyo)/ ? // Vocativo (César)/ ¿? \$. Un texto relativamente idéntico sería el soneto encomiástico 144 "A don Félix Arias Girón». Este con un sólo sujeto, pero con un confidente, el Océano, que ocupa la distribución de los primeros cuartetos. Por lo demás, se mantiene idéntica estructura: Voc. (Océano)/ Imperat. // Vocativo (Girón)/Imperat. Como decimos, Lope cultivó con trecuencia estos casos de duplicación temática en el mismo soneto, generalmente para contrastar bajo algún aspecto las dos figuras que elegía. Recordemos, junto a los anteriores, los ya analizados, con diferente estructura; 38 al Duque de Osuna y al Conde de Ureña, el 130 de Venus y Palas, y el 116 de Codro y Pompeyo. En ocasiones también la estructura paralela se combina con la posibilidad de relacionar y compa-

\footnotetext{
quieren sobre un castillo hacer su nido, en la mitad del corazón hispano.

Ya de Clemente la sagrada mano el cuello tiene al yugo de oro asido, y con su bendición divina ungido, para colunas del valor cristiano.

Ya de diamantes, perlas y esmeraldas cetro imperial adorna su alta frente, que España ofrece en sus preciosas faldas;

pero queda el blasón tan diferente, que sus águilas siempre están dé espaldas, y éstas han de mirarse eternamente.

38 Ver el texto mencionado, soneto 76, p. 68 :

Sufre la tempestad el que navega, el enojoso mar y el viento incierto con la esperanza del alegre puerto, mientras la vista a sus celajes llega.

En la Libia calor, hielo en Noruega, de sangre de armas y sudor cubierto, sufre el soldado; el labrador, despierto al alba, el campo cava, siembra y riega.

El puerto, el saco, el fruto, en mar, en guerra, en campo, al marinero y al soldado y al labrador anima y quita el sueño.

Pero triste de aquel que tanto yerra, que en mar y en tierra, helado y abrasado, sirve sin esperanza ingrato dueño.
} 
rar los dos temas, como en el caso del soneto 177, De Abel y Josef ${ }^{\text {sy, }}$ con estructura: Narración (Abel)/Narración (Josef) // Agrupación, intratextual Abel, José (allí)/ Antítesis conclusiva Abel-José.

Entre los sonetos del tipo de estructura paralela con agrupación intratextual, la variedad de principios semántico-pragmáticos estructurantes es muy grande, pero en todos los casos la macroestructura textual argumentativa resultante es muy semejante, con clara bipartición por lo general, entre los cuartetos y los tercetos. Así el soneto 17, encomiástico a Guzmán el Bueno, registra la repartición entre narración/apelaciónaplicación. El 48 «El pastor que en el monte anduvo al frio», se reparte entre el «rol» del pastor y el del propio poeta en exposición sintomática. El soneto 74, al Conde de Lemos, se construye sobre la oposición de la antigüedad-sus maravillas/la edad española actual-los sonetos del conde. El 85, al mártir inglés Tomás Porcey, establece la contraposición apelativa entre la vida/muerte del conde. Un caso muy claro de este tipo es la contraposición entre descripción y apelación, perfectamente encuadradas entre las dos mitades rítmico-sintácticas del texto, en el soneto 104 a Absalón ${ }^{60}$. Otro soneto más dudoso con esta estructura sería el 111 a don Alvaro de Guzmán.

s9 Ver el texto mencionado, soneto 177, p. 128:

Sangrienta la quijada, que por ellas Adán comenzó a ser inobediente, Caín deja mil bocas en la frente del tierno Abel, para formar querellas.

Tiran del manto de Josef las bellas manos de una mujer $y$, de impaciente, por adúltero prende al inocente que cegó con la capa las estrellas.

Alli los padres muerto al mártir vieron; allí al vendido, en carro de oro, el año estéril, los hermanos piden trigo.

Muere Abel, Josef triunfa, porque fueron, Caín hermano y faraón extraño, y no hay cuchillo como el propio amigo.

${ }^{60}$ Ver el texto mencionado, soneto 104, p. 84:

Suspenso está Absalón enıre las ramas que entretejen sus hojas y cabellos, que los que tienen la soberbia en ellos jamás expiran en bordadas camas.

Cubre de nieve las hermosas llamas, al eclipsar de aquellos ojos bellos, que así quebrantan los altivos cuellos las ambiciones de mayores famas.

¿Qué es de la tierra que usurpar quisiste?

Pues apenas la tocas, de liviano, bello Absalón, famoso ejemplo al suelo. esperanza, ambición, cabellos diste al viento, al cielo, a la ocasión; tan vano; que te quedaste entre la tierra y cielo. 
3.1.3.3. Isodistribución dual con marcas. Como recordaremos, el cuerpo básico de estos tipos puede establecerse en torno a la naturale va de las marcas de distribución: enfáticas, a base de límites creados por vocativos, exclamaciones $e$ interrogaciones enfáticas, y lógico-conectivias, es decir, textos de discurso bien trabado y escindido a base de relaciones de solidaridad sintáctica, debidamente subrayadas por conectores y separadores lógico-gramaticales. Como en los amorosos, también en estós temas el número de los enfáticos es notablemente superior en las Rimas divinas de Lope al que se puede registrar en otros poetas. Los discursivos, ricos en conectores lógicos, son en su totalidad conmemoratizios, o encomiásticos. Por ejemplo el 51 , con motivo del traslado de la corte a Valladolid, el 67 a doña Laura de Guzmán, discursivo y conceptuosamente encomiástico, como también lo es el 107 a don Juan de Austria; el 120 «A don Juan de Arquijo, viendo un Adonis, Venus y Cupido de mármol»; el 165, al doctor Mira de Amescua, que podriamos proponer como ejemplo de esta estructura con conectores explícitos ${ }^{61}$. Por último, es de este mismo tipo el oscuro y defectuoso soneto 169, "A don Felipe de Africa».

Dentro de la clase de los sonetos con marcas enfáticas, podemos apreciar aquí en primer lugar dos sonetos híbridos, con fuerte énfasis de vocativo en primer término, pero muy construidamente lógicodiscursivos en los tercetos, que no dudamos, por tanto, en clasificar dentro del grupo anterior. Se trata de los sonetos 15, conmemorativo a la batalla de Africa, y el soneto semiburlesco 47, a un retrato. Entre los específicamente enfáticos encontramos también aquí no sólo el tipo general de la clase, sino aun las mismas subclases combinatorias que se producian más frecuentemente en los amorosos. La combinación vocativo/imperativo se registra tanto en sonetos solemnes conmemorativos,

${ }^{61}$ Ver texto aludido, soneto 165. p. 121:

Viendo que iguala en su balan

los rayos y las sombras desiguales.

Dauro no ha reparado en las señales de la extranjera vega que pasea.

Mas ya que el oro que le dais emplea en mis arenas, a la Libia iguales. fkorecerán mi vega sus cristales. y vos mi ingenio, de mi mundo idea.

A que sois primavera me resuelvo, por quien las flores que perdi restauro: tal abundancia vestro ingenio cría.

$Y$ asi, en tanto que al patrio Tajo vuelio, serán entre las márgenes del Dauro las flores vuestras y la vega mía. 
como el 46, dedicado «a la jornada de Inglaterra* ${ }^{62}$, como en otros intrascendentes, en principio, puramente ocasionales, tal como el 121, «A una Venus de mármol», o profundamente morales como uno de ks famosos poemas sobre el tema de la «barquilla», el soneto 150, «Pobre barquilla mía, que arrojada».

La combinación de vocativos, o expresiones análogas fuertemente apelativas, en los cuartetos con fórmulas de énfasis exclamativo o interrogativo en los tercetos, con un resultado imaginablemente patético, sirve de soporte a Lope para la expresión de algunos de sus más vehementes y sinceros textos funerarios, como el soneto. 147, « A la muerte de don Juan de Ulloa, conde de Villalonso», o el dedicado a la muerte de Felipe $1 I^{63}$. Pero quizá los más significativos textos sean los que Lope dedicó a la memoria de sus amores entrañables, como el 163, a la muerte de su padre. Por último, el tipo dual de expresión lógico-conectada en los cuartetos con exclamaciones enfáticas en los tercetos da lugar a kos

62 Ver el texto aludido, soneto 46, p. 50:

Famosa armada de estandartes llena, partidos todos de la roja estola. árboles de la fe, donde tremola tanta flámula blanca en cada entena;

selva del mar, a nuestra vista amena, que del cristiano Ulises la fe sola te saca de la margen española. contra la falsedad de una sirena,

id, y abrasad el mundo, que bien llevan las velas viento, y alquitrán los tiros. que a mis suspiros y a mi pecho deban.

Segura de los dos poxdéis partiros. fiad que os guarden, y fiad que os muevan: tal es mi fuego, y tales mis suspiros.

${ }^{63}$ Véase el texto como ejemplar expresión de la estructura que comentamos, soneto) 197, p. 141:

Humillense a su sacro mausoleo, fuerte David y Salomón prudente. el rebelde gigante del Oriente

y el idólatra del contrario polol y a tu pendón crucígero, que sólo, fue del Africa y Asia rayo ardiente. cuantos beben la bárbara corriente de Eufrates, Nilo, Ganges y Pactok.

La religión y la justicia lloren, joh pacífico Numa, oh gran Torcato! España, Italia y Francia enternecida.

Todos juntos nüevamente adoren encima de tus aras, tu retrato, tercero entre tu muerte y nuestra vida. 
sonetos 20, «Si culpa, al concebir; nacer tormento» ${ }^{44}$; 22, «Para tomar de mi desdén venganza», y 145 , dedicado al Marqués de Malpica.

\subsection{La tipología macrosintáctica en textos de contenido no amoroso. Las «Rimas sacras» (1614)}

3.2.1. Componen el conjuntơ de esta colección de poemas, además de un elevado número de romances y otras composiciones, cien sonetos. El problema central que nos ocupará en las páginas inmediatas será el de comprobar si las macroestructuras sintáctico-textuales de estos textos tienen o no correspondencia con los que hemos tipologizado ya en Mas Rimas. En todo caso, atenderemos muy prioritariamente a señalar las peculiaridades encontradas que, como hemos dicho antes, pueden deberse tanto o más al simple hecho del paso del tiempo y al perfeccionamiento estilístico del autor, que a la determinación de las estructuras sintácticas textuales como consecuencia del cambio temático-semántico. De todos modos, nuestra exposición será ya deliberadamente mucho más rápida, pues los tipos generales de construcción textual en los sonetos han sido ya descritos en los capítulos precedentes, lo que nos exime aquí de otra cosa que no sea la simple mención.

Adelantamos que también aqui se repiten las mismas macroestructuras sintáctico-textuales que hemos visto establecidas para los sonetos amorosos. $\mathrm{Ob}$ viamente aparece alguna forma peculiar que Lope no había ensayado quizá hasta este conjunto de poemas, como el soneto enfático-discursivo, cuya justificación abordaremos aquí no sólo desde la perspectiva del experimentalismo creativo de Lope en el transcurso del tiempo, sino como posible exigencia de la misma temática tratada. Pero, insistimos una vez más, las grandes líneas de la tipología no se verán alteradas. Las

64 Véase el texto indicado como ejemplo, soneto 20, p. 35:

Si culpa, el concebir; nacer, tormento; guerra, vivir; la muerte, fin humano; si después de hombre, tierra y vil gusano, y después de gusano, polvo y viento;

si viento, nada, y nada el fundamento; flor, la hermosura; la ambición, tirano; la fama y gloria, pensamiento vano, y vano, en cuanto piensa, el pensamiento,

¿quién anda en este mar para anegarse? ¿De qué sirve en quimeras consumirse, ni pensar otra cosa que salvarse?

¿De que sirve estimarse y preferirse, iuscar memoria habiendo de olvidarse, y edificar, habiendo de partirse? 
macroestructuras sintácticas de estos textos manifiestan, una vez más, su relativa independencia del contenido semántico macrotextual.

3.2.2. El tema religioso, por lo demás, encierra para Lope básicamente tres tipos de composiciones: las de confesión, sintomáticas o apelativas a Dios, en las que el poeta manifiesta los lazos que lo vinculan a la divinidad, proclama su fe en ella o confiesa sus culpas; las de historia bíblica, y las hagiográficas. Las primeras son, sin duda, las más frecuentes o interesantes. Sin pretender agotar aquí el análisis que hemos de hacer en trabajos futuros sobre la estructura temática de la lírica religiosa clásica, digamos que, si en cuanto a las estructuras sintáctico-textuales, Lope tomó sencillamente las que existían en la propia tradición de la lírica amorosa, en cuanto a las pragmático-semánticas la vía no es muy distinta. En efecto, los que hemos llamado nosotros sonetos de "confesión", constituyen un caso evidente de traducción directa y simple a la temática religiosa de las fórmulas poemáticas a través de las cuales se encarnaba tópicamente un sentimiento fundamental distinto del religioso, que era el amoroso cortés. De sobra es conocida la tradición clásica de confeccionar poemas «a lo divino" sobre la base del cancionero amoroso de algún autor admirado, singularmente en España Garcilaso de la Vega. Por si se nos olvidaba, además, Lope pone al frente de sus Rimas sacras un poema *a lo divino», el famoso soneto de amor quejoso de Garcilaso «Cuando me paro a contemplar mi estado 64 bis. En la confesión religiosa se tematiza el amor a Dios, como en la amorosa el amor a la dama, y dicha tematización se lleva a cabo en los mismos términos sintácticos y semánticos que en el caso de la lírica amorosa.

Las distintas modalidades temático-semánticas que registra el soneto de confesión equivalen, básicamente, a las diferentes modalidades temáticas del amor cortés. La fórmula inicial no cambia, aquí será:

$$
[\varphi]\{a / \text { poeta, o/Dios }\}
$$

para $\varphi$, amar. La proclamación positiva de dicho sentimiento amoroso, que en los sonetos amorosos era el canto es aquí la confesión, en su sentido más genuino de proclamación, que en último término podrá designarse simplemente proclamación o canto. Obviamente no actúan idénticamente en la temática religiosa las presuposiciones inmediatas a la fórmula inicial que operaban en la amorosa - L. T. T. L. 3.1.1- La dama, a veces o casi siempre, no amaba al poeta. Situación que, en

64 bis Estudio exhaustivo de este rasgo muy frecuentado en general por Lope se encuentra en Otto Jörder, Die Formen des Sonetts bei Lope de Vega, cit., pp. 219 y ss. 
principio, parece no darse en el caso de la poesía religiosa. Sin embargo, sobre todo en la obra de Lope, lo que se tematiza con frecuencia son las consecuencias del pecado precisamente como pérdida del amor de Dios. Como se ve, pues, las equivalencias actanciales son gemelas. Si existe la rama positiva, el canto, como proclamación o confesión, existe la rama negativa en estos textos religiosos. La queja y el sufrimiento son, por tanto, equivalentes absolutos entre la poesía amorosa y la religiosa. Recuérdese, por lo demás, aparte de los datos indicados antes, que en la tradición lírica de las literaturas europeas modernas, concretamente del dolcestilnovismo y la poesía trovadoresca, el paso del tema amoroso al tema religioso, a través de la dama-María, está perfectamente constatado. $Y$ en el sentido opuesto, lo está igualmente la simbolización del endace del alma con el creador a través de la unión amorosa. Esta dentro de la tradición del Cantar de los Cantares.

Naturalmente la expresión de la queja en la lírica confesional-religiosa no puede registrar cauces tan variados como en la lírica amorosa. La triple rama especializada por el actante-término: dama/Amor/poeta mismo. Se reduce sólo aquí a la queja del poeta contra sí mismo, por sus propias culpas. Cuando mucho, si en el caso de Lope aparece alguna vez la mujer quejosamente asociada al propio pecado, ni siquiera entonces desplaza temáticamente la queja del poeta mismo. Respecto al sufrimiento, conviene no olvidar cómo veíamos en $L$. T. T. L. que tal estructura temática y la queja constituyen derivaciones de una misma base de presuposición. La única diferencia entre ambos predicados, respecto a la representación semántica del predicado-presuposición básico, se deriva de la presencia o grado cero. Por consiguiente, cuando la contricción, o queja religiosa por amor, no revierte explícita y temáticamente sobre la declaración de culpas, sino sobre el estado dolorido por la ausencia del amor de Dios, podemos hablar de sufrimiento en la lírica amorosa.

En este mismo paralelo inicial, que estamos bosquejando aquí, entre la estructura de la poesía religiosa y la de otros géneros poéticos, no resulta dificil imaginar la inmediata vinculación existente entre las otras dos modalidades de poesia religiosa -al menos entre las que Lope cultivó genéricamente- y la poesía encomiástica y conmemorativa. Los poemas hagiográficos, o las composiciones a fiestas de Cristo o de la Virgen constituyen el equivalente de los sonetos encomiásticos y conmemorativos. Respecto a los temas de historia biblica constituyen la contrapartida histórica de la temática anterior en el mismo grado que los de historia clásica constituian el equivalente de los celebrativos.

3.2.3. Macroestruaturas sintócticas de la narración. Ausencia de textos antidistributivos. Hechas ya las indicaciones precedentes, que ponen de 
manifiesto la identidad estructural de la tipología temática entre la poesía amorosa y la religiosa, nos ocuparemos de examinar brevemente las correspondencias y peculiaridades - cuando existan- entre ambas temáticas en el plano sintáctico-macrotextual. La primera indicación a hacer es que Lope no utiliza en estos temas nunca la estructura de antidistribución. Posibilidades de vehemencia expresiva no faltaban al sentimiento religioso, sobre todo en el grado de permanente contricción en que la cultivaba Lope; pero sin duda la estructura sintáctico-semántica estaba ya demasiado bien fijada como temą amoroso en la tradición para hacer desistir a Lope de su uso por razones de respeto referente al tema.

En cuanto a textos narrativo-objetivos, la clase está muy bien representada, dieciocho sobre una muestra de cien sonetos. La narración múltiple es, con todo, la menos presente, sólo un texto con dramatización, el 53 «Al Santísimo Sacramento», y aun en este caso la presencia de la expresión directa es muy escasa y englobada en la estructura general narrativa. La narración no dramatizada sirve de soporte a Lope en la -temática de su propio pasado pecaminoso, en el soneto 24 , «En estos prados fértiles y sotos», y de su arrepentimiento en el 45, «Levantareme 'de la seca tierra». Pero también brinda la ocasión para sonetos hagiográficos, como el de San Sebastián, 62, y a Teresa de Jesús, 74.

La narración dual está mucho más presente en Lope. A la clase no dramatizada corresponden los sonetos hagiográficos y de historia sa'grada siguientes: 64, "Por celebrar, Domingo, soberano», el 70 a San Martín, el 78 y el 79 sobre los mártires españoles Justo y Pastor, y Santa Engracia, respectivamente; y el 95 de historia bíblica sobre el encuentro de Isaac y Rebeca, «Formando Batüel castillos de oro". La clase más numerosa de sonetos religiosos narrativos está constituida por los de estructura dual-dramatizada, aun cuando quizá debe indicarse como rasgo general de Lope la progresiva desaparición de sonetos de este tipo. Respecto al gran número de los existentes en las Rimas, y sobre todo respecto a la extensa presencia en ellos de la voz del personaje en estilo directo, las Rimas sacras ofrecen una limitadísima muestra. En casi todos los sonetos que hemos registrado, la presencia de la voz,raramente sobrepasa un solo verso ${ }^{65}$. Registra alguna muestra de dramatización de

"S Como ejemplo más puro del tipo, y donde el coloquio se ve más representado, proponemos el ejemplo del soneto 93 sobre Abraham, p. 366:

Bajaba con sus cándidas ovejas por el valle de Aram Raquel hermosa, el oro puro y la purpúrea rosa mezclando las mejillas y guedejas, 
esta indole, como se recordará, el famoso soneto híbrido, a la vez sintomático-apelativo y narrativo «:Qué tengo yo que mi amistad procurasì». como también el soneto de proclamación y confesión 30. Por bo demás los ejemplos más característicos son los hagiográficos, como el 68 sobre María Magdalena, el 76 a San Simón Carmelita, alternando con ambos la estructura descripción/situación/acción, o el animado soneto conmemorativo sobre la visita de la Virgen, 88, «El cabello tendido por el mant(o». Se registran también, dentro de esta clase, los sonetos de historia bíblica 92 y 93, ambos con la típica estructura antes indicada descripción-situación/acción.

\subsubsection{Textos con estructura isodistributiva}

3.2.4.1. Isodistribución múltiple. Se trata de una clase muy bien representada en los sonetos religiosos. En efecto, el énfasis solemne y respetuoso que puede ofrecer este tipo textual sintáctico en apelación fue frecuentemente aprovechado por Lope de Vega, a diferencia de otras estructuras enfáticas ya examinadas; como las de la antidistribución, o incluso la dramatización extensa, que Lope fue progresivamente abandonando. En el grupo de los sonetos normales dentro de esta clase encontramos: Soneto 7 «¿Quién sino yo tan ciego hubiera sido?», apelativo del poeta a sí mismo con cuatro cláusulas interrogativo-enfáticas. Expositivo-sintomáticos son el 13, «Engaño es grande contemplar la suerte», y el 99, "No espanta al sabio, ni ha de ser temida», dos estructuras sintácticas muy semejantes que sirven un mismo tema: la muerte, contemplada precisamente en la perspectiva moral inmortalizada por Quevedo bajo la forma tópica de la cuna y la sepultura ${ }^{66}$. Sonetos apelativos a la Divinidad son el 22, "Yo dormiré en el polvo y si

\footnotetext{
ellas lamiendo) a la canal las tejas. y ella mirando el prom) cuidadosa. anticipóse a levantar la losa el que fue mavorazgo por lentejas.

Bebió el ganado caluroso, y luego diola beso de paz. y por despojos lágrimas que lloró perdido y ciego.

Muy tierno sois. Jacob. :Tan presto enojos? Sí, que en llegando al corazón el fuego. lo que tiene de humor sale a los cjoss.

66 Véase en el soneto 13 esta coincidencia temática. p. 322:

Engaño es grande contemplar de suerte toda la muerte como no venida. pues lo que ya pasó de nuestra vida no fue pequeña parte de la muerte.
} 
mañana»; el 23, «Nunca me vi tan lejos de temeros»; el 28, «Vos conocéis, Señor, la compostura», y el 90, «Nuevo ser, nueva vida, aliento nuevo». Apelativos a diferentes santos son los sonetos 88, 97 y 98 . Mencionemos, como último de esta clase, el soneto 35, «Principios de virtud que no sabía», expositivo-sintomático con un confidente, Elisio de Medinilla, invocado en vocativo. Caso sin duda especial, pues la figura del confidente, tan frecuente en los temas amorosos, no suele darse entre los sonetos religiosos.

Muy numerosos también son los poemas de este tipo que presentan la peculiaridad de cerrar el texto de modo enfático, es decir, en un clímax. Buena muestra de esta clase es el soneto sintomático 3, «Entro en mí mismo para verme, y dentro». En el soneto 9 es precisamente el clímax creado por la exclamación y el tránsito súbito de la narración a la expresión sintomática vehemente en el último terceto el que configura definitivamente la construcción estructural del texto. El síntoma, en expresión vuelta hacia sí misma, constituye el tipo de texto apelativo al mismo poeta, como es el caso del soneto 10, « ¿Sería bien aguardar, cuerpo indiscreto?». Otros sonetos apelativos de término normal, Dios -directamente o bajo alguna transfiguración-, son el 14, «Pastor, que con tus silbos amorosos», y 39, «Si es tanta gloria estar a los umbrales». Como texto típico de esta estructura proponemos el conocido soneto deíctico-anafórico, "A una calavera* ${ }^{67}$.

Con excepción se dici, puesto que es fuerte. de morir el vivir, mas ya vencida no deja que temer, si prevenida, mientras vivimos, en morir se advierte.

Al que le aconteció nacer, le resta morir; el intervalo, aunque pequeño. hace la diferencia manifiesta.

La muerte, al fin de cuanto vive dueño, está de dos imágenes compuesta: el tiempo, antes de nacer, y el sueño.

"Véase el conocido texto, soneto 43, p. 337:

Esta cabeza, cuando viva, tuvo sobre la arquitectura destos huesos carne y cabellos, por quien fueron presos ks ojos que, mirándola, detuvo.

Aquí la rosa de la boca estuvo, marchita ya con tan helados besos; aquí los ojos de esmeralda impresos, color que tantas almas entretuvo.

Aquí la estimativa en que tenía el principio de todo el movimiento, aqui de las potencias la armonía.

iOh hermosura mortal, cometa del viento!, ¿donde tan alta presunción vivía desprecian los gusanos aposento? 
3.2.4.2. Isodistribución dual sin marcas. Ya hemos indicado cómo en este grupo de sonetos, especialmente en hs que hemos denominado con agrupaciones intratextuales, se incluye un nutrido grupo de textos de no fácil catalogación, pues precisamente su característica es la ausencia de marca explícita. Su principio organizativo básico, el paralelismo dual bajo el que se descubre la voluntad de construcción textual del autor, puede consistir, por otra parte, en la contraposición orgánica de muy distintos tipos de categorías. Casi siempre se trata de la fórmula opositiva de distintos planos narrativos o "roles" personales. Asi, el soneto 36, «Sobre ocho veces treinta el sol corría", con la oposición " rol» narrativo-tercera persona/ rol" expositivo-sintomático. Los sonetos 42 y 51 oponen también narración exposición a apelación, y el 48, narración a exposición, a través de la fórmula de transición explícita así yo. El 55 , "A la decensión de Nuestra Señora" opone una descripción pictural, verdadero cuadro auditivo barroco, a la presentación dinámica de los personajes de la acción ${ }^{6 *}$. En el soneto 94, "Yo pagaré con lágrimas la risa", la distribución se realiza mediante la contraposición de la expresión del amor carnal en los cuartetos y la del amor a Dios en los tercetos, análogamente el 19 sobre la propia poesía amorosa y religiosa.

Entre los sonetos de paralelismo explícito mencionaremos, en primer lugar, los que presentan la combinación más segura y usual, a saber: $\mathrm{a} / \mathrm{b} / / \mathrm{a} / \mathrm{b}$, por ejemplo, el soneto 29 , «Luz de mis ojos, yo juré que había" - vocativo/discursivo // vocativo/discursivo-; el 34, "Llamé mi luz a la tiniebla oscura», con estructura: exposición-exclamación finalexclamación // exposición-exclamación final-exclamación; o el 86, «Todos te pintan encarnado y blancon, con distribución explícita (encarnadoblanco)/pero // (encarnado/blanco)/pero. Otro tipo de distribución para-

\footnotetext{
muy comunes en el arte barroco, soneto 5.5. p. 344:

Cuelgan racimos de angeles que enrizan la pluma al sol en arcos soberanos humillan nubes promontorios canoss. y de aljofiar la tierra fertilizan.

Desde el cielo a Toledo se entapizan los aires de celestes cortesanos con lirios y aacenas en las manos. que la dorada senda aromatizan.

Baja la Virgen, que bajo del cielo al mismo Dios; pero si a Dins Maria. hoy a María de Ildefonson el celo.

Y como en pan angélico asistia Dirs en su iglesia. el (ielo vio (que el sueks ventaja por entonces le tenía.
}

on Véase el texto) aludido como significativa muestra de t(endencias estilistico-culturales 
lela, del que ya hemos destacado su condición en cierta medida antidual, es la geminada en el centro $\mathrm{a} / \mathrm{b} / / \mathrm{h} / \mathrm{c}$, tipo que representa el soneto $\mathbf{3 8}$, con geminación si/si, y el 83, con geminación paralela enfática, o los sonetos de construcción en «espejo» a/b // b/a, tales como el 32 o el 61, y el 80 , con un centro biclausual expositivo y narrativo, respectivamente, flanqueados de cláusulas enfáticas inicial y final ${ }^{69}$.

3.2.4.3. Isodistribución dual con marcas. Escasas peculiaridades singulares presentan los textos de discurso lógico-conectado sobre las condiciones generales de su estructura descrita ya por nosotros sobre la muestra de las Rimas. Se trata de los sonetos $1,44,60,69,81$ y 96 . Otro tanto sucede con los que hemos denominado mixtos entre las formas no enfáticas y las enfáticas, su nómina simple es: 6,15 y 67 con imperativo en último terceto, y 56 con apelación.

Dentro de la modalidad de isodistribución dual con marcas, ofrecen mucho mayor interés, sin duda, los sonetos enfáticos. Ya sabemos hasta qué punto había explotado Lope este tipo textual en los sonetos, amorosos y no amorosos, de las Rimas; en lo que se refiere ahora a los textos religiosos, tanto por su número como incluso por las alteraciones estructurales de algún tipo concreto de textos, daríamos también la primacía en interés a esta clase de macroestructuras semánticas, por lo que se refiere a las Rimas sacras.

Comenzando por la tan frecuentada combinación apelación enfática en vocativolapelación en imperativo, se registran ocho títulos en los sonetos religiosos ${ }^{70}$, de los que proponemos como modelo el soneto 8 , « $\mathrm{Oh}$ cora-

${ }^{69}$ Véase como ejemplo el soneto 61, p. 347 :

Poned la limpia mesa a Cristo, y coma. espíritus divinos, del cordero, de cuyo sacrificio verdadero el humo sube en oloroso aroma.

Color de rosa en las parrillas toma; sazón le ha dado amor, servidle entero; vuele a mejor Arabia y hemisfero deste fénix la cándida paloma.

Está sin corazón, asóse presto. y que le vuelvan de otro lado avisa, para llevar mejor el fuego impreso.

Angeles, si la mesa le habéis puesto, decilde que la carne coma aprisa, que el más cristiano Rey espera un hueso.

${ }^{70}$ He aqui la nómina de los títulos propuestos: 8 , “ ¡Oh corazón más duro que el diamante!»; 37, « ¡Con qué artificio tan divino sales! ; 40, « $O$ Oh quién muriera por tu amor ardiente»; 50, "Los que fuera del curso y armonía; 66, «edro, a la sangre que por nos vertida»; 73, «Oh vida de mi vida! ¡Cristo santo!»; 75, *Aguila, cuyo pico soberano»; 100 , «Cuándo en tu alcázar de Sión y en Beth». 
zón más duro que el diamante! "'. Bien representada también, con siete textos, se nos of frece la combinación apelación enfítica en rocativo/ exclamación ${ }^{72^{\circ}}$. Sin duda la frecuencia de esta clase de combinaciones textuales, de poderosos efectos enfático-patéticos, sugiere obligatoriamente la asociación de estos textos con la práctica de la efectista concionatoria contemporánea.

La combinación bimembre de cláusulas discursizas lógico-ronectadas/ expresión enfática, nos es ya conocida desde los sonetos amorosos, donde estuvo muy bien representada, singularmente en un tipo de textos sintomáticos. También es estructura frecuentadísima en los textos religiosos, nada menos que trece ejemplos en una muestra de cien sonetos responden a esta estructura. Lo antedicho sobre la indudable influencia de los modos concionatorios como causa inmediata de la frecuente

"l'éase el texto indicado. sumeto 8. p. 31!):

¡()h corazon mais duro que diamanne!! ¿qué repugnancia es estat que te opprime? ¿No basta que con viva vol te anime apuel lince del alma pencerante:

¿Qué importancia el apetito repugnamte contra el objeto que su luz le imprime. si la efíaz. ravon, que le reprime. no deja (que del sucko se levallte:

Ánimos, pues, que la vitorial es tura. no pierdas tiempx), si el perdiklo sobra. antes que mi proxess se concluya.

Pon los desers. pues te importa, en obra. no des lugar que la oxasion se huya. que en el último fin tan mal se cobrat.

\footnotetext{
72 Los sonetos encuadrados en este grupx) son: 2, "l'asos de mi primera edad. que

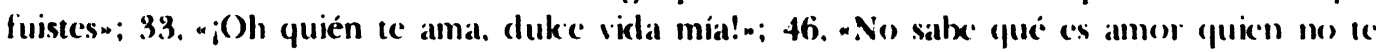

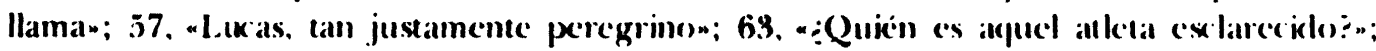
85. "Duke señor, mis vanos pensamicntosn; 91, "Si quise, si adoré, iqué crmor lerrible!". (omo texto tipixo de este grupx) propxonemos el soncto 46. p. 3.3!):
}

No sabe qui es amor quien no ke ama. celestial hermosura, espesso bello; tu cabeya es de oro. y tu cabello) como el cogollos de la palma emranada.

Tu bxa como lirio que derrama licor al alba; de marfil tu cuello; tu mano el (orno y en su palma el sello) que el alma por disfray jaxintos llama.

¡Ay Dios!, jen qué pensć cuando, dejando) tanta belleza y las mortales viendo, perdi lo que pudiera estar goviando:

Mas si del tiempo) que perdí me ofendo. tal prisa me daré, que un hora amando venza los años que pasé fingiendo. 
reiteración de este tipo de estructuras, se descubre nítidamente en muchos de estos textos, verdaderos pasos de sermón con toda la carga de efectismo que conllevan. Véase, por ejemplo, la ponderación y deixis patéticas que concurren en el soneto 16, verdadera quintaesencia de un sermón barroco ${ }^{73}$. Un rasgo típico de gran interés en nuestro caso es la multiplicación de términos de la apelación que concurren en cada uno de estos textos; no sólo el aludido soneto 16 -apelaciones a Cristocorazón propio-, sino en otros varios de esta misma clase se registra análogo fenómeno. Por ejemplo, en el soneto 20, lengua/Dios, y en el 25, Cruz/Dios. En los demás casos la apelación es regular, singular por tanto ${ }^{74}$. Una modalidad muy próxima a la anterior es la que constituyen dos sonetos, el 54 y 84 , en los que la oposición al énfasis de los tercetos no se hace mediante discurso expositivo rico en conectores lógicos, sino mediante una cláusula narrativa.

La peculiaridad de estas macroestructuras argumentativas en Lope de Vega, y la evidente asociación a las mismas de principios estilísticoretóricos muy activos en la concionatoria de la época, se concretan además en la aparición en las Rimas sacras de una modalidad especial de macroestructura textual argumentativa, que no se había presentado, en ningún caso, en las Rimas de 1609 . Se trata de otra variedad fundamentalmente efectista y enfática, que procura un cierto modo de comienzo «ex abrupto», una suerte de «in medias res» de la coherencia enfática. La estructura es justamente la inversa de la que acabamos de describir; es decir, ahora la expresión enfática -exclamativa-retórico-interrogativa, con

${ }^{73}$ Cotéjese el texto aludido, soneto 16, p. 323:

Muere la vida, $y$ vivo yo sin vida, ofendiendo la vida de mi muerte. Sangre divina de las venas vierte, y mi diamante su dureza olvida.

Está la majestad de Dios tendida en una dura cruz, y yo de suerte que soy de sus dolores el más fuerte. y de su cuerpo la mayor herida.

¡Oh duro corazón de mármol frío!, ¿tiene tu Dios abierto el lado izquierdo, y no te vuelves un copioso río?

Morir por él será divino acuerdo; mas eres tú mi vida, Cristo mío, y como no la tengo, no la pierdo.

${ }^{74}$ Otros sonetos de este tipo, además de los mencionados en el texto: 4, «Si desde que nací, cuanto he pasado»; 21, «Tardar en convertirse, error notable»; 26, «Detén el curso a la veloz carrera»; 31, "Yo me muero de amor, que no sabía»; 47, "Si de la sombra de tu cuerpo santo»; 49, «En la señal de la paz que Dios hacía», y 58, «Si de piel asperísima ceñido». 
vocativos muy marcados y frecuentemente con todos los recursos operando simultáneamente - se anticipa a los cuartetos, quedando en los tercetos remansada la reflexión mediante fórmulas de discurso lógico trabado por conectores, o más raramente en cláusulas expositivas o narrativas de relativa independencia ${ }^{75}$. La intención retórico-efectista que sirve esta estructura nos parece evidente, y se conecta con toda una teoría de la predicación contemporánea, que creemos fundamenta la especial naturalèa de la lírica religiosa de Lope. Por lo demás conviene no olvidar, no sólo la originalidad y novedad de este tipo argumentativo, en el inventario de recursos estructurales sintáctico-textuales de Lope; sino, además, su no bajo índice de frecuencia, ya que son doce los textos de esta clase que figuran en el conjunto de las Rimas sacras, anunciando ya su positivo auge en la evolución posterior de Lope.

El sistema expresivo era particularmente fecundo y efectivo, con su inicio apresuradamente enfático, para significar los sentimientos de desazón religiosa que atormentaban al atribulado pecador Lope de Vega. Son sonetos de contenido sintomático, como el 5, «Qué ceguedad me trujo a tantos daños?», o el 12, "Si es el instante fin de los presentes»; e incluso de apelación vehemente del poeta a su propia persona desdoblada, el contrito frente al pecador, como el 72, «Oh engaño de los hombres vida breve». Síntoma compatible también con la apelación divina, como el 11, «¿En qué bárbara tierra me guardara?». Sirve también esta estructura a la expresión de efectos de sorpresa o de deixis muy plásticas, como en el caso del soneto 71 a San Roque: "Jaque de aquí con este santo Roque», y el del 52, al sepulcro de Cristo: «¿Qué armas son éstas? ¿Qué guión colgado?». Por lo general, el apresuramiento enfático se frena en el límite entre cuartetos y tercetos, así

7s Véase como soneto de este tipo el 59, p. 346:

(aaiga el hermoso como cedro y palma.

caiga el Querub, que fue su nacimiento con el aurora, y tuvo atrevimiento donde todos poder se humilli y calma.

Caiga, perdiendo la vitoria y palma. del monte del excelso) Testamento, y suba la humildad al mismo asiento, a vos. Francisco humilde, en (uerpo y alma.

Si al (ruxifijo. Serafïn divino. volvéis los rayos, sois espejo claro tan parecido, cuando en vos se mira,

que ya sois serafìn, y al justo vino, subiendo a ser del que cayó reparo. ángel no es muxho, mas llagado admira. 
ocurre en la totalidad de los sonetos antes citados y en algunos otros ${ }^{76}$. Pero se dan también casos en que las expresiones enfáticas traspasan dicha línea, salpicando los cuartetos de estos textos llenos de efectismo ${ }^{\text {"7. }}$.

\section{Tipología macrosintáctica tópica y evolución personal artistica en Lope}

\subsection{Consideraciones generales. El «corpus» textual tardio}

4.0.1. Entre las Rimas sacras aparecidas en 1614, y las Rimas de Tomé de Burguillos publicadas por Lope un año antes de su muerte, en 1634, discurre un largo período de la vida del Fénix. Las experiencias acumuladas por cualquier artista en esos veinte años de madurez son, con toda seguridad, definitivas. Pero en el caso de una personalidad como la de Lope, nadie duda que tales experiencias podrían superar la posibilidad de evolución de cualquier humano normal. En efecto, aun cuando no es objeto directo de este trabajo tematizar las cuestiones siempre muy relevantes sobre la relación texto-sociedad, o texto-biografía, conviene recordar cómo la línea general de arrepentimiento, de sublimación platónica del amor carnal de las Rimas de 1609 -compatible en el caso de Lope con caídas diarias y aun con caídas habituales-, que Lope tematiza en la Circe, desemboca en las burlas de Burguillos; semánticamente, por tanto, la evolución es total. Apresurémonos a afirmar que en nuestra opinión -y creemos que es una verdad evidente para cualquiera-, la satira de Burguillos no es tanto una burla senil de los ardores amorosos juveniles, cuanto una parodia de la escritura tópica amorosa.

La evolución en Lope es completa. En este sentido, conviene -incluso en un tema como el nuestro actual- no separar los textos de parodia amorosa de aquellos otros en que se tematiza burlescamente, en general, los hábitos de la tradición tópica en literatura. Pese a todo, conviene indicar aquí, desde el comienzo, cómo -a nuestro análisis al menos- no se ofrece claramente una evolución correlativa en el dominio de la construcción textual. Con la fuerte evolución semánticotemática que permite hablar de total renovación en ciertos aspectos, no se corresponde, pues, una evolución macrosintáctica paralela. Así pues, creemos que queda suficientemente probado que los hábitos de argumen-

\footnotetext{
${ }^{76}$ Nos referimos también al 17, „jOh, bien hayan las lágrimas lloradas”, y 27, „¿Cómo puede, Señor, justificarse?».

${ }^{7}$ Casos, por ejemplo, como los sonetos 87 y 89.
} 
tación del discurso en el dominio clásico de los textos-soneto eran muy limitados, incluso mucho más limitados que los tópicos temáticosemánticos. Téngase presente al respecto que la aceptación apriorística de una cuadrícula argumentativa restringida como la del soneto, con catorce unidades versales organizadas en dos cláusulas mayores, bipartidas a su vez en otras dos cláusulas -así como, incluso, las posibles determinaciones de la organización fónica de acentos y rimas que aquí no hemos tenido en cuenta-, presentan obviamente una base de restricción textual, de cuya comprensión sería ingenuo no tomar nota. Con todo, creemos, no obstante, que las posibilidades combinatorias para la macrosintaxis de este tipo fijado de textos pueden ser mucho mayores, y a buen seguro hubieran sido utilizadas, si la fórmula final anhelada por el artista clásico, en este caso Lope de Vega, hubiera problematizado precisamente la renovación o la variación del discurso textual amoroso también en su dimensión artística macrosintáctica. Pero, a nuestro juicio, lo que se pretendía era precisamente participar de la tendencia opuesta; es decir, lo que se manifestaba poderosamente era la propensión a repetir las fórmulas argumentativas preestablecidas en la tradición. Incluso pensamos, «a posteriori», que este restringido núcleo de estructuras sintácticas de argumentación macrotextual era operado por los escritores, de modo casi automático, por no decir inconsciente, en nuestro caso por Lope de Vega. Al menos en términos relativos, respecto de la temática macrosemántica, es incontrovertiblemente así.

Los autores españoles sintieron quizá regularmente la tentación y la necesidad de alterar en alguna medida el universo temático topificado del amor cortés en la tradición italiana petrarquista, a la medida de las propias exigencias de sus respectivas vivencias artísticas y personales. Tal propensión -cuya verificación no hemos abordado aún, pero que como hipótesis resulta muy verosímilmente aceptable - se manifestó sin duda entre otras muchas maneras bajo ciertas fórmulas de innovación temática absoluta o relativamente novedosas en el esquema topificado temático que hemos establecido en principio en L. T. T. L. Por su parte, Lope peculiarizó casi todos los tópicos temáticos tradicionales de los que participó, abandonó muchas estructuras temáticas al uso, inauguró alguna, y sobre todo rompió frecuentemente los límites tolerados por el sistema tópico-semántico, tematizando en términos pragmático-sintácticơs irreprochables dentro de la tradición tópica situaciones vitales amorosas absolutamente anormales dentro del esquema temático usual, reconstruido por nosotros en L. T. T. L. a partir de la fórmula inicial intransgredible.

4.0.2. Sin embargo, todo lo anterior no significa que no sean cla- 
ramente perceptibles en Lope ciertas corrientes de evolución en los usos argumentativos macrotextuales, que se apuntan ya claramente en los sonetos de la Circe y que cobran estatuto definitivo en el conjunto de las Rimas de Tomé de Burguillos. Tales tendencias, que precisaremos inmediatamente, se ofrecen, sin embargo, como corriente selectiva dentro del marco general de clases de argumentación textual macrosintáctica. Es decir, lo que se percibe claramente en Lope de Vega es la progresiva tendencia, patente en los textos de este último período, a abandonar ciertos modelos textuales macrosintácticos - por ejemplo y singularmente las estructuras marcadas enfáticas: imperativo, vocativo, interrogación y exclamación enfática-, y a frecuentar otros - por ejemplo y sobre todo las estructuras isodistributivas múltiples tanto en narración como en exposición apelativa y/o sintomática- Pero, insistimos, dicho desplazamiento no supone, èn ningún caso, un modo de ruptura o innovación respecto del orden argumentativo tradicional y tópico. Las estructuras de isodistribución múltiple, crecientemente frecuentadas se presentaban ya, aunque en grado mucho más restringido, en las primeras colecciones de textos líricos de Lope de Vega, cuyo estudio hemos realizado en este trabajo.

Claro está que también estos desplazamientos internos en el sistema de argumentación macrosintáctica de Lope de Vega son evidentemente significativos. Su funcionamiento dentro de un determinado cuadro tópico, que evidenciamos en este estudio, no quiere decir que queden absolutamente vacios de sentido en la explicación y en la evolución artística de Lope. En concreto, las dos tendencias contrapuestas antes indicadas en el dominio de la argumentación textual macrosintáctica se compaginan perfectamente con la tendencia temática progresivamente perceptible en Lope a la ruptura del énfasis tópico en la temática tradicional. Cuanto más marcada se hace la afirmación de las vivencias autobiográficas de Lope de Vega en estos textos, llegando sobre todo a la esperpentización paródica de los amores del licenciado Burguillos y la lavandera Juana, tanto más se evidencia paralela ruptura con sus hábitos constructivos iniciales; el abandono de las marcas enfáticas por parte de Lope de Vega en la macrosintaxis de sus textos, y en consecuencia la creciente implantación de un orden de argumentación discursiva progresivamente ajustado en sus cláusulas sintáctico-rítmicas -l isodistributivo múltiple- constituye a nuestro juicio un caso evidente de correlato en los dos órdenes macrotextuales temático y argumentativo.

Una última conclusión podemos extraer de estos hechos, cuya verificación abordamos en los epígrafes siguientes. $Y$ es que el conocido principio del estructuralismo genético de que son las estructuras formales de los textos los mejores testimonios del mensaje social $\longrightarrow$ perso- 
nal- del texto, resulta aquí evidentemente corroborado. Sin embargo, su validez debe ser profundivada precisamente obviando la indudable carga de ambigüedad con que, en el entendimiento preciso de la estructura formal, ha operado tradicionalmente la poética-lingüistica y la critica literaria que han problematizado en torno) al estructuralismo genético. Evidentemente, la profundización que lleva a cabo en nuestros dias la Lingüistica textual, singularmente como «ideación. y formaliaación del texto en los trabajos de János S. Petöfi, nos permite hoy deslindar con casi total nitidez entre argumentación/tema, como categorías macrotextuales; sintaxis/semántica microtextuales; y sintaxis/semántica sentenciales. Tales categorías, unidas a las específicamente estilístico-sentenciales operadas tradicionalmente en la estilística y en la poćtica estructuralista. ofrecen un banco de pruebas evidentemente óptimo a la mcjor comprensión y delimitación del bloxpue formal en los textos literarios. Fenómenos como la correlación textual temático-argumentativa. constituyen evidentes muestras de la necesidad de tal profundización y de los límites internos que implica en la estructura, demasiado comprehensiva y allalógica si se menciona por sí misma, de la forma literaria.

\subsection{Síntomas de la evolución correlativa en los sonetos de La Cirre (1624)}

4.1.1. De los cuarenta y cinco sonetos que constituyen el conjunto de La Circe, sólo un pequeño grupo presenta ya categorías tan extremadamente frecuentadas en las primeras obras como los textos en anticlistribución y los narrativos. Respecto a la antidistribución, pueden ser considerados como tales el soneto conmemorativo *A la entrada del Príncipe de Gales» y el satírico-literario "Claudio, si no inventé las bigoteras», que aparecen respectivamente en los lugares 36 y 39 de la colección de sonetos ${ }^{78}$. Ambos son tipos aún bastante puros que resuelven sólo en el último terceto la sentencia básica. En el soneto al Príncipe de Gales: «Arco divino... / hijo del gran Neptuno... / tú... / dilata el celeste velo...*. En el 39: «Claudio, si... / si... / si... / ¿̨qué murmuran de mí los censuristas?...», aunque la índole sentencial de las transformacio-

\footnotetext{
7" Como no se ofrece en La Circe numeración de los sonctos, se la adjuclikaremos nosotros según el orden de la edición. Nos referiremos sicmpre a dicho número en lo) sucesivo, con la indicación complementaria del título " primer verso para su mejor kacalización. La incidencia de las propias circunstancias biográlixas de lope, amorosas c incluso profesionales - su pretensión de un puesto oficial de cronista- en el desarrolk) de la constante platónica que domina la Cirre, fue destacada ya porr M. Muñoz Cortés en su edición de esta obra (París, 1961).
} 
nes de extensión del elemento de la frase núcleo ponderada, así como el engarce necesario de dicha frase con otras conectadas en el último terceto contribuyen a presentar estos sonetos, más que como muestra genuina de antidistribución unisentencial, como casos de plurisentencialidad $^{79}$. Lentamente, como veremos, el tipo plurisentencial se hará aún menos frecuente en las Rimas de Burguillos, adelantándose la resolución de la frase núcleo al primer tercero y quedando, por tanto, su estructura bastante próxima a la de tipos simples de isodistribución. Esquema que anticipa ya en La Circe el soneto 8: "Este vínculo notable de las cosas".

Respecto a los sonetos narrativos, junto a textos de estructura dual dramatizada perfecta, como el soneto 6: "Dejaba a un sauce el instrumento asido" ${ }^{80}$, el 15: "Pasaba el claro Eveno a Deyanira", comienzan a perfilarse interesantes variaciones que cristalizarán en ejemplos de nueva distribución en Burguillos, como es el caso del soneto 27, dedicado a la ingratitud, "Vidas y arpadas nuezas a labores". Tal esquema de

${ }^{79}$ Como muestra véase el soneto 36, p. 1307 :

Arco divino, que, en color, celosa Iris del cielos de la gran Bretaña. después de tanta tempestad, España te mira en breve esfera luminosa:

hijo del gran Neptuno y de la hermosa reina del mar en su cerviz montaña. donde la selva Calidonia baña eterna de cristal corona undosa.

tú que en cielo portátil partes solo luz con el sol, en paz, amor y celo triforme resplandece en nuestro polo:

dilata esmaltes al celeste velo, que en darte su lugar promete Apolos que nuestra luna ilustrará tu cielo.

"o Véase, como ejemplo, el texto aludido, soneto 6, p. 1289:

Dejaba a un sauce el instrumento asido Amarilis, con justo sentimiento de un cabrero mordaz, que de su acento con vana presunción habló atrevido.

Viole è las ramas el pastor Leonido, y dijo, conociendo el instrumento, al dueño ausente con piadoso intento, no menos lastimado que ofendido:

"No por villanos rústicos nos prives de tu sonora voz, por más que intente la pena que de bárbaros recibes.

- Canta y alaba al Cielo eternamente pues eres de sus coros, mientras vives, con voz divina humana pretendiente.* 
construcción se ofrece muy próximo a un tipo de estructura macrosintáctica de argumentación especializada en textos de contenido moral, que consideraremos representativos del tipo temático sintácticosemántico de las fábulas, presente en la Circe en textos como el soneto 22, de isodistribución múltiple, "Subió atrevido miserable enano" "1. La estructura básica, presentación-narrativalexpresión en estilo directomoraleja, la cumplen también sonetos como el 26: «Concediendo el gran Júpiter las fiestas». con estructura isodistributiva dual. Dentro del tipo de narración dual dramatizada que estamos considerando, el soneto 9 , sobre el tema de Orfeo "Los tigres ablandé, pasé los ríos», nos ofrece una muestra de limpia distorsión del modelo, sin desaparición del mismo, ya que consiste en inversión del orden habitual: presentación narrativa/acción dramatizada con expresión en estilo directo. Los textos 30, "Tuvo Platón por firme fundamento". y 41, "A Juan de Vander Hamen Valderrama, pintor", son casos normales de narración no dramatizada.

4.1.2. Como ya se ha indicado anteriormente, la frecuencia de los textos de isodistribución múltiple aumenta en las últimas colecciones líricas de Lope sensiblemente. Una de las causas es que el porcentaje de textos morales que se registra en estos últimos libros crece sustancialmente respecto del número de los amorosos. Supone en principio esta clase argumentativa un tipo de contenido semántico pausado, caracterizado por la rotundidad y el orden elocutivo, coincidiendo por tanto en todo con las necesidades de la argumentación moral, ampliamente representada en la muestra de la Circe. En ocasiones se suceden las cuatro cláusulas como expresión de recomendaciones o instancias morales, expresadas mediante suaves formas imperativas, como los sonetos 16 , "Albano, a nadie ofendas en tu vida", y 38, "No te fatigues, Celio,

"I Véase, como ejemplo, el texto aludido, soneto 32. p. 1298:

Subió, atrevido, miscrable enano en una hormiga. de su cuerpo Atlante. gloriosa de llevar su semejante: tal puede en proporción el arte humano.

Sin espuela en el pie, rienda en la mano. caminaba tan bravo y arrogante. como pudiera el César más triunfante en el aplauso del laurel romano.

(corrió la hormiga y dis) con él en tierra. y entonces dijo: "Finvidia. ¿qué te ríes? De una suerte caímos yo y Faetontew.

Lidio, camina en paz. no me des guerra, que es grande diferencia, aunque porfies, caer de hormiga y de celeste monte. 
porque creas». Manifestándose, en otros casos de esta misma estructura, las instancias menos evidentemente al desaparecer el contenido moral, como el 35, conmemorativo, "A la máscara en que salió su Majestad», o el 40, “ $O$ Oh qué envidia me da Fernando el hombre».

Sin embargo, este tipo múltiple, tan frecuentado por Lope en sus últimas obras, presenta por lo regular indudables líneas de cohesión interclausular no marcadas. Quizá el rasgo más visible de esta disposición organizativa lo evidencia el énfasis creciente que recorre las estructuras del texto, hasta crear una evidente relevancia interna de las cláusulas textuales, manifiesta en la aparición del climax. Numerosos son los textos clasificables dentro de este orden que encontramos de la Circe, como anticipo de lo que se verificará ampliamente en las Rimas de Tomé de Burguillos. El esquema textual no es ciertamente nuevo. Lo hemos visto siempre representado en las obras de Lope, desde las Rimas, de 1609, y también, aunque muy escasamente, en las Rimas sacras (1619). El pequeño conjunto de sonetos de La Filomena de 1621 ofrece ya un síntoma del cambio estilístico en este ámbito; de los siete sonetos que se recogen en el texto, tres son plenamente identificables bajo esta estructura textual. Así es el soneto final que lleva a su vez el significado título "Castitas res est", y que puede considerarse como representativo de la estructura típica que conocemos de las Rimas, de clímax creciente con énfasis exclamativo marcado en el terceto final ${ }^{\mathbf{8 2}}$. Múltiples con clímax igualmente son otros dos sonetos morales o de tema literario de La Filomena, el que lleva el título "Nihil gloriosum, nisi totum", donde el clímax no viene representado, como hasta aquí, por una marca explícita enfática, sino por el juego de síntesis del terceto final en el esquema textual del soneto, y el dedicado a Juan de Peña, en defensa de Apolo", en el que el clímax es marcado, suavemente, tanto por la interrogación

*2 (ompruébese lo dicho en el soneto aludido, p. 913:

La calidad elementar resiste

mi amor, que a la virtud celeste aspira.

y en las mentes angélicas se mira,

donde la idea del calor consiste.

No ya como elemento de fuego viste al alma, cuyo vuelo al sol admira, que de inferiores mundos se retira, adonde el querubín ardiendo asiste.

No puede elementar fuego abrasarme; la virtud celestial, que vivifica, envidia el verme a la suprema alzarme.

Que donde el fuego angélico me aplica, ¿cómo podrá mortal poder tocarme? Que eterno y fin contradición implica. 
retórica final como por el efecto de tránsito textual de la exposición fabulística narrativa a la aplicación a caso concreto del último terceto.

La importancia de la clase textual macrosintáctica que estamos (o)mentando, nos autoriza a demorarnos en alguna medida para considerar algunas de las diferentes soluciones al climax que of recen los sonetos de La Circe. Por lo regular, en los textos de estas últimas obras de lope, el clímax no es nunca explícitamente marcado, como en los primeros, desde el punto de vista enfático-exclamativo. Ciñéndonos exclusivamente al caso de los sonetos con contenido amoroso de la obra, vemos cómo el soneto 1, "Amor con tanto.honesto pensamiento", representa el fenómeno mediante el paso de la exposición a la apelación directat; a través de un curioso juego pronominal, muy frecuentado en los textos de Lope de Vega. Según tal procedimiento, el tránsito entre la exposición sobre la dama o el confidente, en tercera persona, y la apelación. en segunda, se realiza sin ninguna marca explícita. Idéntico paso de exposición a apelación, pero quizá con tránsito marcado, justifícaría la catalogación en este grupo del soneto 7, "De la beldad divina incomprehensible». Muy similar a los casos anteriores es el del soneto 4 . "Canta Amarilis, y su voz levanta", sólo que aquí no se produce el paso anterior, sino el desplazamiento de la exposición narración-sbjetiva a la aplicación interpretativa en el terceto final. El juego de las deixis intratextuales sintáctico-semánticas desplaza, pues, a los rasgos explícitos enfáticos que determinaban la clase en los más tempranos textos de lope. Tal es positivamente el caso del soneto amoroso 10: "¿Qué Scita fiera, qué Cimera...*, en el que en todo caso se podría hablar de un clímax descendente, si nos atuviéramos a tales rasgos explícitos de efusión enfática, pues se trata de la transición de un conjunto exclamativo roto en el terceto final por la explicación expositiva. Soluciones del clímax más o menos análogas a las anteriores se registran en otros textos de contenido no amoroso de la Circe, que clasificamos bajo este mismo epígrafe $^{83}$.

4.1.3. Una clase sintáctico-argumentativa, como la que venimos designando de isodistribución dual sin marcas, no difiere realmente en gran medida de la de isodistribución múltiple que acabamos de examinar; la presencia de alguna base de solidaridad relevante entre los dos grupos clausulares del texto constituye una base de diferencia, que no siempre señala nítidamente el límite central del soneto entre cuartetos y tercetos.

${ }^{* 3}$ Relación de los sonetos aludidos, de iscodistribución múltiple-clímax: 14, "Habla Tebandro y saca de la fuente»; 20, "Yo dije siempre y lo diré y lo digo»; 21, "Cuéntame, Lidia, que la reina Helenaw; 34, en que se conmemora un lance cinegético del rey. "Opuesto al español, como al Tebano». 
Pese a todo, lo realmente cierto es que este esquema macroconstructivo, en especial el que hemos venido denominando como clase de distribución en agrupaciones intratextuales, comienza a adquirir también un singular relieve y frecuencia en las obras del periodo final de Lope. Por lo general, la estructura base que se mantiene invariablemente es la de la distribución del texto en torno a dos ejes o a dos "roles», según los casos, casi siempre distribuidos respectivamente entre cuartetos y tercetos. Por ejemplo, el soneto 2 de la Circe, "Como es el sol la causa conficiente", en el que se produce la presentación de los efectos de amor centrados en la dama a través de apelación con tú en los cuartetos, frente a la of recida de los correspondientes efectos en el poeta a través de los tercetos. Estructura que se cumple análogamente en los sonetos 3, con la distribución verdad general/tú-yo; 18, verdad general/ caso concreto; 33, caso de Eneas/aplicación en apelación a la dama, y 25, idéntico al anterior con el término de Orfeo.

Lo que en realidad traduce la macroestructura argumentativa anterior es la estructura de un símil, por lo que la estructura resulta particularmente adecuada en los casos de textos de contenido moral, en los que la aplicación en los tercetos funciona como moraleja, frente a la admonición universal expuesta en los cuartetos. De esta clase son numerosos los sonetos de la Circe. Como por ejemplo el 24, de estructura contrapuesta expositiva-término comparación/exclamativa-aplicación moral ${ }^{84}$; o bien, el 23, "Yo he visto en tierra y mar casos extraños», donde se produce la contraposición entre la enumeración totalizadora de los cuartetos, «Yo he visto"/frente a la concreción moral en los tercetos "Yo no he visto». Incluso en algún caso la estructura de símil es explícita, como en el soneto 32, "De la abrasada eclíptica que ignora", con estructura: narración de Faetón/así yo-así Faetón y yo. También el caso de la conversión

\footnotetext{
"Véase como ejemplo el aludido soneto 24, p. 1299:

Vive en las flores del rosado Oriente un ave sola al mundo, a quien decoro guarda hasta el mismo sol, el pico de oro, los ojos de un safiro transparente;

con punta de rubí, ciñe su frente de azules plumas un turbante moro, sin nácar, plata, y púrpura no hay poro que no produzga pluma diferente.

Salve, fénix hermosa, a quien consagro cuantas mirras Sabá, y inciensos. corta. y en cuanto al Ganges y Eufrates pasean.

Este honor de su patria, este milagro, Licinio, no eres tú, pues ¿qué te importa, si no lo puedes ser, que otros lo sean?
} 
moral puede manifestarse prioritariamente mediante las mismas formas expresivas: expositiva-caso general/directa apelativa-aplicación moral, como en el soneto 13, "De letras grandes el ajeno escrito".

Dentro de este grupo, los textos que hemos llamado de isodistribución dual en paralelo son más raros. En realidad los límites entre ambas subclases nunca se nos han antojado demasiado sólidos, y sólo en una primera aproximación general como ésta hemos optado por marcar las diferencias, especialmente porque en las obras tempranas de Lope el número de textos de ambas subclases era suficientemente elevado para tratar de descomponer la clase general. Pero en el caso de La Circe lo cierto es que no se justificaria en absoluto la distinción. Sólo un soneto, el 31, «Fabio, yo creo que eres más valiente», arroja el testimonio de un paralelismo explícito, pero imperfecto, de estructura a (yo creo)/b // a (yo creo)/c (pero no creo). Caso al que respondería, aproximadamente, el soneto de La Filomena, dedicado *A la muerte de don Jerónimo de Ayanza, el de las grandes fuerzas" (p. 907), a través de la estructura invocación-muerte-exposición/invocación muerte-exposición conclusiva.

4.1.4. La clase de sonetos de isodistribución dual con marcas explícitas aparece en el conjunto de La Circe notablemente reducido respecto a lo que había sido el caso de las primeras obras. Más que el conjunto de los sonetos de argumentación lógica con conectores explícitos, representados aquí a través de cuatro composiciones ${ }^{85}$, la clave de la disminución la ofrece, sin duda, el cada vez menos frecuentado modelo de los sonetos con marcas enfáticas, que, como recordaremos, constituían el recurso central del Lope de las Rimas, aún muy apegado a la tradición tópica, tanto en temática como en construcción textual.

En tal sentido, La Circe inicia ya una pauta que desembocará en las Rimas de Tomé de Burgillos, atestiguándose, por tanto, la tesis insistida por nosotros en estas páginas de que antes que una autobiografía amorosa, antes que una parodia temática de la realidad del amor cortés, las pretensiones de Lope de Vega no excedían en dicha obra su propia condición y oficio de escritor, al tematizar precisamente la parodia de la escritura amorosa, mediante el consciente distanciamiento de las estructuras tópicas. Y ello no sólo en lo que se refiere a las evidencias semántico-temáticas, sino hasta a las sin duda menos conscientes es-

\footnotetext{
" Remitimos al lector a la constatación de las marcas constitutivas de la clase, descritas ya minuciosamente en los correspondientes apartados de los capítulos anteriores. Los textos de La Circe que consideramos incluibles en este grupo son: 5, «Cuando con puntas de marfil labradom; 11, «La parte doce de los peces de orom; 12, «Si vas a conocer un gran poeta»; 28, dedicado a Vicenzo Carducho, pintor ilustre, que comienza «Si Atenas tus pinceles conccieran.
} 
tructuras macroargumentativas, e incluso - aunque a ello no extendemos aún nuestra búsqueda- a los estilemas sintagmáticos.

Sólo son cuatro los ejemplos de isodistribución con marcas enfáticas que hemos encontrado entre los cuarenta sonetos de la Circe. Y quizá lo definitivamente probatorio dentro de nuestra hipótesis es que en ningún caso se trata de textos con temática amorosa. Por lo demás, las marcas enfáticas en todos ellos no se presentan con la naturalidad expresiva de los textos correspondientes de las Rimas. Así sucede en el soneto 17 , "Silvio, para qué mirar las ruinas?", con la estructura vocativo/imperativo (no mires), o el 19, donde la fórmula imperativa de los tercetos está, incluso, diluida en expresiones negativo-discursivas "no es bien que vivos como muertos trates". Aún más expresiva es la disolución enfática en el soneto 29, "Flora, aunque viva por el mundo muerta", donde el vocativo inicial se presenta absolutamente asumido dentro del tono admonitivomoral expositivo de los cuartetos. Incluso en algún caso, como el del soneto 37, "A un cadalso", hemos considerado elemento de énfasis las típicas deixis anafóricas tan frecuentadas en este tipo de temática moral: "Estos que presumió mármoles parios... Aquí sujeto ya de dos contrarios". Por lo demás, el rasgo de disolución del énfasis en fórmulas bastante próximas a la estructura dialogístico-conectiva se apuntaba ya en los sonetos de esta clase registrados en La Filomena ${ }^{86}$.

4.2. El último estadio de la evolución. Macroargumentación textual en los sonetos de las Rimas de Tomé de Burguillos

4.2.1. Las tendencias generales que se han marcado en La Circe, culminan, como se ha dicho reiteradamente, en el Burguillos. Parece como si Lope de Vega hubiera querido poner en esta obra el broche irónico definitivo a su revisión crítica de la tópica tradicional literaria, sobre todo en el dominio de la lírica amorosa. En tal sentido, hemos dicho ya reiteradamente que las Rimas de Burguillos son mucho más todavía que una burla desordenada de los tópicos de una tradición de cuya crisis vital acaba por persuadirse Lope; antes bien, el gran valor sintomático de esta obra radica precisamente, según sospechas razonablemente fundadas, en que, al constituirse como parodia sistemática de una tópica que contaba a su vez con el recorrido a su véz tópico de una "via amoris», evidencia hoy los pasos o estaciones de dicha andadura. Con ello, por cierto, se descubriría que la sistematización tópica de Lope

\footnotetext{
"6éanse los sonetos aludidos: p. 907, «A una tabla de Susana, en cuya figura se hizo) retrato a una dama»; p. 909, dedicado a Juan de la Piña, «Piña el Tiempo veloz, porque devora», y el de p. 910 con el títuk) "Multum legedum, sed non multa».
} 
no diverge básicamente de la que nosotros habiamos deducido en nuestro esquema «a posteriori en L. T. T. L., actualmente simplificado.

Comenzando por los casos de narración con estructura múltiple dramatizada, se registran algunas muestras en sonetos satírico-burlescos, como el 28 con el título de "Cortando la pluma hablan los dos" ${ }^{87}$, el 46 , "Consuela a Tamayo de que todos le maldigan sin culpa», y el 63, *Perdonaron a un regidor sentenciado a degollar, y la guarda, por las albricias, empeñaba la mula». Cuatro textos representan la clase de los narrativos múltiples no dramatizados en la colección. Se trata de los sonetos de contenido amoroso burlesco, 8, "Alude a la saeta de Filipo, padre de Alejandro, que le sacó de los ojos Cristóbolo, excelente médico», y 124: "Intentó el poeta ausentarse para olvidar, y no le aprovechó el remedio, con que parece que habla de veras". Del mismo tipo de estructura argumentativa son los sonetos 29, "Juicio astronómico del día», y el 107. "Escribe a un amigo el suceso de una jornada*. La peculiaridad de estos sonetos, que marcan el progresivo adensamiento, particularmente sensible en su etapa final, de las estructuras macroargumentativas en Lope dentro del estilo que podríamos denominar de los textos de «relación de hechos» ${ }^{88}$, se corresponde claramente con una tendencia mucho más amplia.

Buena prueba de ello podría ser la aparición dentro de los textos narrativos múltiples no dramatizados de la modalidad de climax, que en las obras anteriores registrábamos sólo en sonetos de tipo expositivo. Nada menos que ocho composiciones de esta clase hemos tenido ocasión de censar en el Burguillos. La fórmula presenta un claro compromiso para salvar el progresivo debilitamiento de la tensión conceptuosa pro-

"7 El número de orden que daré de los sonetos de la colección del Burguillos se refiere al que se sigue de la edición de Lope, que no lo incluye explícitamente. En cualquier (aso, se indicará siempre en cada cita el título o el primer verso.

"nu Véase al efecto) el último de los sonetos mencionados. soneto 107, p. 1397:

(laudio, después del rey y los tapices.

de tanto grande y forastero incauto. no tiene la jornada, a ver el auto. que te pueda escribir que solenixes.

Fue todo cortesanas meretrices de las que pinta en sus comedias Plauto; anduve casto, porque ya soy (auto) en ayudarlas a comer perdices.

Ya los ventores, con el pico al norte. andaban por las damas circunstantes: que al recibir las cartas se da el porte.

Partióse el Rey. llevóse los amantes. quedó el lugar en breve olor de Corte. como aposento en que estuvieron guantes. 
pia del soneto en estos textos de Lope, donde prevalece más bien el tono de insistencia que el de tensión. Algunas veces el clímax lo crea el paso de la narración en símil a la aplicación al propio caso de la amada Juanilla, como el sonețo 13, *Lo que hiciera Paris si viera a Juana»; o bien, el caso general del tiempo, como el 80, «Encarece el poeta el amor conyugal deste tiempo" ${ }^{89}$; en otros, por el contrario, marca el clímax la presencia de alguna exclamación en forma enfática ${ }^{90}$. Resoluciones idénticas del clímax a las que se descubren en los tres sonetos de contenido burlesco no amoroso de la colección de las Rimas, alguno de los cuales resulta altamente significativo, por cuanto ofrece posible explicación al hecho del progresivo adensamiento de sonetos con esta estructura. Así es el caso del soneto 71 , donde se tematiza precisamente la transferencia al soneto de estructuras líricas macroargumentativas del tipo de estructuras sucesivo-progresivas, bien ajenas a la índole expresiva propia del soneto ${ }^{91}$.

"Vy V́ase como muestra el texto aludido, soneto 80, p. 1382:

Fugitiva Euridice entre la amena hierba de un valle, por la nieve herida del blanco pie, de un áspid escondida. pisándola clavel, cayó azucena.

Lloróla Orfeo, y a la eterna pena bajó animoso, y con la voz teñida en lágrimas, pidió su media vida: así la lira dukemente suena.

La gracia entonces, con tremendo labio. Plutón concede al conyugal deseo del marido, más músico que sabio.

En fïn, sacó su esposa del Leteo; pero en aqueste, tiempo, Hermano Fabio, ¿quién te parece a ti que fuera Orfeo?

${ }^{40}$ Caso de los siguientes sonetos: 75. «Da la razón el poeta de que la boca de Juana fuese rosa»; 90, „A una señora manteniendo un torneo con otras damas», y 100, «Burla vengada".

91 Véase el soneto aludido: „Egloga, sin imitación de Teócrito, Pomponio, Nemesiano, Boxacio, ni (ialfurnion, soneto 71, p. 1377:

Al pie del jaspe de un feroz peñasco. pelado por la fuerza del estío. dosel de un verde campo, tan sombrio, que contra Febo) le sirvió de casco;

Damón con su rabel, y al lado el frasco. para cantar mejor el desafío. y Tirsi. claro honor de nuestro río, con un violín de cedro de Damasco,

jüez. Eliso, que de un verde pobx), a falta de laurel, premio tejía.

(éfiro hizo de los ecos robu; 
Fn abierto contraste con lo que sucediera en obras anteriores -especialmente, por ejemplo, en las Rimas sacras- los sonetos narrativos dramatizados de estructura dual se presentan en proporción, si no irrelevante, sí ciertamente mucho más escasa. Por lo demás, en la colección del Burguillos ha desaparecido ya definitivamente el tipo habitual de esta estructura que se daba en obras anteriores; a saber con la presentación de la situación en los cuartetos y el parlamento de expresión directo en los tercetos. Sólo, un caso, el soneto 110, "Que sienten más los ricos la muerte que los pobres", responde, y no estrictamente, a tal estructura. La fórmula que vemos surgir aquí es la del diálogo entre personajes, ocupando los tercetos; como dice el propio Lope en el soneto 120 , "Conjura un culto y hablan los dos de medio soneto abajo". Burguillos discute con un portero del Parnaso en el soneto 5, "Cuenta el poeta la estimación que se hace en este tiempo de los laureles poéticos", o se mueve animado coloquio entre una atrevida pulga y el poeta en el chispeante soneto 97, "La pulga, falsamente atribuida a Lope". No faltando tampoco el soneto completo en voz directa del personaje, que ya hemos visto en obras anteriores, como el 39, "Desgarro de una panza en día de toros, habla el rocín". Otros sonetos, en fin, pese a ofrecer en principio la clara cesura dual de la isodistribución narrativa, retrasan al último terceto, o incluso a los últimos versos del mismo la expresión del diálogo narrativo-dramático ${ }^{92}$.

4.2.2. La clara ruptura con las fórmulas antaño preferidas de la isodistribución dual en el último Lope, que ya anuncian los sonetos narrativos reseñados, se acrecienta en los numerosísimos casos de sonetos con isodistribución múltiple de modalidad expositiva. Podemos decir que la mayoría de las composiciones del Burguillos participan de esta estructura, en abierta oposición a las Rimas, humanas y divinas; pero consolidando, sin embargo, la tendencia que se anunciaba ya en La Filomena. Evidentemente la sustitución del esquema macrosintáctico que vemos operarse en este caso, viene determinada por una clara voluntad estilística en Lope de luchar y romper la estructura clásica dual-conceptuosa del soneto. La vía era comprometida y difícil, y en verdad que Lope no

\footnotetext{
mas cuando) Tirsi comenzar queria.

ladró Melapo, y dijo Antandro: “iAl kbbo!»; y el cantos se quedó para otro día.
}

Otros textos del mismo tipo son: 143, "Que unos se mueren para que otros vivan". ! 154. "Reprehenden ks filósofios antiguos".

"2 Tal es el caso de los sonetos: 64, «A una dama cónica vencida de otra"; 79, "Al haño de dos nintas aloxues», y 146, «Describe el poeta su Juana en forma de sirena, sin valerse de la fábula de Ulises".. 
acertó siempre precisamente con esta tentativa de ruptura. Pero su voluntad de distanciarse de la tradición tópica en todos sus aspectos, que informa y organiza las Rimas de Burguillos, encuentra también un claro exponente mediante este trámite. Entre los sonetos no estrictamente pertenecientes a la burla amorosa, ocho corresponden a este tipo puro: el 23 dedicado al jurisconsulto don Juan de Valdés, los sonetos en serie 31 y 32 sobre el lance del obsequio de una bigotera por una dama a un galán lampiño, el 137, "Señor Lope: este mundo todo es temas»; el 147, "Responde a un poeta que le afeaba escribir con claridad, siendo como es la más excelente parte del que escribe", o el 139, de tema similar al precedente, "Reprehende el poeta los que hablan enflautado". La organización de estos textos oscila entre los de insistencia paralelística, distribuidos en las cuatro unidades estróficas, tales como el 35 dedicado a don García de Salcedo Coronel, con cuatro apelaciones enfáticas, o el 156 a don Francisco de Quevedo con sucesión de cuatro elogios: dándose también otros modelos de organización relativamente proyectados hacia la solución en clímax conclusivo, como el 36, «A la muerte del rey de Suecia", que presenta la peculiaridad bastante frecuentada de una aplicación conclusiva introducida por conector que causal en el último terceto.

En el conjunto de los sonetos amorosos con esta misma estructura sintáctica macroargumentativa de exposición múltiple se registran numerosos casos, en los que Lope busca y consigue el reiterado efecto de repetición paralela. Ejemplos muy claros son el del soneto 3, "Dedicatoria de la lira con que piensa celebrar su bellezaw, con la contraposición yo/tú en cada estrofa; el 43, "A una dama que se llamaba Paz", con la reiteración del nombre en todas las cláusulas métricas; el 96, “Enójase con Amor con mucha cortesía», en el que se suceden cuatro expresiones enfáticas; o paralelamente casos como el 91, "A una dama roma y fría", donde la insistencia cuádruple se monta sobre otros tantos insultos. Otros numerosos casos de esta índole los ofrecemos en nota ${ }^{93}$.

También como prolongación de la vía trazada en la Circe abundan sobremanera en las Rimas de Burguillos los sonetos expositivos de isodistribución múltiple en climax. El clímax impone, como hemos dicho, una forma atenuada de recuperación de la construcción efectista-

${ }^{43.3}$ Se trata de los siguientes sonetos: 4, «Disculpa la humildad del estilo con la diversión de alguna pena»; 15. "A un peine, que no sabfa el preta si era de boj o de marfilm; 20. "Envidia a un sastre que tomabal la medida de un vestido de una daman; 26. «A un palillo que tenía una dama en la brxa": 27. "Quedóle más que decir y prosigue en la misma materia"; 95. "A una dama tuerta"; 152, "Sentimientos de ausencia, a imitación de Garcilasom. 
conceptuosa del soneto en su estructura originaria, gravemente viciada a través de la fórmula reiterativa de isodistribución clausal métricosintáctica. Por eso, en el conjunto de textos de esta clase, quizá el elemento que juega un papel más decisivo en la fisonomía macroestructural de la argumentación sea precisamente el terceto final y la fórmula sintáctico-semántica operada en él para la consecución del clímax. Para empezar, señalemos que la autoconciencia del recurso en Lope es más que evidente, como lo testimonia incluso, con frecuencia, la tematización explícita en el título de algún soneto, tal es el caso del 126 titulado «Efectos de Amor, porque comienza humilde y acaba apasionado»; apasionamiento que, corroborado con marcas explícitas de énfasis: admirativo-exclamativo e interrogativo-enfático, constituye el tipo más directo y evidente de clímax que se registra en un buen número de textos de esta clase, amorosos y burlescos de tema general ${ }^{94}$.

Por lo común, la resolución del clímax se realiza mediante alguna forma de distorsión irónica sorprendente, como en el soneto 10, “Describe un monte sin qué ni para qué», donde tras la minuciosa descripción del lugar, bajo las marcas del paisaje tópico, marco del acontecimiento amoroso, concluye:

Y en este monte y líquida laguna
para decir verdad como hombre honrado,
jamás me sucedió cosa ninguna.

El recurso lo repetirá numerosas veces, casi siempre para producir el efecto de desmontaje tópico, como en el caso del soneto 18, del tipo del que en L. T. T. L. hemos denominado de anatomía del amor. Tras de la pormenorizada descripción del comportamiento de los «espirtus», concluye:

Mira, Juana, qué amor; mira qué engaño

pues hablo en natural filosofia

a quien me escucha jahonando paños.

\footnotetext{
" He aquí la mención de algunos casos: de la burla amorosa-cortés, 12, «Satisfacción de cekos"; 86. «Desdén de Juana y quejas del posta*; 125, «Había un duende en una casa y amaneció preñada una dencellaw. y 128, “Casóse un galán con su dama y después andaba celosom. En sonetos de otro tipo esta fórmula de clímax se hace presente: 14, "A una dama que, llamando a su puerta, le dijo desde la ventana: Dios le provean; 73, «Enfádase con las Musas porque intentaban escribir un poema"; 88, "Al corto premio de un amigo suyo que le merecían; 93, « Responde el poeta a un elogio que se hizo en Roma a su muerte fingida*. y 103. "Que desfavorece la patria los hijos propios con el ejemplo del excelente Camoes».
} 
Fórmula de introducir la realidad vital como contraste que constituye la base temática de toda la colección, y que se adapta muy ajustadamente a este tipo de macroestructura argumentativa. Añádase, como ejemplo de este tipo, el soneto 106 sobre los heroicos antiguos y las necesidades del tiempo ${ }^{95}$. Salidas irónicas de diferente tipo, todas con función marcadamente antitópica, se registran en el soneto 108, «A una dama que comía ceniza y sal», o en el 42, "A un zapato muy grande y desaseado de una dama».

- Resoluciones del clímax de. naturaleza muy ingeniosa se realizan también en diferentes textos. Como en el 94, «Desmayóse una dama de ver un ratón y habla con él el poeta»; aquí el clímax lo introduce la transferencia del tono irónico-burlesco a una salida de fino galanteo. Procedimiento análogo, pero sin tanta finura de requiebro, se introduce en el soneto 76, "Cánsase el poeta de la dilación de su esperanza». Modelo de clímax por gradación positiva que se registra también en casos de sonetos no burlescos, como el 14, donde la advertencia sobre el tono serio correspondiente al argumento va tematizada por Lope en el propio título: «Cuando heredó su Majestad estos reinos, intentó escribir de veras». La fórmula general, en el fondo, de todos estos casos es la contradicción, el retruécano intelectual, subrayado a veces por términos de conexión sintáctica con mas adversativo, como en el soneto .161, «Discúlpase el poeta del estilo humilde». Modelos, en fin, de construcción en clímax con resolución irónico-deceptiva son el soneto 61 «A un secreto muy secreto», o el 54, "Rasgos y borrajos de la pluma», en el que se produce el distanciamiento metaescritural que Lope tematizo tan

9s Soneto 106, p. 1396:

Penélope dichosa, no disputo si fuiste casta o no, porque tenias muy gentiles capones, que comias mientras faltaba tu marido astuto.

Las tocas bajas y el funesto luto, deja la falta de comer dos días; dura necesidad que, si porfias, será traidora Porcia al mismo Bruto.

Las mujeres son todas principales; si alguna su valor y ser desprecia, necesidad la obliga a casos tales.

No estaba pobre la feroz Lucrecia, que a darle don Tarquino dos mil reales, ella fuera más blanda y menos necia. 
frecuentemente, del que el tipo más conocido es el famoso soneto a Violante ${ }^{96}$.

4.2.3. Concorde con las tendencias geométricas macroargumentativas que vamos viendo articularse en el conjunto final de las obras de Lope de Vega, y que hemos sintetizado bajo el rasgo de la propensión a hacer desaparecer las marcas vigorosas de énfasis, o a la distribución a base de mạrcas de conectores muy perceptibles, hay que señalar también la enorme afluencia en el Burguillos del tipo macrosintáctico isodistributivo dual de estructura no marcada, aquel precisamente que se aproxima más a la isodistribución múltiple que acabamos de examinar. A no dudarlo, ambos tipos, la isodistribución múltiple narrativa y expositiva, y la isodistribución dual sin marcas representan más del ochenta por ciento de los sonetos de la colección. (ion ello, las propensiones estilísticas del último Lope y sus motivaciones artístico-personales, que hemos puesto reiteradamente de relieve en el (caso de la temática, quedan también corroboradas para el ámbito de la macroargumentación.

Aun insistiendo en la unidad general del tipo estructural que nos ocupa, incuestionable en último término, trataremos de mantener aquí también idéntica bipartición en subsectores, que hemos venido señalando en las obras anteriores. La causa de ello es más bien de indole gráfica y de economía de nuestras clasificaciones; tratando de ofrecer esquemas clasificatorios lo más poderosos posibles, para llegar a comprender grupos no excesivamente numerosos de textos en cada casilla argumentativa. En tal sentido, distinguiremos aquí todavia los sonetos de estructura dual con paralelismo interno, y los sonetos de estructura dual construidos en torno a la presencia de distintas modalidades organizativas, etiquetados como agrupaciones intratextuales.

Comenzando por los primeros, el tipo de paralelismo alternativo

\%6 Véase, como muestra, el soneto aludido, soneto 54, p. 1367:

Lazos de plata, y de esmeralda rizos,

con la hierba y el agua forma un chär(o), haciéndole moldura y verde marco lirios morados, blancoss y pajizoss.

Donde también los ánades castizos, pardos y azules, con la pompa en arcos, y palas de los pies, parecen barco en una selva, habitación de erizos.

Hace en el agua el céfiro inquieto) esponja de cristal la blanca espuma, como que está diciendo algún secretos.

En esta selva, en este charco en suma.. Pero, por Dios, que se acabó el soneto. Perdona, Fabio, que probe la pluma. 
$a / b / / a / b$ aparece bien representado. Así el soneto 14, «A la ira con que una noche le cerró la puerta», con la marca paralela de interrogación enfática en el elemento inicial de ambas ramas $a$ en nuestro esquema. La marca correspondiente en el soneto 40, «ncarece su amor para obligar a su dama que le premie», es la presencia de la apelación y el nombre concreto de Juana, los sonetos 101 y 102 -que forman una de las frecuentes parejas seriadas en Lope, declarada en los títulos respectivos: *A un gorrión a quien dába de comer una dama con la boca y el poeta, por honestidad llama jilguero», y la continuación: «Enojose con el pájaro porque le mordió la lenguam - también participan de esa distribución macroestructural mediante la alternación en las dos series, de cuartetos y tercetos, de las modalidades expresivas: énfasis-exposición/énfasisexposición, que corresponde también, en líneas generales, con la estructura del 18, "Prometieron favorecerle para cuando tuviera seso", y del 122, «A un coche de damas que iban al soto; y habla con el cochero, por no hablar con ellas». Mientras en el soneto 159 alternan las estructuras énfasis exclamativo-imperativo en ambas ramas, con el título significativo de «Exclamación del poeta por un hombre que siempre andaba diciendo que era muertox.

Como puede verse, algunos de los sonetos aludidos combinan marcas explícitas enfáticas, que bajo otros criterios hemos incluido' a veces en los grupos correspondientes; pero en aquellos casos la distribución de tales marcas era estrictamente dual, a uno y otro lado de la cesura clausular del soneto; no como aquí en series de distribución completa, a su vez duplicadas a ambos lados de la cesura. En algunos casos, sin émbargo, tal distribución se realiza no según el esquema $a / b / / a / b$, sino bajo otro distinto $a / b / / b / a$, con lo que se construye una estructura argumentativa en cierta medida antidistributiva, en el sentido de que la cesura clausal mayor del soneto funciona más como un gozne de partes idénticas, quedando las estrofas inicial y final en posición relativamente independiente. El esquema estructural a que nos referimos se generalizó bastante en la colección de sonetos de Burguillos, nada menos que nueve textos de esta indole descubrimos. Tres de ellos construyen un núcleo central de énfasis marcado, orlados por cláusulas periféricas expositivas; se trata del soneto 92, de burla literaria, «Dijole una dama que para qué escribía disparates», yotrosdos de sátira cortés: el 68, „describe unlindode este tiempo", y el 115, "Venció una dama cómica a otra que presumía de haberla vencido delante de sus 'Majestades*. El mismo esquema se repite en otros, pero con la distribución énfasisexposición, a la inversa, ocupando ahora la modalidad enfáticamente no marcada la posición central; por ejemplo, en el soneto 132, «A la muerte dé Timosca, perra 
de agua famosa, matóla la rueda de un molino". Cinco textos más constituyen un núcleo bastante significativo del desarrollo de este sistema de argumentación en Lope de Vega. El esquema en todos ellos se repite: apelación-vocativo/exposición o narración // exposición o narración/conclusión (conector adversativo) ${ }^{97}$.

4.2.4. Dentro del tipo de los sonetos de isodistribución dual sin marcas, el segundo de los subsectores indicado ya en el parágrafo precedente aparece tan cuantiosamente representado, que lo trataremos aquí en un apartado distinto. Se trata de los sonetos cuya estructura macroargumentativa viene explicitada a través de las modalidades que hemos venido denominando de agrupación intratextual. En el caso actual, por lo demás, el elevado número de textos que componen esta categoría puede darnos ocasión a perfilar mejor sus modalidades constitutivas básicas, respecto a la relativa indeterminación en la que, deliberadamente, la hemos ido dejando en el caso de las obras anteriormente analizadas, con un número sensiblemente inferior de textos representativos de esta clase.

La estructura básica, que organizó en cierto modo todas las subespecies, es la del símil. Una cláusula inicial de carácter universal referencial en los cuartetos, e inmediatamente su aplicación, llevada a término en los tercetos. En algunos textos, incluso, la estructuración del símil es tan marcadamente explícita que queda de manifiesto incluso con la presencia de conectores del tipo «tal es», "así», como gramemas introductivos de los tercetos. Tal es el caso del soneto $84^{\circ 8}$, o el 34 , «Los varios efectos de la lengua». En otras ocasiones, donde la conexión entre los términos

97 Se trata de los siguientes sonetos: 118. «A una dama que a todo respondia jzape!*; 119. "A una dama que criaba un cernicalon; 121. "Describe el río Manzanares en Julio»; 127, "A un amigo poeta, que iba fuera de buena gana», y 155, «Lamentóse Manzanares de tener tan grande puestew.

* Véase el texto mencionado, como ejemplo de esta estructura, soneto 84, p. 1384:

Cubre banda de pajaros difusa torre de iglesia o capitel de quinta; de negra vana las pizarras tinta máquina chilladora circunfusa.

Pero al primer rumor de voz intrusa. cuando más el pirámide se pinta, partiendo el aire, de volante cinta, con descompuesto error huye confusa.

Así cubren, Leonel, los detractores tu casa en rudo son, y los espanta la voz de los canoros ruiseñores.

Chillen en tanto, pues, que los levanta el rumor de las aguas y las fores para aplaudir: que Filomena canta. 
de la comparación no es directa ni explícita, ésta queda, sin embargo, de relieve a través de fórmulas implícitas, como la transición de la parte mitológica a la aplicación a Filis, en el soneto 50, cuyo título, por lo demás, 'explicita la condición del símil: «Prueba que Amor quiere que le correspondan con el ejemplo de la misma dama», en el soneto 129 , *Discúlpase cortésmente de no matarse ni le pasa por el pensamiento», y en el 131, «La que viene primera no es la mayor desgracia»; o bien la del lance término de comparación a la moraleja en el gracioso soneto 85, "Que no hay remedio contra los malos vecinos", o la aplicación de ejemplos naturales a la modesta hermosura de una dama en el 89 , «A una virtuosa pobre y hermosa que no quería ser rica». Más raro, aunque de estructura idéntica, es el caso de alteración del orden de elementos en la comparación, como sucede con el soneto 123, "A un maldiciente* en el que la apelación directa al personaje precede, en los cuartetos, a la fábula de intuición universalizada.

El caso de la transición del ejemplo al yo propio como término de la comparación no es sino un tipo especial dentro de la estructura general de símil, con la que tratamos de caracterizar esta macroestructura argumentativa. Varios son los textos que responden a esta fórmula; quizá modélico sea el 2, «Propone lo que ha de contar en fe de los méritos del sujeto» ${ }^{99}$. Pero casos también perfectamente correspondientes son el del soneto 135, «No tiene por hombres los que no aman, aunque no lo siente mucho», o el 22, «A las fugas de Juana en viendo al poeta, con la fábula de Dafne», que, además de lo explícito del propio título, se inicia con el significativo primer verso: «Como suele correr desnudo atleta». Otros casos equivalentes serían el soneto 38 , que incluye la comparación de un predicador famoso hijo de Madrid, Francisco de Quintana, con las demás lumbreras madrileñas de la sagrada cátedra, y el del 57, sobre el

99 Véase el texto aludido, soneto 2, p. 1338:

Celebró de Amarilis la hermosura Virgilio en su bucólica divina, Propercio de su Cintia y de Corina Ovidio en oro, en rosa, en nieve pura;

Catulo de su I.eabia la excultura a la inmortalidad pórfido inclina; Petrarca por el mundo, peregrina, constituye de Laura la figura;

yo, pues Amor me manda que presuma de la humilde prisión de tus cabelios, poeta montante, con ruda pluma,

Juana, celebraré tus ojos bellos: que vale más de tu jabon la espuma. que todas ellas, y que todos ellos. 
saco de Mantua, dirigiéndose a Virgilio y comparando los dos momentos; en este ejemplo el título, una vez más, es significativo de la estructura: «Al saco de Mantua por el ejércita del César, con el verso de la Egloga nona de Virgilio. Escribe en seso, porque habla con él».

Otro esquema de esta estructura, desconectado del mecanismo del símil, es el que contrapone en las dos partes del soneto las modalidades expresivas. Claro está que lo que tales cambios expresivos refuerzan, con frecuencia, no es sino la bipartición temático-estructural del texto, como en el representativo ejemplo del soneto 25, "A un avariento rico»; aquí el tono expositivo inicial sobre el avaro contrasta con la apelación enfática al heredero para que derroche los caudales recibidos. Estructura que, respecto del confidente, se reproduce en el 48, «A don Francisco López de Aguilar». El soneto burlesco fúnebre 49, «A la sepultura de Marramaquiz, gato famoso en lengua culta, que es en la que ellos se entienden* contrapone el tono deíctico-anafórico propio de estas composiciones: «Este, si bien sarcófago, no duro»... al imperativo catastrófico de los tercetos: «Ploren tu muerte Henares, Tajo, Tormes». Enfasis imperativo se opone a narración del caso en el soneto 59, «A la braveza de un toro que rompió la guardia tudesca». Siendo todavia muy numerosos los sonetos de este tipo, que por no causar innecesarias insistencias, remitimos a nota ${ }^{100}$.

En otros grupos de textos la distribución dual viene determinada de dos estadios actanciales, dos «roles» personales o, simplemente, dos etapas de una misma acción. Tal es el caso, por ejemplo, del soneto 77, donde se describe la desdeñosa respuesta que se ha de dar a los murmuradores en el ejemplo de la actitud de uun lebrel irlandés de hermoso talle» ${ }^{101}$. Textos englobables en este grupo serían el 99, «A una dama

\footnotetext{
100 Por ejemplo en el 69, «Desea el poeta que le piquen avispas», se pasa de la narración genérica a la apelación concreta a Juana; en el 73, la organización es inversa, tras de la apelación al confidente se sigue la aclaración expositiva del caso, su título «Que en este tiempo muchos saben griego sin haberlo estudiado.. En el 130, ¿Castiga amor un mal gusto con un mal ejemplon, combina narración y exposición conclusiva enfática; 133, “A una dama que en un balcón estaba cosiendo unos escarpines muy pequeños*, donde se sucede la exposición de la acción y su aplicación galante; 149, "Al retrato de una dama đespués de muerta", en el que se diacute, en sus dos partes, la acción del pintor y su oportunidad.

101 Para ejemplificación del tipo, véase la estructura de la acción global en dos momentos, soneto 77, p. 1380:
}

- Un lebrel irlandés de hermoso talle, bayo, entre negro, de la frente al anca, labrada en bronce y ante la carlanca, pasaba por la margen de una calle. 
que le preguntó qué tiempo corre", y el 51 , "Vuestra merced se puso a la ventana". Expresión de doble etapa de un proceso la podrían representar los sonetos de escritura, como el 45, «Madruga a escribir el poeta y toma por achaque el enfadarse del mundo para volverse a dormir»; o sobre todo el 9, otro de los sonetos de reflexión irónica metaescritural del tipo del soneto a Violante, o del 2 de esta misma colección de Burguillos, pero que, a diferencia de este último, de idostribución múltiple, como recordaremos, presenta la interrupción metaescritural en la cesura textual mayor argumentativa ${ }^{102}$. Por último, de distribución dual con este tipo de estructura macroargumentativa es el soneto 53 , de carpe diem «sui generis», organizado en torno a los dos procesos del tipo ponderación/degradación.

4.2.5. En el gran bloque de tipos textuales con un modo similar de macroargumentación, que, como vemos, asume la práctica totalidad de los sonetos existentes en la colección del Burguillos, junto a los ya señalados de isodistribución múltiple y dual sin marcas explícitas, añadiríamos nosotros el crecido número - si bien inferior a los anteriores- de textos de isodistribución dual con marcas explicitas no enfáticas. Es decir, textos discursivos de estructura silogístico-argumentativa bien apoyada y subrayada por conectores lógicos explícitos; pero en los que predomina la

Salió confuso ejército a ladralle,

chusma de gozques, negra, roja y blanca,

como de aldea furibunda arranca

para seguir al lobo en monte o valle.

$Y$ como escriben que la diosa trina, globo de plata en el celeste raso. los perros de los montes desatina.

este hidalgo lebrel, sin hacer caso, alzó la pierna, remojó la esquina. y por medio se fue su paso a paso.

102 Véase este interesante soneto 9, p. 1342:

Érase el mes de más hermosos días, y por quien más los campos entretienen, señora, cuando os vi, para que penen tantas necias de Amor filaterias.

Imposibles eran mis porfias, que como los favores se detienen, vos triunfaréis cruel, pues a ser vienen las glorias vuestras, y las penas mías.

No salió malo este versillo octavo, ninguna de las musas se alborote si antes del fin el sonetazo alabo.

Ya saco la sentencia del cogote; pero si, como pienso, no $k$ acabo, echarele después un estrambote. 
andadura expositiva distendida que vemos caracteriza la argumentación de los sonetos de la etapa final de Lope, frente a los encrespados efectismos tópico-enfáticos de las primeras obras, o incluso en clara ruptura con la naturaleza habitual conceptuoso-sorpresiva que lleva aparejado el texto del soneto. Precisamente un texto de esta misma clase tematiza irónicamente la razón del abandono por parte de Lope de toda esta suerte de efectistas inovaciones enfáticas. Se trata del curioso soneto 136, «Discúlpase con Lope de Vega por su estilo», uno de esos preciosos sonetos de desdoblamiento metaescritural del Lope transfigurado en Burguillos, que tanto abundan en estas Rimas burlescas de 1634, jocunda vía purgativa para la envarada escritura tópica tradicional. Copiamos el texto aludido:

Lope: yo quiero hablar con vos de veras, y escribiros en verso numcraso, que me dicen que estais de mi quejoso, porque doy en seguer musas rateras.

Agora imvocaré las verdaderas, arengue os sea (qu? sois escrupuloso), con tanta metafisica, enfadoso, y tantas categóricas quimeras.

Comienzo, pues: ¡Oh tis que en la risueria aurora imporimes la celeste llama, que la soberbia de Factón desperia...!

Mas, perdonadime Lope, que me llawa desgreviada una musa de estameria, celosa del tabi de vuestra fama.

No nos cabe duda, por tanto, que lo que produjo el cambio de modelos argumentativos, o por mejor decir, el desplazamiento de frecuencias observado en el uso de los mismos en estas obras finales, es la consciente y deliberada voluntad del autor de revisar irónicamente la temática tradicional. Un ejempló que lo atestigua es la inmediata recuperación de la estructura tópica argumentativa en aquellos sonetos del Burguillos en que desaparece, por alguna especial circunstancia, la condición irónica. Así sucede en el caso del ternísimo y delicioso soneto de galanteo del inefable Lope, rendido delicadamente a su devoción por el eterno femenino, ante el misterio renacido de la femineidad entrevista 
*al descuido* en su hija adolescente Antonia Clara ${ }^{103}$. Si la argumentación lógico-conectada era, como sabemos, la fórmula canónica para la estructura de galanteo, la vemos aquí puntualmente concitada por Lope, cuando no se cuestiona sobre la necesidad de renovación temática. Un nuevo dato a este argumento lo ofrecería, a su vez, el significativo soneto I38, el único de galanteo de todo el Burguillos que cumple con la exigencia sintáctico-argumentativa de este tipo. Pero, como consciente de su deslizamiento en el tópico con el que pretende romper, Lope se apresura a prevenirnos de sus razones en el largo título del sonetoi "Quebróse a una dama el espejo cuando iba a tocarse, y escribe de veras, -añade-porque no le riñan. Escribe -insiste-con mucho tiento".

Esta recuperación de la macroestructura argumentativa tópica cuando se produce la asunción del tema correspondiente, justifica el caso general de la distorsión temático-constructiva del Burguillos. Ni en un solo ejemplo se registra la asociación del galanteo a esta clase de estructura argumentativa en los siete textos de temática amorosoburlesca en que se producen macroestructuras de este tipo ${ }^{104}$. Incluso alguna vez se tematiza explícitamente el móvil de abandono del tema, a pesar de conservarse la estructura tópico-argumentativa, como en el soneto 148: "Justifícase el poeta de que no nacen flores cuando las damas pisan los campos - típica situación del galanteo tópico-, porque estima en más la verdad de Aristóteles que el respeto de Platón..

103 Véase el texto aludido de la colección del Burguillos, soneto 150, p. 1421:

Quien amanece al sol, quien al sol dora,

dejando, libre, discurrir el pelo

por el blanco marfil y debe al cielo

las rosas que la noche le colora,

parece (con las galas que atesora)

que a la naturaleza dio desvelo,

y que en las luces del celeste velo

buscó ella misma su primera aurora.

Si sois Amor, para robar despojos

en hábito de niña, hoy cesa; hoy para

cuanto de su rigor causaba enojos.

Que si fuérades vos, Antonia Clara,

la niña de las ninas de sus ojos,

rompiera el arco Amor: mirar bastara.

${ }^{104}$ Descrita ya suficientemente la fórmula estructural respecto a su incidencia en libros anteriores, nos limitaremos aquí, por brevedad, a la simple nómina de los textos que presentan esta estructura: 7, "No se atreve a pintar dama muy hermosa por no inentir, que es mucho para poetan; 11, «Túrbase el poeta al verse favorecido"; 67, "Quejasele una dama de un bofetón que le habla dado su galán"; 82, "Quejase de Venus el poeta, con un poco más de eso que suele»; 113, "Que amando no hay dificultad»; 144, "Si se han de tener celos:; 148, aJustificase el poeta de que no nacen flores cuando las damas pisan los campos, porque eatima en más la verdad de Aristóteles que el respeto de Platóni. 
En los textos de temática no amorosa, donde esta modalidad argumentativa se halla también profusamente representada, se evidencian asimismo con toda claridad los efectos de ajuste o adaptación de la temática a la macroestructura sintáctica. Por ejemplo en el sintomático 87, "Al nacimiento del Príncipe, nuestro señor», resulta evidente que el tono enfático que hubiera correspondido a la modalidad conmemorativa regia, se ve limado y sustituido por Lope con este modelo argumentativo dialogístico, en consideración de la desproporción del énfasis con la naturaleza de la criatura nacida; y recordemos de paso la despierta sensibilidad de Lope para la ternura infantil, que le arrancó en todos los géneros y ocasiones algunos de sus poemas más sinceros e inspirados. El tipo estructural sintáctico se ajustaba con toda propiedad a los temas discursivos, en los que Lope llegaría a alcanzar maestría única, dentro de una estructura argumentativa no particularmente distinguida por su brillantez y efectismo. Recordemos, si no, el tan difundido soneto 112 , "Que no es hombre el que no hace bien a nadie", que contiene el tantas veces repetido juego conceptual de Rubens y Marino ${ }^{105}$

4.2.3. - Pasemos ahora a examinar el contenido de las Rimas de Tomé áe Burguillos en lo que se refiere a tipos de estructuras marcadas por la presencia del énfasis. Advirtamos previamente, como ya hemos hecho de modo reiterado, que su número es muy sensiblemente inferior para esta obra que lo había sido en las primeras Rimas. $Y$ aún deberiamos añadir que la mayor parte de las composiciones que aquí consideramos, están

105 Véase el texto aludido, soneto 112, p. 1399:

Dos cosas despertaron mis antojos, extranjeras. no al alma, a los sentidos: Marino, gran pintor de los oídos, y Rubens, gran poeta de los ojos.

Marino, fénix ya de sus despojos, yace en Italia resistiendo olvidos; Rubens, los héroes del pincel vencidos, da gloria a Fla[n]des y a la envidia enojos.

Mas ni de aquél la pluma, o la destreza déste con el pincel pintar, pudieran un hombre que, pudiendo, a nadie ayuda.

Porque es tan desigual naturaleza. que cuando a retratalle se atrevieran, ser hombre o fiera, les pusiera en duda.

Otros textos de temática no cortés con este esquema sintáctico macroestructural son: 33 , «A la muerte del Marqués del Valle»; 37, «A la décima Musa, doña Bernarda Ferreira de la Cerda, señora portuguesa»; 60, "Trece son los tudescos que el horquillo»; 62, "A un licenciado que le dijo por favor que deseaba predicar a sus honras»; 142, «Pregúntale una dama qué era el áureo número», y 158, „Pregúntale un caballero si habría comedias por el principio de una que le enviabax. 
sólo relativamente jalonadas de marcas enfáticas. En la mayoría de los casos el énfasis, bajo formas por lo demás bastante atenuadas, es un componente que no se extiende sino a una de las partes del texto dualmente fragmentado, alternando por lo común con formas de tono discursivo, organizadas mediante la presencia de conectores explícitos. Se hace presente con ello la sensación de abandono de los mecanismos sintáctico-semánticos de tensión textual por parte de lope de Vega, precisamente en la vía de ganar en naturalidad expresiva, más próxima sin duda a su propio sentido de la expresividad cotidiana y coloquial; $y$ como firme oposición a la impostación artificialmente sentida de los moldes tópicos de la poesía culta tradicional, que, a lo largo de su propia vida, Lope fue quizá progresivamente identificando con el siempre aborrecido culteranismo.

Dentro de estos bloques de tipos macroestructurales de énfasis estilístico poderoso figura, sin duda, la clase de antidistribución, que en los capítulos anteriores, correspondientes a otras obras más tempranas de Lope, hemos tratado siempre antes -dentro del orden establecido en nuestro esquema orgánico de clasificación-; pero que en el caso de nuestro análisis del Burguillos preferimos agrupar en este punto con el resto de las estructuras estilísticamente forzadas, precisamente para dejar patente la sensación de contraste intencional, manifiesto en esta obra final de Lope, entre ambas clases de textos, radicalizadamente altẹnativos y siempre con desventaja de las formas más innaturales.

Formas estrictamente tales de antidistribución enfática no existen en el Burguillos. Si se recuerda la definición macroestructural de este tipo argumentativo que hicimos en capítulos anteriores $(2.1$ y ss.), resulta claro que a esta estructura macrosintáctica se le confía la expresión tópica de la vehemencia, de la recóndita sorpresa artificiosa. La evolución intencional estilistica de la lírica de Lope nos previene claramente frente al enrarecimiento de esta clase de soluciones. En puridad un solo caso, y no de los más limpios, existe en el Burguillos; se trata de la composición que expresa la más invariable necesidad vital, aun en el lope más anciano, la falta de dineros en los cultivadores de la poesía ${ }^{106}$.

106 Véase el ejemplo aludido, soneto 109, p. 1398:

la rueda de los orbes circunstantes pare el veloz primero movimiento; déjese penetrar el pensamiento; iguálese la arena a los diamantes.

Tengan entendimiento los amantes y falte a la pobreza entendimiento; no tenga fuerza el oro, y por el viento corran los africanos elefantes. 
En todos los demás casos, seis en total -con la excepción quizá del soneto 70, "A la muerte de Soto el de las grandes fuerzas"-, la antidistribución es marcadamente plurisentencial, y aun diríamos que se trata sólo de formas parcial y muy condicionadamente antidistributivas.

Una forma usual de resolverse la antidistribución en la mayoría de los casos es adelantar hasta el comienzo del primer terceto el cierre sentencial de la frase-eje. Por ejemplo en el soneto 66, «Díjole una dama que le enviase su retrato", donde la construcción se establece entre los versos 1 , «Si habéis visto al sofí sin caperuza», etc., y 9 , "ése soy yo»; en el soneto 83, "Dándole a una dama un abanillo que se le había caído", la construcción se establece también: 1-2, "Este que en el jardín de vuestra cara, / céfiro artificial, templó la rosa...»; 9-10, «pongo en mi frente y doy a vuestra pura / nieve...". Formas más atenuadas del tal adelantamiento, por cuanto la resolución sentencial se cumple en la totalidad del primer terceto, las ofrecen sonetos como el 17, «Pregónase el poeta, porque no se halla en sí mismo", o el 117, «Decía una dama que no hallaba a quién querer"; este último con la estructura: 1, "Entre tantas guedejas y copetes..."; 9-11, "entre tantos que van el pico al viento / que a los que ruegue por lindeza esperan, / ¿no halláis a quién querer? ¡Extraño cuento!». En todos estos casos de adelantamiento sentencial, la coda clausular resultante la constituye una fórmula de restricción adversativa, con mas o pero, o causal explicativa con que. Por último, en algún otro caso, como el soneto 111 , "La primera vez que vio la mar", aunque de construcción puramente antidistributiva con resolución frástica en el último verso, las expansiones frásticas precedentes son tan extensas y desarrolladas en sí mismas que se deteriora el efecto unisentencial, y hasta el antidistributivo, muy poderosamente.

4.2.7. Como ya hemos indicado, dentro de las macroestructuras de argumentación con marcas explícitas enfáticas, la construcción más generalizada en la colección de sonetos del Burguillos es, sin duda, la que combina el énfasis con la exposición discursivo-conectiva. Incluso, formularemos aquí una observación que, habiéndonos asaltado con frecuencia durante la ejecución de este trabajo, no hemos encontrado suficientemente justificado desarrollar hasta ahora; se trata de la posibilidad de: subclasificar internamente las colecciones de poemas de Lope, muchas

\footnotetext{
Blanco sea el cuervo y negros los jazmines, rompan ciervos del mar los vidrios tersos, y naden por la tierra los delfines;

no sufra la virtud casos adversos, den los señores, hagan bien los ruines, pues hay un hombre rico haciendo versos.
} 
de ellas, como las Rimas de 1609 , agrupadas y retocadas desde recopilaciones previas, y aun éstas producto, de la actividad creativa del poeta posiblemente durante decenios. Pero, como tal trabajo resulta incompatible con el amplio marco general que consideramos más urgente de pergenar para establecer una traza firme $y$ definitiva en la producción lírica de Lope, no lo hemos abordado nunca. Sin embargo, en la tesitura actual quizá sí conviniera señalar la distribución, no completamente casual, al comienzo de la colección de sonetos del Burguillos, de estas estructuras de apertura enfática, recuerdo de modos constructivos pasados, y objeto de progresivo abandono a lo largo de la colección. Imperativos, vocativos y exclamaciones forman entre los recursos enfáticos de estos sonetos, que en los tercetos construyen cláusula compleja poblada de conectores lógico-sintácticos ${ }^{107}$.

La distribución temática de esta estructura es mayoritariamente amoroso-cortés, quizá como reminiscencia del uso tópico de las construcciones con énfasis retórico en los textos de contenido tópicoamoroso, que Lope cultivó tan obviamente en las Rimas humanas ${ }^{10 x}$. No faltando asimismo los sonetos con esta estructura argumentativa dentro de otras clases temáticas, entre las que predominan, sin embargo, los

${ }^{107}$ Como ejemplo de esta estructura of recemos el soneto 52, "A un perro que mordia a quien tomaba la mano de su dama", soneto 52, p. 1366:

Paso, Amadis, que el reino del espanto tiene perro a la puerta, que no el cielo. porque las dos figuras de su velo si muerden con calor, no ladran tanto.

Dejad la mano, suspended el llanto, que más parece envidia que buen celo: de lo que no coméis, menos desvelo: o sois perro, Amadis. o sois encanto.

Con ser melindre, presumís de alano. o en vuestra lana Júpiter se muda, que si es de celos no ladráis en vano.

Si a mi fuego ponéis su nieve en duda, basta que tenga su desdén la mano: que sois muy chico para ser de ayuda.

10* Relación de sonetos que hemos tenido en cuenta con esta estructura: 1, „Desconfianza de sus versos"; 16, "Quejóse del poxo respeto que Juana tiene a sus letras, en que se ve la necedad de los que aman"; 21 , "Por las señas de este soneto consta quic se hizo por Navidad"; 30, "Hipérbole a los pies de una dama (que este preta debio de nacer en sábado)"; 41, "A una dama que salió revuelta una mañana»; 72, "Alaba el poeta ko más esencial de la hermosura sin ser parte de la armonía de las faccionesn; 151, "Celos del poeta porque vio a Juana columpiándose una tarde con otras doncellas", y 158, "Lloraba Juana por una camisa que le hurtaron en el río y quítase el poeta la suya por que no la riñesen en su casam. 
tonos no burlescos - sonetos encomiásticos, conmemorativos y epitáficos-, inclusiones excepcionales en el texto del Burguillos.

Del examen de este último grupo de textos queda reafirmada, por lo demás, la condición muy atenuada del elemento enfático, que raramente alcanza la generalización extensa de una interrogación enfática extendida a los cuartetos, como en el soneto 115, "A Luis Vélez de Guevara, del crédito que tienen los extranjeros"; o se reiterará en estructuras anafórico-apelativas de vocativo en el comienzo de los dos cuartetos, como se hace en el soneto 6, "Pésale de ser poeta y se le debe creer. Habla el Parnaso". Lo normal ahora son formas de suave invocación distendida, como la que se registra en el soneto 160 , "Al príncipe de Esquilache", y más frecuentemente una apelación inusitada en forma de vocativo suave, diluida inmediatamente en una larga digresión expositiva que ocupa casi siempre el segundo cuarteto. Fórmula esta que se registra, de manera idéntica, en varios textos, como el 104, «A los Raguallos de Bocalini, escritor de sátiras", o en otro soneto con el tema del mismo escritor, feroz enemigo de todo lo español, 141, «Dijo el Bocalino que un español que mató un italiano en desafío no traía camisa"; análogamente el 134, "A la muerte de un catedrático de escrituras. Escribe de veras». La relajaciọ́n de énfasis alcanza incluso, a nuestro juicio, a que determinadas estructuras argumentativo-temáticas, como la deíctico anafórica muy propia de sonetos fúnebres, se puedan adaptar sin violencia a esta misma clase general. Así propondríamos la inclusión en este grupo del soneto 47, "A la muerte de una dama, representante única", y del 58, «A don Gabriel del Corral, en la traducción de los versos latinos de nuestro santísimo padre Urbano octavo".

La inversión del tipo anterior, es decir, la combinación discursivoenfática, se registra también en algunas composiciones, como en el soneto 56, "A Bartolomé Leonardo", y en el 78, "Que al amor verdadero no le olvidan el tiempo ni la muerte". En cualquier caso, la pérdida de este modelo estructural respecto a los usos generalizados en obras anteriores resulta casi total; como lo es también la práctica inexistencia de un tipo muy próximo a éste - bastante frecuentado en las colecciones tempranas-, el mixto, representado sólo en el texto de Burguillos por el soneto 98, «Quéjase de que le aborrece Juana, hablando como astrólogo". Evidentemente el enrarecimiento de estas construcciones textuales hay que incluirlo en el caso general de decadencia de las formas macroargumentativas enfáticas, que vamos corroborando en todos los casos.

Finalmente, ni por la rotundidad del énfasis, ni menos aún por el número de sus representaciones puede parangonarse la situación del tipo enfático más marcado, con énfasis doble en cuartetos y tercetos, con 
su pujante presencia en las obras iniciales. La distribución en apelaciónvocativo-exclamación o apelación-vocativo-imperativo, apenas se hace relevante en estos textos de énfasis absolutamente diluido, a cuya corroboración en detalle remitimos al lector interesado en ello ${ }^{109}$.

5. Esquemas de construcción macrotextual en Lope de Vega y su posibilidad de generalización a la lírica del Siglo de Oro

\subsection{Generalidades}

La propuesta que encierra el enunciado de este capítulo es de la mayor importancia. Si los tipos macroargumentativos de Lope, bosquejados con su multiplicidad de incidencias en los capítulos anteriores, pudieran ser generalizados estrictamente al caso de otros escritores del Siglo de Oro español, resulta evidente que estaríamos en presencia de un sistema macrosintáctico tópico, constituido a su vez como agregación de tipos macroestructurales tópicos. Sin embargo, los límites a tal posibilidad son muy relativos. Obviamente, incluso a una simple lectura superficial se detectan diferencias evidentes entre la labor de todos nuestros grandes creadores clásicos, aun tratándose de una temática topificada, como lo es sin duda la amoroso-cortés, y de un tipo de estructura formal, a su vez doblemente tópico, como el del soneto. Así pues, en principio, podemos advertir que los tipos macroestructurales últimos, tal y como los recogemos en los cuadros clasificatorios de sonetos de Lope, no son total e inmediatamente clarificadores para la obra de otros poetas. Otra cosa puede afirmarse, no obstante, sobre los grandes principios de la organización macroestructural que hemos propuesto al comienzo de la parte sintáctica de este estudio. Por ejemplo, las estructuras enfáticas, bajo la forma vocativo/imperativo, tan frecuentes en el prime Lope, son raramente generalizables a Quevedo o a Góngora; sin embargo, deteniéndonos un escalón antes, y si hablamos tan sólo de macroestructura dual con marcas explícitas enfáticas - de naturaleza y distribución no precisadas- sí resultaría posible encuadrar bajo tal definición un buen número de sonetos de Quevedo, Góngora o Fernando de Herrera.

\footnotetext{
${ }^{109}$ Con esquema vocativo/exclamativo: 24 , «A la molestia de los pleitos»; 55, «A imitación del soneto Superbi colli»; 65, "A una dama que salió a un balcón cortándose las uñas»; 114, "Que libros sin dueño son tienda y no estudio». Con estructura vocativo/ imperativo: 81, «De la buena cosecha de poetas conforme al pronóstico de los almanaques»; 145, "Al cuidado de calzar justo una dama»; 153, "Aconseja a un amigo como cortesano viejon.
} 
La explicación indudable de tal fenómeno no es discrepante con los presupuestos generales que hemos sostenido en este y otros trabajos anteriores, sobre la condición esencialmente tópica $-y$ por tanto sistematizable por análisis- de la lírica clásica española, englobable en las enseñanzas y la práctica artística de la lírica en la tradición literaria de las lenguas románicas. Tanto en el aspecto de la sintaxis como en el de la semántica nuestras organizaciones tipológicas -es decir, nuestras descripciones tópicas- se han detenido siempre en el nivel de la macroestructura, o lo que es igual, en el de la construcción y la temática. Para nosotros es hasta tal límite donde la combinatoria tópica resulta posible de describir. Obviamente más allá, en el dominio de la combinatoria microcomponencial, el inventario de elementos a considerar es muchísimo más denso, si bien tampoco infinito. $Y$, por lo demás, operan más en este nivel del microcomponente las decisiones literarias individuales, es decir, lo que la Estilística tradicional ha definido más propiamente como "estilemas de autor». En tal sentido -y dentro de nuestro ejemplo anterior - la noción isodistribución/dual/con marcas explícitas/enfática es una descripción propiamente macroestructural argumentativa. Sin embargo, a medida que vayamos descendiendo y especializando la definición; por ejemplo, como antes, si describimos un tipo concreto de énfasis en Lope de Vega, como narrativo/imperativo, resulta evidente que nos vamos acercando a niveles microestructurales, en los que la generalización transindividual va siendo cada vez más difícil e inexacta.

5.0.1. Un tipo de verificación como ésta creo que puede contribuir muy poderosamente al urgente establecimiento riguroso y convincente del limite entre las estructuras macro y microcomponenciales del texto. La explicitación de tal problema en este artículo no la abordamos nunca directamente, salvo lo indicado en 0.2 , pero creemos haber aportado buena cantidad de materiales implícitos en el problema. No obstante, en las páginas sucesivas de este mismo capítulo deslizaremos abundantes consideraciones explícitas sobre el tema de los límites. Vista desde otro ángulo, la cuestión del límite, tal como viene planteada en este trabajo, creemos que puede aportar también decisivas aclaraciones a otro de los más graves problemas de la Poética tradicional y de la Poética lingüística actual: la cuestión de la distinción entre literariedad y poeticidad; al menos en el dominio estricto de la estructura formal artístico-literaria estamos persuadidos de ello.

No obstante, la propuesta anterior implica en el grado de pluralización de las terminologías actuales - que es en gran medida un problema de incultura clásica-, la necesidad de explicitar aquí previamente lo que queremos entender nosotros en este caso por literario y poético. Para 
hacerlo procuraremos mantenernos en los valores menos personales y más tradicionales. Lo más clarificador es considerar ambas acepciones dentro de una gradatoria progresiva de niveles de lengua, que establece la opósición primaria entre lengua literaria y no literaria, y distingue dentro de la primera entre literariedad y poeticidad de los mensajes lingüísticoartísticos, abriendo cada uno de los subsectores a una gradatoria de literariedad y de poeticidad de los distintos textos ${ }^{110}$. En tal sentido se suele considerar la literariedad como un hecho de decisión, mientras la poeticidad de un texto se considera vinculada a un hecho de fortuna, de acierto. La mayor parte de los elementos implicados en el problema estaban ya presentes en la capital discusión aristotélica de la Poética sobre si era el verso o la imitación lo decisivo para conferir condición poética -Aristóteles no problematizaba allí entre literario/poético- a un texto determinado. Al descartar el verso como determinante automático de la poeticidad, Aristóteles indicaba indirectamente que las obras históricas, bien escritas y aun escritas en verso, eran literarias, es decir no puros mensajes de lengua común, en los que no hubiera procedido la discusión; pero no poéticas. La poeticidad no era un valor, por tanto, de estructuras culturales explícitas inmediatamente asequibles y seguramente incorporables; por el contrario, al aludir al arte de la imitación, Aristóteles parece sugerir algún modo de maestría individual, no automática y regladamente alcanzable.

Si nosotros contemplamos la complejidad del problema anterior sólo desde nuestra óptica actual, puede que resulte un punto de vista nuevo absolutamente no desdeñable para la clarificac:ón del mismo, que se vincularía estrechamente con el debatido tópico de la virtualidad de la noción de macroestructura. La macroestructura define para la lírica clásica el limite de lo literario, mientras que la microestructura constituye el dominio en que se resuelve y produce especificamente la poeticidad. Aceptada la macroestructura de un soneto, temática y constructiva, como un hecho cultural establecido tópicamente por acuerdo, la decisión de hacer un soneto de «carpe diem», por ejemplo, no implica en principio condición alguna de

\footnotetext{
110 Obviamente, no nos ocuparemos aquí por extenso de resolver la cuestión en todas sus consecuencias, ni menos aún de hacernos eco de la inmensa bibliografia existente sobre el problema. Tratamos tan sólo de poner una cuestión, suficientemente conocida pero encrespada y revuelta, a la luz clarificadora de nuestras consideraciones actuales. El problema de la poeticidad como categoría artistica o como clase de estructura formallingúlatica, han ocupado explicitamente cientos de páginas de nuestros libros y artículos hasta ahora. Nosotros hemos elaborado una extensa sinopsis de nuestras propias ideas en

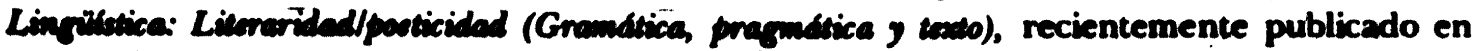
-1616. Anuario de Literatura general y comparada., II, 1980.
} 
acierto poético, sino sólo el conocimiento de un hecho pragmático. cultural-social, y de una corriente de opinión que reconoce que una macroestructura tópica de discurso, sintáctico-semántico, de tal naturaleza configura un tipo de objeto considerable en principio como literario. Será, sin embargo, en la ulterior realización de la macroestructura, a través de un conjunto de decisiones creativas individuales-constitutivas, de una bise cerrada de inventarios tópicos, de estilemas microtextuales, donde se alcanzarán o frustrarán los ralores de poeticidad de ese texto. Aún más claro se verá todo esto quizá, recordando las discusiones, contemporáneas a nuestros sonetos, sobre la aceptabilidad o no como productos literarios de determinados géneros -temas y estructuras formales lingüísticas-. Si en nuestro estudio temático en I. T. T. I. hemos demostrado cómo el conjunto de prejuicios tópico-temáticos, de admisión y exclusión; opera como un sistema cerrado de decisiones internamente socio-culturales, que se oponen incluso a la misma lógica natural y a la realidad histórica del amor en el mundo contemporáneo de los textos, resulta evidente que ése, entre otros muchos sistemas de ideas, constituye el marco de decisión pragmática de la literariedad. Pero los juicios de poeticidad, en cuanto establecimientos no de exclusioninclusión, sino de jerarquía valorativa, se nos ofrecen desde luego como algo no encerrable totalmente dentro de ningún marco cultural, lo suficientemente explícito al menos para hacer de ellos decisiones predecibles «a priori".

5.0.2. La cuestión anterior es tan compleja en sí misma, que renunciamos en este trabajo a apurar más nuestras propias razones. Baste $k$ dicho para quienes queden convencidos, y aplacen su decisión quienes discrepen, hasta que publiquemos una formulación más directa, exhaustiva y monográfica de este punto de vista. Lo que importa aclarar aquí es que nos ha quedado muy claro sin embargo, a través del presente estudio contrastado de la macroestructura argumentativa en poetas diferentes, la existencia de esa idea de límite. Digámoslo ahora de otro modo. Aunque, básicamente - y sobre todo recortando a lo esencial las distintas definiciones categoriales macroargumentativas-, se podrían encerrar, sin violencias demasiado grandes, dentro del reticulado de nuestros cuadros "ad hoc" para Lope la casi totalidad de sonetos de Garcilaso, de Herrera, de Góngora o de Quevedo, lo cierto es que el grado de definición de tales textos que se seguiria de semejantes decisiones de inclusión, no sería muy elevado; mucho menos, por supuesto, del que se sigue de las mismas decisiones en Lope.

La razón, sin duda, radica en que, en último término, tales esquemas macroargumentativos son sólo cuadros de referencia de la historia interna 
microsintáctica de cada texto; o bien, mirado al revés el problema, la macroestructura argumentativa es un precipitado en que se resuelve la microsintaxis del poema. Como dicha microsintaxis constituye, según hemos afirmado reiteradamente, el dominio de los estilemas de autor, vemos que, aunque el resultado macroestructural pueda ser idénticamente etiquetable entre autores distintos, como Lope o Góngora, el camino hasta dicha macroestructura es tan sustancialmente personal -sobre todo en el caso de los grandes creadores de que tratamos aquí-, que lo que prima en nuestra decisión de conjunto, como analistas o lectores, es el camino mismo sobre la meta o resultado.

De ahí que, a nuestro juicio, parece no sólo prudente sino imprescindible remontarse a bien entrado el dominio de la macroestructura para definir tipos argumentativos tópicos transindividuales en los textos de sonetos del Siglo de Oro, válidos a los distintos componentes de tal agrupación. Lo que justifica una distinción previa entre macroestructuras argumentativo-textuales tópicas, generalizables al caso de cualquier autor, y macroestructuras argumentativo-textuales individualizadas, como un grado de especificación de las primeras que se aproxima al límite macro/microcomponencial del texto. Lo cual no constituye, al menos desde nuestro punto de vista, ningún modo de objeción contra la realidad ni la virtualidad explicativa lingüística de la macroestructura; sino muy al contrario. Precisamente el grado de relativa autonomía de la diversidad microsentencial que el texto va ganando al escalar niveles de elevación macrosentencial cada vez más próximos a la génesis del tópico del discurso refuerza la imagen de la independencia y aun de la bipolaridad estructural existente entre los dominios del texto, pese a todas las dificultades, que subsisten, de determinar exactamente la zona de límites.

5.0.3. En nuestro actual intento de verificación del límite tópico macrotextual-argumentativo interindividual, hemos procedido del siguiente modo: hemos proyectado el esquema macroargumentativo obtenido en este trabajo de los quinientos textos de Lope de Vega analizados sobre el conjunto total, también de quinientos textos, de Garcilaso, Herrera, Góngora y Quevedo, ya examinados por nosotros temáticamente en L. T. T. L. La razón de escoger dicha muestra, aparte de la representatividad histórico-artística de sus autores, responde a nuestra voluntad de ir integrando progresivamente la muestra tipologizada dentro de una teoría general del texto-soneto en el Siglo de Oro. Por lo demás, no se olvide que la tipología macro-argumentativa establecida en este trabajo para Lope de Vega ha partido básicamente del análisis del "corpus» amoroso de las Rimas de 1609; existía, por ello, una homogeneidad temática entre los dos elementos básicos de la composición, que 
nos ha parecido garantía mínima a la hora de establecer comparaciones entre las dos muestras.

5.1. La tendencia dual discursiva y sintomática en la construcción textual de Garcilaso

5.1.1. De los treinta y cuatro sonetos amorosos de Garcilaso, la marca caracterizadora más regularmente establecida es, sin duda, la de la isodistribución dual. Si lo consideramos, por ejemplo, frente a la tendencia a la isodistribución múltiple preponderante en Quevedo y también, aunque en grado menor, en Fernando de Herrera, dicho rasgo define quizá la característica macrosintáctica básica de los textos de Garcilaso. Sólo tres sonetos rompen relativamente esta tendencia a la isodistribución en dos bloques: el 20, con una no muy marcada por cierto solidaridad en los tercetos; el 17 y el 36, ambos en notable énfasis de clímax.

La segunda característica sintáctico-macrocomponencial de los textos garcilasianos es complementaria de la primera: la preponderancia de sonetos no enfáticos. Sólo nueve textos, y entre ellos algunos de naturaleza no totalmente enfática ${ }^{\prime \prime \prime}$, responden a esta estructura ${ }^{112}$. Lo cual, si se añade el caso de los dos sonetos mixtos ${ }^{113}$ a medio camino, como se sabe, o más bien más próximos a los argumentativo-discursivos con marcas de conexión explícita-, presenta una gran mayoría de textos en los que la isodistribución dual viene definida mediante marcas discursivas de conexión lógico-sintáctica, o bien mediante marcas no explícitas de organización dual, generalmente deixis intratextuales. Dieciocho sonetos suman las dos clases mencionadas, con lo cual la caracterización proporcional del tipo

"I Evidentemente resulta bastante atenuado el tono enfático de los siguientes sonetos: discursivo-enfático-sintomático: 12, «Si para refrenar este deseo*; 31, „Dentro de mi alma fue de mi engendrado»; enfático-discursivo-sintomático: 26, „Echado está por tierra el fundamento». Seguimos, como en L. T. T. L. la edición de E. L. Rivers, Garcilaso de la Vega, Poesias castellanas completas, Madrid, Castalia, 1972.

${ }^{112}$ Los referidos sonetos enfáticos son: vocativo/imperativo, en apelación a la dama: 10, "Oh dukces prendas por mi mal halladas!, y 25, ";Oh hado secutivo en mis dolores!*; en apelación al confidente: 11, «Hermosas ninfas, que en el río metidas», y 28, «Boscán vengado estáis, con mengua míw; en apelación al poeta mismo: 30, «Sospechas que en mi triste fantasian; vocativo/exclamativo en apelación al Amor: 27, *Amor, amor, un hábito vestin.

1's Son los siguientes: mixto-apelativo a la dama: 2, "En fin a vuestras manos he venido"; mixto-apelativo al poeta mismo: 32, "Mi lengua va por do el dolor la guía”. 
en Garcilaso resulta evidente ${ }^{114}$. El conjunto de rasgos macroargumentativos que comentamos, contribuye a definir en no pequeña parte la impresión general estilística de serenidad (no enfática), fluidez (discursividad explícita) y orden (isodistribución dual) que la crítica ha señalado tradicionalmente en los sonetos garcilasianos, marcando así su orden de alta vecindad al "cursus" petrarquesco. El tono intimista y lírico que suele componer, con toda razón, el cuadro general de la definición estilística de Garcilaso puede derivarse, sin duda, de la positiva frecuencia de sonetos sintomáticos, unos trece en total, que en los diferentes tipos macrotextuales hemos ido mencionando 115 .

5.1.2. La comparación con Lope de Vega de la distribución del conjunto observado en los sonetos garcilasianos evidencia todavía más, en especial para el caso de los sonetos amorosos, el rasgo de efectismo dramático que hemos señalado como característica esencial de la lírica amorosa de Lope, vinculado a las dos palancas de tensión de la apelación frente al sintoma, y de las marcas enfáticas frente a las discursivo-conectivas. Garcilaso, Quevedo, y sobre todo Herrera, representan frente a Lope el mayor equilibrio del tono intimista-sintomático en el conjunto general de su producción lírica. Góngora, como veremos, ofrece una carencia de este rasgo análoga a Lope, de explicación posible muy diversa de la de éste. Pero con todos los demás poetas mencionados coincide Góngora, frente a Lope, en la evidente superioridad de los textos sin marcas enfáticas. Por último, se presenta también ya en Garcilaso, respondiendo, sin duda, a una práctica usual de sus inmediatos modelos italianos, la estructura de sonetos narrativos ${ }^{116}$, detectados con tanta frecuencia en Lope como rasgo de su preponderante personalidad de autor de teatro, asociando regularmente, incluso, el tipo de reproducción directa de discurso que hemos denominado dramatizado. Junto a Góngora, y frente a Quevedo y a Herrera, es Garcilaso, en esta clase de estructura narrativa, el principal modelo español antecedente de Lope de Vega.

114 Por brevedad, reproducimos sólo los números de estos conocidos sonetos: discursivo-apelativos a la dama, 18, 23, 38; al confidente, 35; sintomáticos, 1, 6, 15. Sin marcas explicitas, agrupaciones intratextuales, apelativos a la dama, 3, 4, 5, 9, 22; al confidente, 19, 33; sintomáticos, 7, 8 y 14. Tales agrupaciones reforzadas explícitamente en paralelismo constituyen el esquema del soneto también sintomático 34.

i's Copiamos aquí nuevamente, para cómoda verificación del lector, el número de los textos mencionados: $1,6,7,8,12,14,15,17,20,26,31,34$ y 36.

110 Se trata de los sonetos siguientes: múltiple, 13; múltiple dramatizado, 37; dual dramatizado, 29. 
5.2. Fernando de Herrera. Ejercicio formal de la tópica argumentativa italiana

5.2.1. Si hubiera que definir con un solo rasgo la imagen que of rece el esquema tipológico macroargumentativo de Fernando de Herrera, sin duda ésta sería la de su variado equilibrio. Como respondiendo al total de las posibilidades ofrecidas por la tradición poética del petrarquismo italiano, Herrera ensayó repetidamente toda la gama de estructuras macro-constructivas que aquél le of recía. Por el contrario, una tan densa muestra de textos - más de doscientos cincuenta- como la que hemos analizado en Fernando de Herrera, manifiesta el sistemático repudio de todas las formas y rasgos macro-argumentativos de énfasis efectista. En tal sentido, destacaríamos aquí la ausencia, o la sintomática minoría, de tres de las vías de argumentación efectista más frecuentadas en la lírica del Siglo de Oro, y que en el caso de Lope hemos visto densamente representadas: casi absoluta ausencia registran las estructuras de antidistribución, poco más las enfáticas puras ${ }^{117}$, y dentro de los modos expresivos, también ausencia de la modalidad que representa quizá el caso de mayor impostación enfática, la apelación del poeta a sí mismo ${ }^{118}$.

Respecto a los textos antidistributivos, resuita evidente que, como en la modalidad enfática, se trata no sólo de una representación numéricamente muy reducida sino incluso, en sí misma, constituida por las formas menos puras de antidistribución. Por supuesto, todos los textos registrados de esta clase no podrían ser clasificados sino como formas plurisentenciales de antidistribución; pero es que, con mucha frecuencia, la resolución de la sentencia estructural básica se ve adelantada ya al primer verso del primer terceto ${ }^{119}$, quedando el segundo terceto en posición de adversación plurisentencial. En otros casos, similarmente anticipados, el contenido de los cuartetos consiste en dos vocativos ${ }^{120}$, y en otros, como el 324, el primer cuarteto constituye una estructura plurisentencial independiente de la antidistribución.

Aparte de su relativa infrecuencia, los sonetos de marcas enfáticas en Herrera, frente a los de Lope de Vega, se caracterizan, sin duda, por la

11 Los casos a que nos hemos referido incluyen marcas de énfasis muy escasamente afirmadas. Remitimos siempre para el caso de Herrera a la consulta de sus textos según el número general de la composición en la edición de J. M. Blecua, de las Obras poéticas, Madrid, Anejos del B. R. A. E., 1975. Vocativo/imperativo, apelativos a la dama, 196, 209; al confidente, 208, 289; al poeta, 213, 315. Sólo un soneto vocativo/exclamativo, en apelación a la dama: 148 .

118 Se trata de las composiciones: $151,164,213,251,315,344$.

119 Es el caso de los sonetos: 38, 51, 92 y 227.

120 Es el caso de los textos: 171 y 296. 
estructura sumamente irregular y variada de la distribución del énfasis. Junto a los anteriormente mencionados en nota, que responden más o menos inmediatamente a estructuras de distribución enfática similares a las estudiadas en Lope, la mayoría de los casos presentan distribución distinta, como, por ejemplo, la que establece la siguiente organización: Vocativo/Imperativo // Imperativo/expansión discursiva, a la que corresponden, entre otros, los sonetos 209, 266, 315, 380 y 400; existiendo, como se ha indicado, un número muy elevado de combinaciones distintas del énfasis ${ }^{121}$. Por lo demás, el caso más frecuente es el de la distribución estrictamente dual del énfasis - por lo general poco marcado en interrogaciones retóricas, exclamaciones, vocativos, etc. - y las cláusulas expositivo-discursivas de conectores explícitos bien marcados. En el gráfico correspondiente a Herrera que incluimos en Apéndice -esquema 7- puede examinarse el detalle de la distribución de tales estructuras, tanto discursivo-enfáticas, como enfático-discursivas, especializadas, sobre todo estas últimas, en textos de apelación a la dama o al amor.

5.2.2. Las estructuras de construcción macrotextual más comunes en el caso de Herrera son, sin duda, las expresivo-discursivas, correspondiendo así a la expresión del mismo tenor de estilo sosegado de Garcilaso, sin la tensa vehemencia o el efectismo dramático de los sonetos de Lope de Vega. Una gran mayoría de los sonetos de Herrera corresponden, sin duda, a estructuras duales discursivas, con marcas de conexión explícita. El modelo estructural sintáctico lo especializó el poeta sevillano en la concreta expresión apelativa a la dama, sobre todo en el tipo sintáctico-semántico que definíamos en L. T. T. L. como galanteo. Siendo igualmente la estructura más frecuentada para el caso de la apelación al confidente bajo la forma de discreteo coloxuial, y, sobre todo, para la expresión lírica por excelencia del síntoma, forma y tema que recubre un gran número de los sonetos censados en Herrera, cuyo detalle puede consultarse en el gráfico adjunto.

Precisamente esta sobreabundancia de los textos con marcas explíci-

\footnotetext{
121 Mencionaremos algunos: 312, voc. / exclam. // disc. / imp.; 308, exclam. / disc. // exclam. / voc.; 279 , exclam / exclam. / exclam. / disc.; 159 y 229, voc. / voc. // disc. ] exclam.; 213 y 227, voc. / disc. // imp.; 205, exclam. / disc. // voc. / voc.; 297, voc. / disc. // voc. / disc.; 362, voc. / disc. // voc. / imp.; 387, disc. // voc. / imp. / disc. Por otra parte, clásulas enfáticas se distribuyen irregularmente en la estructura de los sonetos de isodistribución múltiple. Por ejemplo: énfasis + múltiple clímax, 116, 121, 132, 142, 201 y 232. Enfasis + tres cláusulas múltiples, 158, 183 y 320. Enfasis + voc. + dos cláusulas múltiples, 120. Múltiple + exclamativo + dos cláusulas múltiples, 259. Dos cláusulas múltiples + voc.-imp., 317, etc.
} 
tas lógico-discursivas constituye un rasgo tanto más marcado de la construcción textual de Fernando de Herrera, cuanto que su contrapartida, los sonetos expositivos de isodistribución dual sin marcas explícitas, es mucho más rara. Muy escasos son los textos de construcciones en paralelo ${ }^{122}$; no siendo mucho más abundantes los casos de isodistribución dual organizada en torno al modo que hemos denominado de agrupaciones intratextuales, es decir: "roles" de personajes, alternativas expresivas, etc. Si se consulta el gráfico correspondiente, puede verse que en el caso de estos sonetos de agrupaciones intratextuales, su mayor concentración responde al tipo de apelación al confidente. Herrera funda así un esquema textual sintáctico-semántico muy precisamente caracterizado, en el cual la alternativa entre el poeta y su interlocutor-confidente queda estructurada en formas muy bien perfiladas de paralelismo dual.

Sin embargo, ya en este punto, hemos de hacer una importante precisión. Como habremos de mencionar inmediatamente, la estructura básica de construcción macrotextual en los sonetos de Fernando de Herrera es la isodistribución múltiple. La pujanza de dicha forma de distribución estructural trasciende los sonetos estrictamente tales, catalogados así por nosotros en el gráfico correspondiente. En realidad, serían muy escasos los sonetos en que esta típica construcción de Herrera, que tendía a encerrar y ajustar las cláusulas sintáctico-argumentativas en las dimensiones concretas de las cláusulas rítmicas, no se hace presente. Muchos de los sonetos caracterizados por nosotros como de isodistribución dual con marcas explícitas discursivo-conectivas no lo son integralmente, sino en alguna de sus partes. En el caso de cualquier otro escrito, por ejemplo en el de Lope de Vega, hubiéramos dudado seriamente antes de no dar dichos sonetos como modalidad de isodistribución múltiple; pero en Herrera los textos con esta estructura múltiple son tan puros y estrictos, que no hemos dudado en clasificar los híbridos dentro del grupo menos numeroso de los duales-discursivos. Las combinaciones de tales casos de hibridismo más frecuentemente observadas serían: a) Múltiple/Múltiple $/ \%$ Discursivo/Discursivo ${ }^{123}$; b) Discursivo/Discursivo $/ \%$ Múltiple/. Múltiple ${ }^{124}$. Por último, $c$ ) Discursivo/Discursivo//Discursivo/Múltiple ${ }^{125}$ constituyendo casi esta última un caso mixto entre la antidistribución

122 Ocho en total hemos censado como tales: 44, 60, 75, 172, 198, 246 y 378.

123 Corresponden a ella sonetos como: $74,77,192,203,244,258,263,326,334,346$. 352, 370 y 410 , etc.

${ }^{124}$ Corresponden a ella sonetos como 85, 185, 204, 233, 235, 242, 247, 283, 328, 350 y 407, etc.

123 Combinación a la que corresponden, entre otros, los sonetos siguientes: 215, 234, 276, 298, 318, 327, 343, 367, 382, 388, 390, etc. 
-por cuanto la continuidad discursivo-conectiva desdibuja casi totalmente la cesura central del texto-, y la isodistribución múltiple enfática o la isodistribución dual mixta, en cuanto que el segundo terceto queda aislado como una "coda" especialmente evidenciada, tal como sucede - por causas distintas - en las dos estructuras mencionadas.

5.2.3. Con todo, la macroestructura argumentativa fundamental en Herrera es la de isodistribución múltiple. La distribución de sonetos testimoniada en el gráfico adjunto pone de relieve que casi la mitad de los textos muestreados de este autor han encontrado su forma de cabida en esta estructura; y aún, como acabamos de señalar, dicha nómina podría aumentarse fácil y rigurosamente sin esfuerzo, si se hubieran incluido en ella los sonetos con estructura múltiple parcial, tanto en la isodistribución dual discursiva como en la múltiple.

Creemos que la presencia de este rasgo sirve, mejor que cualquier otro, para caracterizar la producción lírica de Herrera, en la que - salvados todos los distingos estéticos que haga falta- a menudo se tiene la impresión de hallarse ante un conjunto escasamente variado y casi reiterativo. El pobladísimo cancionero del poeta sevillano repitió en muchísimos casos el mismo tipo semántico-temático, según ya tuvimos ocasión de constatar en L. T. T. L.; pero, como ahora advertimos, no lo hizo ni mucho menos sobre la base de una poblada gama de variaciones formales, sintáctico-argumentativas, sino, al contrario, asociando con mucha frecuencia tema y modalidad de construcción textual; lo que viene a producir en la consideración global del cancionero de Herrera esa cierta sensación de pesadez que no conoce el de los demás autores analizados. Con ello no pretendemos necesariamente una descalificación estética absoluta ni relativa de la lírica amorosa de Herrera, en ningún caso; sino la constatación de un rasgo de la misma, cuya explicitación nos parece que queda ahora satisfactoriamente explicada y justificada, y que podría of recer pautas muy fructíferas, aún inexploradas, en la elucidación de los problemas textuales y de autoría de las obras de Herrera.

Concretamente dentro del tipo que estamos comentando, la inmensa mayoría de los textos sintomáticos de isodistribución múltiple -que es, como puede comprobarse en el gráfico correspondiente, la clase con mucho más numerosa- responden a la estructura temática que en L. T. T. L. hemos designado como de «itinerario sentimental; es decir, exposición sucesiva de estados biográficos o de ánimo bajo la metáfora/o no de un camino recorrido, con una fuerte tematización inclusiva de la base temporal-narrativa, poco frecuente en la construcción lírica. Conviene aclarar, por último, respecto a las consideraciones que se refieren a esta estructura macroargumentativa privilegiada por Fernando de Herrera, 
que en la distinción dentro de la clase entre la estructura tipo y la marcada como "clímax» nos hemos movido con cierta provisionalidad de criterio; haciéndose, a nuestro juicio, imprescindible una revisión de los textos, antes de proceder a una afirmación categórica en un sentido $u$ otro ${ }^{126}$ entre dos límites estructurales tan próximos. Por lo general, hemos incluido como estructura en "clímax", aparte de las que evidentemente lo cumplían en razón de su constitución temática implícita, aquellas otras en que la presencia de partículas conectivo-conclusivas, sobre todo mas ó que, o de fórmulas enfáticas en el último terceto, establecían esta variación de tensión respecto al resto de la estructura múltiple.

La importancia del rasgo de presencia privilegiada de esta estructura macroargumentativa en Herrera nos obliga a notables consideraciones, no sólo en relación con Lope de Vega, sino con el conjunto general de nuestra lírica del Siglo de Oro - por lo menos de los autores fundi.nentales estudiados aquí por nosotros-. De la consideración de su frecuente presencia en Herrera y Quevedo, de la de su decisivo influjo como medida de la evolución temático-argumentativa de Lope de Vega, y sobre todo de su radical condición de ausencia en casos como el de Garcilaso y Góngora, cabe deducir su condición decisiva de alternativa expresiva en la lírica de nuestros poetas del Siglo de Oro. La isodistribución múltiple se ofrece, en este modo, como un modelo de expresión privilegiada, un tipo expresivo ordenado, encapsulado, en el que cada cláusula rítmico-sintáctica se constituye en una esfera de dialéctica interna, y el texto, como conjunto, se configura mucho más como orbe ambiental temático-argumentativo que como continuo de conexiones explícitas. La incidencia estilística e histórico-literaria de esta clase textual, cuya importancia venimos confirmando, corrobora su condición de alternativa modal textual básica, tal como la hemos puesto de relieve en nuestra tipología macroestructural de la construcción textual en el texto del soneto clásico.

5.3. Moldes de macroestructura argumentativa en la lírica conceptista: Quevedo

5.3.1. Quizá ninguno de los poetas analizados, ni siquiera Góngora, definió de un modo tan decisivo y constante un tipo estructural macroargumentativo para dar expresión a la temática amorosa como Que-

\footnotetext{
126 Reiteramos una vez más aquí las razones de provisionalidad y urgencia de este trabajo en el sentido y términos que lo hicimos en su introducción.
} 
vedo. Frente a la poderosa variedad estructural de Lope de Vega, Quevedo fija un tipo de construcción, la isodistribución múltiple, y lo reitera en la mayor parte de sus composiciones. Ya se ha indicado cómo este modelo argumentativo es el que más tenazmente manifiesta la concentración de la idea. El doble cierre clausular de la métrica y la sintaxis en cada estrofa sirve para destacar la rotundidad del pensamiento contenido; mientras que su reiteración esencial, desarrollada o restringida. a lo largo de la cuadruple repetición estrófica, supone una dialéctica ingeniosa, una ascesis para la agudeza que tensa la poderosa estructura funcional de partes en el soneto sin la apoyatura de las marcas, conectoras o enfáticas. Como en el estilo de la prosa, el conceptismo en poesía, representado aquí por Quevedo, se caracteriza, a través de la isodistribución múltiple, por su manifiesta tendencia al discurso abrupto y entrecortado, en el que todas las vías de conexión explícita desaparecen, vaciadas y presentes paradójicamente en el juego del propio ingenio, que ha de adivinarlas y suplirlas.

La asociación llevada a cabo por Quevedo de este tipo argumentativo a una temática más variada e intimista que Herrera, hace por lo demás que la proximidad observable en ambos respecto a la multiplicidad de empleo de este recurso no deba ser explotada en exceso como marca de afinidades. Fundada en la asociación a una temática más variada y libre en el caso de Quevedo, el fruto de esta síntesis temático-argumentativa no resulta nunca tan monótono y hasta carente de sorpresas como, examinado el conjunto general de la producción de Herrera, puede llegar a resultar ésta. A nuestro juicio, Quevedo fundamenta la lírica conceptista, como perfiló la prosa, con los recursos constructivos equivalentes a los de ésta, que en el caso del soneto es la isodistribución múltiple.

Las marcas enfáticas son planta rara en la lírica de Quevedo, a diferencia de la del primer Lope. En tal sentido, podemos considerar quizá la evolución estilístico-argumentativa de la lírica de Lope, tal como la há evidenciado este trabajo, como una tendencia, si no influida directamente por Quevedo, sí desde luego partícipe de una corriente general de la poesía española en el primer tercio del siglo XVII a las estructuras normalizadas y al tono doctrinal y reflexivo, en progresivo abandono de efectismos y distorsiones. Resulta claro para todos los críticos de Lope su constante y prudente militancia anticulterana; en tal sentido, como veremos inmediatamente, también en sus sonetos amorosos Góngora definía estructuras argumentativas fundamentalmente distorsionadas y efectistas, prodigando desproporcionadamente la antidistribución. Quizá como reacción anticulterana, y seguramente - como ya hemos dicho- 
como consciente reacción antitópica, Lope de Vega progresó hacia la isodistribución múltiple, precisamente como una modalidad expresivoargumentativa que él consideraba a la vez conservadora y sobre todo natural, antiefectista. En tal sentido, la engañosa moderación aticista del conceptismo - lo hemos dicho ya muchas veces-jugó en todos los casos como la baza conservadora y tradicional, frente al culteranismo, en la estimativa de la sociedad literaria contemporánea; siendo, en realidad, por lo menos tan radicalmente revolucionario y barroco como éste. El testimonio contrastado de este detalle concreto de la argumentación macroestructural en los sonetos entre tres autores, Lope, Quevedo y Góngora, refuerza también la aseveración general.

5.3.2. Como ya se ha dicho, el número de los sonetos con marcas enfáticas en Quevedo es muy restringido. Casi exclusivamente la modalidad vocativo/imperativo en apelación a la dama es la única registrada $^{127}$, e incluso el orden del énfasis es muy irregular; pues, frente a un número considerable de textos - ver lista en el apéndice correspondiente- apelativos a la dama o al confidente con la distribución enfático/discursiva, sólo se registra el caso de un texto, el 121 (p. 219), el famoso "Amor poderoso más allá de la muerte», en el que se ofrece cierta entidad enfático-vocativa -y no totalmente- en los tercetos.

Dentro de los textos con estructura de isodistribución dual ofrece algún dato de cierta consideración y curiosidad el caso de los sonetos sin marcas en distribución de agrupaciones intratextuales. La estructura es, en principio, dificilmente separable de la múltiple, al no contar con marcas explícitas que establezcan la isodistribución dual. Sólo se diferencian ambas clases, como sabemos, en determinadas formas de solidaridad y proporcionalidad paralela, que determinan la organización en dos unidades-cláusulas o en cuatro. Pero lo realmente curioso es que, con alguna muy concreta excepción ${ }^{128}$, la totalidad de sonetos que representan esta construcción aparecen en el Canto de Lisi ${ }^{129}$, y no en las demás

127 Utilizamos la edición popular de Blecua de la Poesia metafísica y amorosa de Quevedo, Madrid, Planeta, 1976, igual que hicimos en L. T. T. L. Remitimos en cada caso a la página de la edición mencionada en que se inicia el texto del soneto, precedida del numero de orden que cada composición tiene dentro del grupo de poemas amorosos, si bien tal número no está explícitamente indicado en la edición mencionada. Los sonetos apelativos a la dama son: 31 (63), 42 (71), 69 (89), 95 (201), 102 (206) y 119 (218).

126 La constituyen los sonetos: 88 (100), 67 (88) y $40(70)$.

120 Un tipo muy frecuentado por Quevedo, encuadrable entre esta estructura y la múliple, es el de textos múltiples con interrogación retórica en el primer cuarteto. Algunos ejemplos del Canto a Lisi son: 91 (200), 100 (205), 102 (206), 109 (211), 123 (220), 124 (221), etc. 
composiciones anteriores de Quevedo; con lo que puede hablarse, también en el caso de Quevedo, de esta modalidad estructural macroargumentativa -que por lo demás es siempre apelativa directa a la dama-, como de un rasgo evidente de evolución estilística. Con todo, debemos insistir en que, tratándose de un tipo estructural tan próximo al tan frecuentado de la isodistribución múltiple, no resulta siempre fácil ni evidente el establecimiento de sonetos de esta clase ${ }^{130}$; consideración que se podría extender quizás a los sonetos de naturaleza híbrida múltiple-discursiva ${ }^{131}$.

El tipo múltiple, tan abundante, lo hemos redistribuido en dos grupos, el vario y el climax, respondiendo por lo general esta última modalidad al conjunto de indicaciones que hemos hecho para Lope de Vega, o para Fernando de Herrera; pero insistiendo en que no consideramos profunda ni.definitivamente fundada la diferencia entre estos dos subconjuntos tipológicos.

Digamos, finalmente, que en Quevedo abundan, en especial fuera del Canto de Lisi, los sonetos de antidistribución, especializados en la apelación enfática a la dama - ver el gráfico correspondiente-. En la mayor parte de los casos la antidistribución es de la clase más impura, plurisentencial; pero también se registran estructuras unisentenciales, las mejores quizá sean las de dos famosos sonetos de enumeración antitética, típicos exponentes de la definición del sentimiento amoroso. El soneto 50 (p. 77), "Muestra lo que es una mujer despreciada", y el 83 (p. 97), "Soneto amoroso definiendo el amor", pueden figurar en la antología de las más puras muestras del género. También fuera del Canto de Lisi se puede señalar la presencia de sonetos narrativos, incluso con indicios de dramatización, que ensanchan y generalizan esta tendencia tan característica del cancionero de Lope de Vega. Pero su escasez y rareza en el conjunto de sonetos de Quevedo, como en el de los demás escritores donde los hemos encontrado, no restringen en absoluto la originalidad - nos diremos el acierto- de la decisión estilistica de Lope al implantarlos tan frecuentemente en su producción.

\footnotetext{
${ }^{130}$ Son muy numerosos los sonetos dudosos que, considerados por nosotros como no múltiples, ofrecen sin embargo muy severas razones de vacilación. Por ejemplo, el 42 (71). calificado como voc./imp.; el 52 (78), 53 (79), 64 (86), 65 (86) y 122 (220), calificados como enfático/discursivos; el 67 (88), 88 (100), 97 (203) y 133 (227), calificados como duales en construcciones intratextuales, pueden considerarse múltiples desde otra perspectiva.

${ }^{131}$ Quevedo frecuentó una estructura, absolutamente fijada, de textos de esta índole en el Canto a Lisi. Es la que sigue el esquema: inúltiple/múltiple // conect. (si)/conect. (mas). Ejemplos: 118 (217), 126 (222), 127 (223), 140 (232), 142 (233), 148 (237) y 150 (239).
} 
5.4. El énfasis barroco en las estructuras antidistributivas de Góngora

5.4.1. En ninguno de los escritores censados, ni siquiera en el caso del Lope juvenil tan enfático y apegado a la tópica tradicional, se registra una concentración de sonetos antidistributivos tan poderosa como en los amorosos de Góngora. Si a esta característica, que consideramos ya de suyo definidora, unimos las otras dos observaciones más regulares y pertinentes que nos brinda el análisis macroargumentativo de sus sonetos amorosos, a saber: la fidelidad asociativa de macroestructuras argumentativas y tipos temáticos y la marcada rareza de sus composiciones sintomáticas, creemos que se ofrece, explícita, la base analítica de nuestra propia $-y$ no creemos, ni mucho menos, que exclusiva - estimación estilística del gran poeta cordobés. Sin duda fue Góngora el más alto y artificioso de nuestros poetas lírico-amorosos, pero desde luego se nos presenta como el más distanciado de cualquier propia emoción, de cualquier modo de transparencia biográfica. Frente a las frecuentes acusaciones de sus envidiosos contemporáneos, frente al escándalo del Góngora sacerdote y afortunadísimo poeta, nada mejor que la simple lectura de sus poemas para acallar cualquiera de tales críticas. Así parecía sentirlo también el indiferente y altanero Góngora.

La frecuente presencia de tipos antidistributivos en su cancionero amoroso atestigua la tendencia general más marcada en Góngora: la disolución de la cesura central del soneto, su resolución de la complejidad sintáctica en un eje unisentencial único del poema, que va distribuyendo a lo largo del texto los elementos de la aseveración única, elegantemente completados con exornaciones marginales. En tal sentido, quizá el texto antidistributivo en el que culmina más genuinamente la tendencia general estilística de Góngora sea el 62, «Rey de los otros, río caudaloso» ${ }^{132}$, soneto de confidente al río Guadalquivir. De índole más

${ }^{132}$ En el caso del soneto gongorino fue precoz y laudable iniciativa la de $O$. Frattoni, Ensayo para una historia del soneto en Góngora, Buenos Aires, 1948. Y resulta imprescindible mencionar la rigurosa pauta general brindada por Robert Jammes, Études sur l'oeuvre poétique de Don Luis de Góngora, Burdeos, 1967. Véase el texto aludido, 62 (120). Citaremos siempre por el número del soneto y página en la siguiente edición de Góngora: Sonetos Completos, Madrid, Castalia, 1969, de B. Ciplijauskaité.

Rey de los otros, río caudaloso, que en fama claro, en ondas cristalino, tosca guirnalda de robusto pino ciñe tu frente, tu cabello undoso, pues, dejando tu nido cavernoso de Segura en el monte más vecino, por el suelo andaluz tu real camino tuerces soberbio, raudo y espumoso,

a mí, que de tus fértiles orillas piso, aunque ilustremente enamorado, tu noble arena con humilde planta, 
convencional, con solución al fïnal de la unisentencia, es el 82, "Cosas, Celalba mía, he visto extrañas", que destacado tradicionalmente por la crítica como estructura característica del Manierismo, puede contemplarse ahora, desde su generalización como tipo antidistributivo, en la dimensión real histórico-literaria del recurso.

5.4.2. El segundo de los testimonios del convencionalismo fuertemente artificioso de Góngora brilla, como hemos dicho, en su cerrada distribución de clases de construcción y clases temáticas. Así, la totalidad de sonetos con estructura vocativo/imperativo se alía con la apelación al confidente ${ }^{133}$, mientras que, por el contrario, la apelación a la dama se especializa básicamente en el tipo de isodistribución múltiple con clímax marcado, aparte, claro está, del recurso mayor de la antidistribución. También a la argumentación confidencial va asociada la problemática clase de isodistribución dual sin marcas por paralelismo ${ }^{134}$, rasgo que nos pone sobre la pista de otra nueva evidencia de la falta de apasionamiento autobiográfico en la lírica amorosa de Góngora, pues no ha existido quizá en nuestro Siglo de Oro un sentimiento más participado, ya que son tantos los sonetos en apelación al confidente como a la misma dama (véase a tal efecto el gráfico correspondiente).

Todavía otro rasgo sintáctico macroargumentativo pudo venir a reforzar la consideración global antibiográfica de la lírica de Góngora. Lo define esta vez la exagerada proporción de sonetos representativos, diez en total, frente a la exigüidad de los sintomáticos: cuatro textos. No ya sólo los sonetos expresamente considerables de amores ajenos, como el 93 y el 99, a la consumación del matrimonio de Felipe IV, sino la gran totalidad de los pastoriles, en los que, pese a los posesivos - mi pastora», etc.-

\footnotetext{
dime si entre las rubias pastorcillas

has visto, que en tus aguas se han mirado,

beldad cual la de Clori, o gracia tanta.
}

${ }^{133}$ Uno de los sonetos representativos de este tipo, el $68 \rightarrow$ Culto Jurado, si mi bella dama"-, evidencia muy claramente la tendencia de Góngora a deshacer la cesura central del soneto, alargando sencillamente la estructura sintáctico-semántica del segundo cuarteto hasta el verso inicial del primer terceto. (aso semejante, y aún más marcado, lo ofrece el soneto 97.

${ }^{134}$ El problematismo para su clasificación macroargumentativa de este grupo de sonetos resulta evidente. El 57 es en realidad un soneto múltiple construido con vocativo en cada estrofa-cláusula. No sólo paralela, sino sobre todo enfática es la estructura de kos sonetos dobles 61, 77 y 90, con doble distribución voc./imp. // voc./imp. No menos problemático resulta el otro grupo de estruxturas con paralelismo apelativo a la dama constituido por el soneto 70, en realidad un doble enfático, y el 81, que, por encima de la organización paralela dirigida por los lexemas anafóricos temoltemo, pudiera catalogarse sencillamente de múltiple. 
deslizados, se impone el tono general de desvinculación personal del autor, que nos ha llevado a catalogarlos, sin duda alguna, de textos en representación narrativa, es decir, absolutamente desvinculados del yo sujeto de la enunciación ${ }^{135}$.

5.5. Conclusión. La originalidad de Lope de Vega también patente en la sintaxis macrotextual

Presupuesto inicial de este trabajo fue, como hemos repetido muchas veces, el tópico general de la crítica sobre Lope de Vega, su genial fecundidad, su capacidad de renovación en el ámbito del teatro. Temáticamente analizada su lírica, al menos su lírica amorosa - y no existen razones en contra para generalizar el aserto-, testimonia el mismo rasgo de independencia personal. Cierto que los parámetros tópicos de los que se partía en ambas tradiciones, la teatral y la de la poesía lírica, eran bien distintos, con lo que la innovación lírica fue sin duda menos llamativa que la dramática, de ahí también que a la crítica le haya pasado más inadvertida, presentándonos quizá un Lope de Vega sólo parcialmente revolucionario en el caso del teatro.

Pero los revolucionarios en arte no pueden sino procurar la revolución total. Y Lope, como testimonia incluso una revisión superficial de su temática lírica ${ }^{136}$, fue más que un modificador, un verdadero crítico integral de dicha temática; pudiendo afirmarse que trató -consciente o inconscientemente- de no ser fiel a ninguno de los tópicos, de conculcar incluso las leyes básicas que regían el entendimiento consensuado en poesía de la pasión cortés, y hasta de revisarla paródicamente, tópico por tópico, al final de su vida en el Tomé de Burguillos.

El estudio realizado en este trabajo ratifica dicha voluntad innovadora hasta sus últimas consecuencias. En el plano de las estructuras formales, de la construcción macrotextual o de la macroargumentación -quizá, incluso, conscientemente menos presente a la reflexión de los escritores clásicos que la temática misma-, Lope partió del espectro estructural

${ }^{135}$ Ejemplos de esta ficción bucólica, mitológica o pastoril, serían: $54,55,58$ y 86 . El 80 tematiza sobre la propia pasión una historia ajena, mientras el 95 y 96 narran una peripecia accidentada sin intervención del poeta.

136 Esperamos publicar en breve una prolongación del sector temático de nuestra teoría general sobre la tipología de la lírica clásica, dada ya a conocer en L. T. T. L. En dicho trabajo estudiaremos las peculiaridades de distribución del complejo tópico-temático que constituye la lírica amorosa de nuestros principales autores clásicos. El caso de Lope de Vega nos ha ocupado fundamentalmente en el estudio anunciado como uno de los más radicalmente innovadores. 
más amplio que registra ninguno de nuestros grandes creadores clásicos. Desde el inventario de macroformas constructivas de Lope pueden definirse, y así lo hemos hecho, la inmensa mayoría de las estructuras peculiares de todos los demás grandes creadores. En tal sentido, podemos decir que Lope agotó ya inicialmente las posibilidades que le ofrecia la tradición tópica de la lírica en el plano de la sintaxis textual. Desde dicho punto de partida, como hemos visto, Lope fue evolucionando también formalmente, seleccionando las estructuras más adecuadas a su juicio a la expresión personal, recorriendo un itinerario en todo muy similar al que se perfila dentro de la lírica conceptista de Quevedo, como consciente y sistemática demolición del sistema de efectismos tópicos, que contemporáneamente, en ciertas estructuras al menos, pasó a representar el culteranismo.

Antonio Garcia Berrio Universidad de Bielefeld. Semestre de Verano, 1979. 


\section{APÉNDICE}

\section{CONTENIDO}

CUADRO 1. Distribución de los sonetos de las Rimas. El número indica el correspondiente a cada soneto en la edición de 1609. Los números en cursiva indican sonetos de contenido no amoroso.

(UUADRO 2. Distribución de los sonetos de las Rimas sacras. El número indica el correspondiente a cada soneto en la edición de 1614 .

CUADRO 3. Distribución de los sonetos de La Filomena y La Circe. Los números en cursiva corresponden al número de página de La Filomena en la edición de Blecua. En los de La Circe se da - no subrayados- primero el número de cada soneto en el orden en que se presenta en la edición de Blecua, seguido entre paréntesis de la página en que aparecen en la mencionada edición.

CUADRO 4. Distribución de los sonetos en las Rimas de Tomé de Burguillos. Se da primero el número que corresponde a cada soneto en la edición de 1634, añadiéndose entre paréntesis la página correspondiente en la edición utilizada de Blecua.

(UUADRO 5. Distribución de los sonetos amorosos de Garcilaso de la Vega. Se da el número de orden tradicional en todas las ediciones del autor.

CUADRO 6. Distribución de los sonetos amorosos de Fernando de Herrera. Se indica el núnıero de orden de cada soneto, en la edición de Blecua de las Obras (Real Academia Española).

CUADRO 7. Distribución de los sonetos amorosos de Quevedo. Se indica primero el número de orden que les corresponde dentro del apartado correspondiente (amorosos) en la edición citada de Blecua, a continuación, entre paréntesis, el número de la página.

CUADRO 8. Distribución de los sonetos amorosos de Góngora. Se indica el número de orden en la edición utilizada de B. Ciplijauskaité. 


\begin{tabular}{|c|c|c|c|c|c|c|c|c|}
\hline & (1) & $A$ & D() & A P & ELACION & & & \\
\hline & & & & $\begin{array}{c}\text { DAMA } \\
\text { (Objeto principal) }\end{array}$ & $\begin{array}{l}\text { CONFI- } \\
\text { DENTE }\end{array}$ & $\begin{array}{l}\text { POETA } \\
\text { MISMO }\end{array}$ & SINTOMA & $\begin{array}{l}\text { RE.PRESEN- } \\
\text { TACION }\end{array}$ \\
\hline & & & 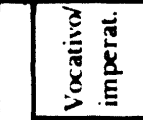 & $\begin{array}{rrr}46 & 58 \cdot 121 \\
125 & 140 & 152 \\
171 & 189 & \\
\end{array}$ & 36 & $\begin{array}{lll}136 & 145 & 150 \\
190 & & \end{array}$ & & \\
\hline & & & 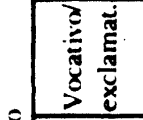 & $\begin{array}{rrr}81 & 147 & 163 \\
195 & 197 & \end{array}$ & 130 & 63 & & \\
\hline & & $\frac{a}{\frac{3}{2}}$ & 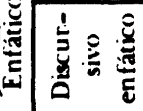 & $\begin{array}{r}39 \\
164\end{array}$ & $28 \quad 173$ & $\begin{array}{lll}70 & 101 & 156\end{array}$ & $\begin{array}{ccc}2 & 7 & 11 \\
20 & 22 & 33 \\
40 & & \\
\end{array}$ & \\
\hline 2 & द & हُ & 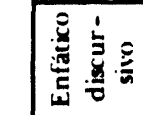 & & & 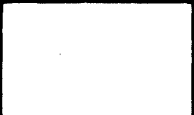 & & \\
\hline$\infty$ & 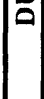 & 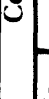 & $\stackrel{\Xi}{\underline{\underline{x}}}$ & $\begin{array}{rrr}41 & 62 & 72 \\
135 & 143 & \end{array}$ & $1 \quad 1045$ & & & \\
\hline \begin{tabular}{l|l}
2 & \\
0 & 1 \\
0 & 0 \\
0 & 0
\end{tabular} & & & 选 & $\begin{array}{rrr}15 & 43 & 67 \\
153 & 165 & 169 \\
184 & & \end{array}$ & $\begin{array}{rrr}8 & 51 & 47 \\
119 & 120 & 197\end{array}$ & 141 & & 107 \\
\hline $\mid \begin{array}{ll}0 & 0 \\
2 & 1 \\
x & \\
1 & \end{array}$ & & $\frac{1}{8}$ & 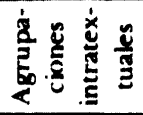 & $\begin{array}{|rrrr|}17 & 59 & 60 & 74 \\
85 & 88 & 104 & 105 \\
111 & 139 & & \\
\end{array}$ & $\begin{array}{rrr}66 & 82 & 115 \\
129 & & \end{array}$ & $158 \quad 161$ & $\begin{array}{rrr}29 & 48 & 182 \\
185 & & \end{array}$ & \\
\hline & & 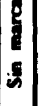 & 这 & $\begin{array}{rrrr}25 & 34 & 44 & 49 \\
53 & 76 & 87 & 113 \\
168 & 178 & 180 & \end{array}$ & $\begin{array}{rrr}50 & 54 & 89 \\
114 & 128 & 138 \\
162 & 183 & 188\end{array}$ & $93 \quad 97$ & $23 \quad 123$ & $196 \quad 197$ \\
\hline & 넌 & & 芯 & $\begin{array}{rrr}38 & 62 & 71 \\
106 & 159 & 193\end{array}$ & $\begin{array}{lll}55 & 73 & 92\end{array}$ & 103 & $75 \quad 78$ & 24 \\
\hline & 5 & & ) & $\begin{array}{lll}146 & 157 & 168 \\
176 & 179 & 200\end{array}$ & $42 \quad 79$ & $151 \quad 154$ & $191 \quad 199$ & 86 \\
\hline है & & & $\frac{1}{8} \frac{\pi}{8}$ & $\begin{array}{rrr}3 & 32 & 96 \\
99 & 117 & 131 \\
137 & 142 & \\
\end{array}$ & 198 & 102 & $\begin{array}{lll}27 & 76 & 110\end{array}$ & \\
\hline$\frac{6}{3}$ & & & $\dot{8} \frac{1}{8}$ & $14 \quad 69 \quad 155$ & $\begin{array}{lll}9 & 12 & 160\end{array}$ & & $\begin{array}{rrrr}6 & 13 & 52 & 36 \\
61 & 126 & 127 & 132 \\
134 & 149 & 170 & \end{array}$ & \\
\hline & से & & है & & & & $\begin{array}{rrr}19 & 68 & 98 \\
148 & 175 & \end{array}$ & $\begin{array}{rrr}39 & 57 & 87 \\
118 & 174 & 181 \\
186 & 187 & \end{array}$ \\
\hline$\frac{z}{0}$ & R & & $\frac{\dot{2}}{2}$ & & & & 45 & $\begin{array}{lll}41 & 70 & 84 \\
87 & & \end{array}$ \\
\hline$\underset{z}{\alpha}$ & 닐 & & $\frac{8}{8}$ & & & & $64 \quad 166$ & $\begin{array}{rrr}16 & 30 & 91 \\
116 & 172 & 194\end{array}$ \\
\hline & 5 & & $\frac{1}{2} \cdot 3$ & & & & $21 \quad 26 i 24$ & $\begin{array}{rrr}18 & 35 & 90 \\
122 & & \end{array}$ \\
\hline
\end{tabular}




\begin{tabular}{|c|c|c|c|c|c|c|c|c|c|c|}
\hline & CL: & ADRC & () 2 & & & $A P$ & $1 .+(1)$. & & & \\
\hline & & & & I & $\begin{array}{l}\text { DICSS } \\
\text { (1) prir }\end{array}$ & ncipal) & (coNt- & $\begin{array}{l}\text { Mr)til } \\
\text { MISilo }\end{array}$ & six/OMt & I. \\
\hline & & & 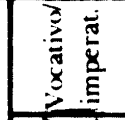 & $\begin{array}{l}40 \\
75\end{array}$ & $\begin{array}{r}66 \\
100\end{array}$ & & 3750 & 8 & & \\
\hline & & & 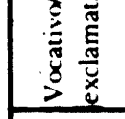 & $\begin{array}{l}33 \\
63\end{array}$ & $\begin{array}{r}46 \\
85\end{array}$ & $\begin{array}{l}57 \\
91\end{array}$ & & 2 & & \\
\hline & & 吾 & $4 \frac{1}{3}$ & $\begin{array}{l}21 \\
47 \\
58\end{array}$ & $\begin{array}{l}25 \\
49 \\
84\end{array}$ & $\begin{array}{l}31 \\
54\end{array}$ & & $16 \quad 2026$ & 4 & \\
\hline 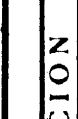 & $\mid$ & 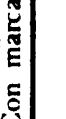 & 畄 & $\begin{array}{l}11 \\
59 \\
89 \\
\end{array}$ & $\begin{array}{l}17 \\
77\end{array}$ & $\begin{array}{l}27 \\
87\end{array}$ & . & 72 & 512 & $52 \quad 71$ \\
\hline a & & & $\stackrel{g}{\underline{x}}$ & $\begin{array}{r}6 \\
67\end{array}$ & 15 & 56 & & & & \\
\hline $\begin{array}{l}0 \\
0 \\
0 \\
n \\
n\end{array} \mid \frac{n}{n}$ & & $\int_{\tilde{z}}^{2}$ & 竞。 & 81 & 96 & & & 44 & 1 & 60 69 \\
\hline $\mid \begin{array}{l}0 \\
0 \\
x \\
w \\
w\end{array}$ & & 常 & c & 51 & & & 19 & 42 & $\begin{array}{lll}36 & 44 & 94\end{array}$ & 55 \\
\hline & & 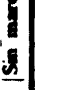 & 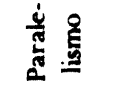 & $\begin{array}{l}29 \\
80\end{array}$ & $\begin{array}{l}92 \\
83\end{array}$ & $\begin{array}{l}38 \\
86\end{array}$ & 61 & 34 & & \\
\hline & 幽 & & 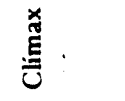 & 14 & 39 & & & 10 & $3 \quad 9 \quad 43$ & \\
\hline & 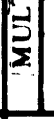 & & $\frac{8}{4}$ & $\begin{array}{l}22 \\
41 \\
98 \\
\end{array}$ & $\begin{array}{l}23 \\
90 \\
99 \\
\end{array}$ & $\begin{array}{l}28 \\
97 \\
\end{array}$ & 35 & 7 & 13 & \\
\hline $\mid$ & & & 焉 & & & & & & & \\
\hline 旁 & & & 爮 & & & & & & & \\
\hline & K & & 률욜 & & & & & & 18 & $\begin{array}{lll}30 & 68 & 76 \\
82 & 92 & 99\end{array}$ \\
\hline $\begin{array}{l}z \\
0 \\
u \\
<\end{array}$ & $\theta$ & & 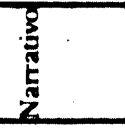 & & & & & & & $\begin{array}{lll}64 & 65 & 70 \\
78 & 79 & 95\end{array}$ \\
\hline$\underset{x}{\alpha}$ & تئت & & 密 & & & & & & & 53 \\
\hline & है & & 宽 & & & & & & 2445 & 6274 \\
\hline
\end{tabular}




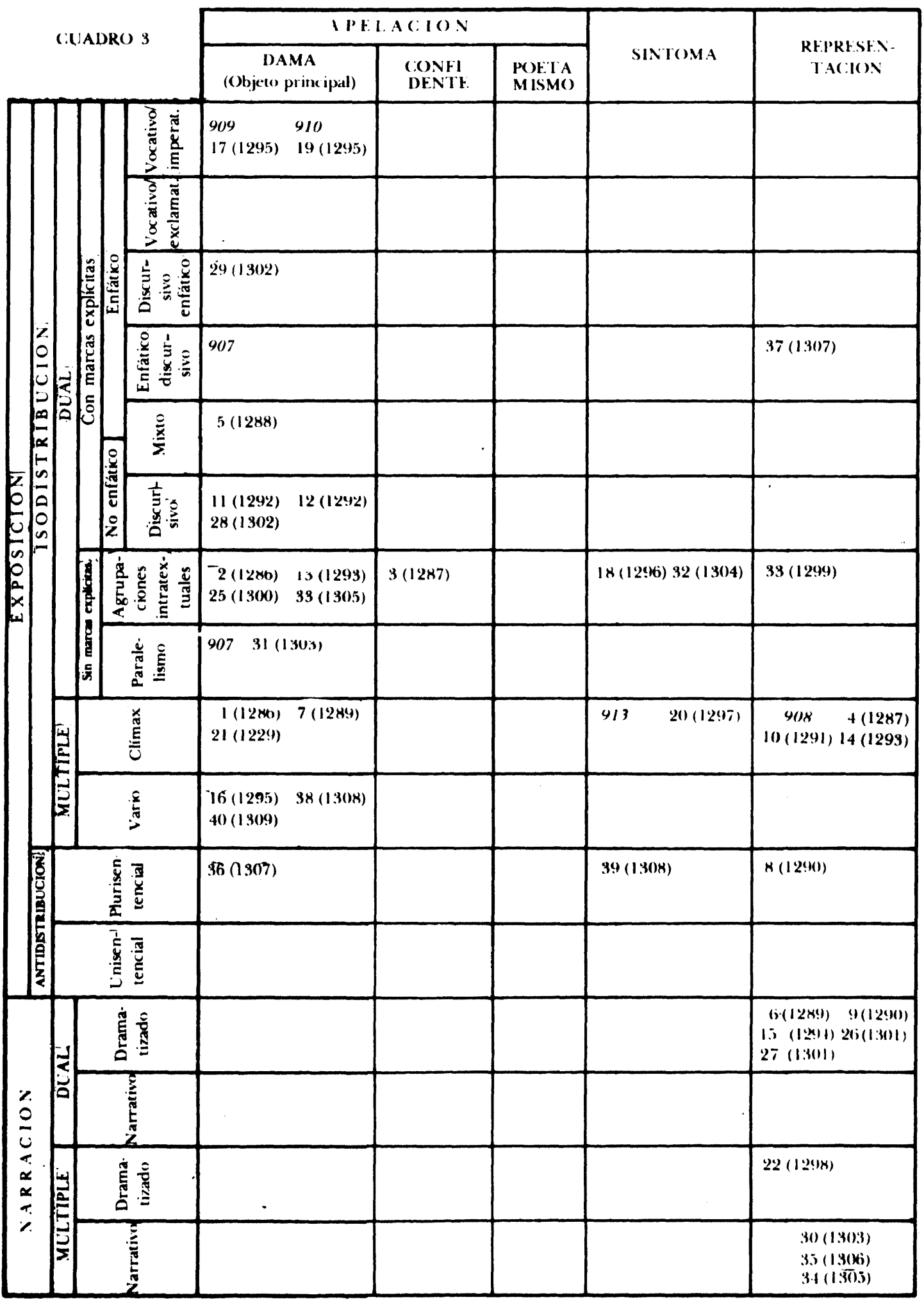




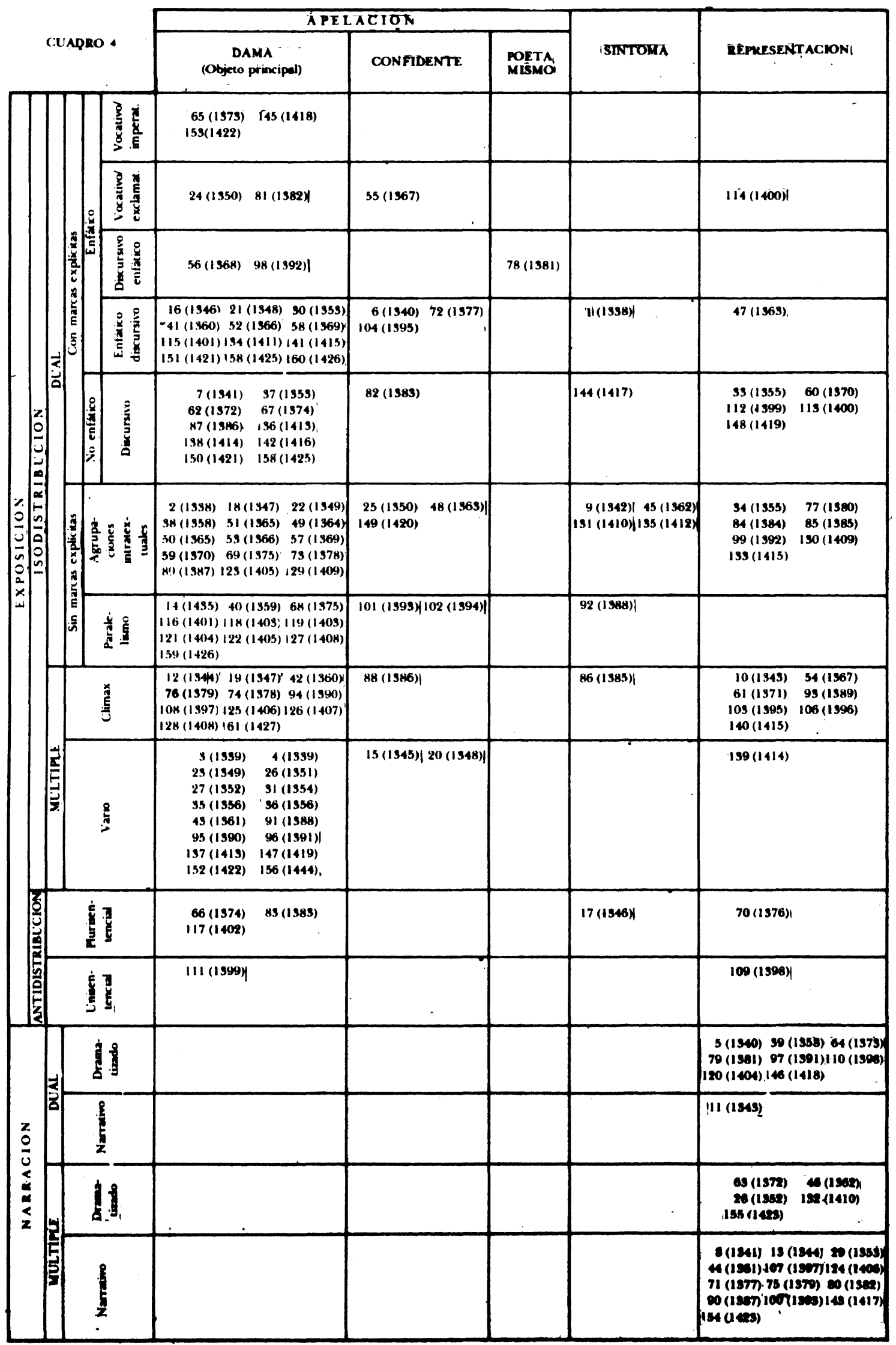




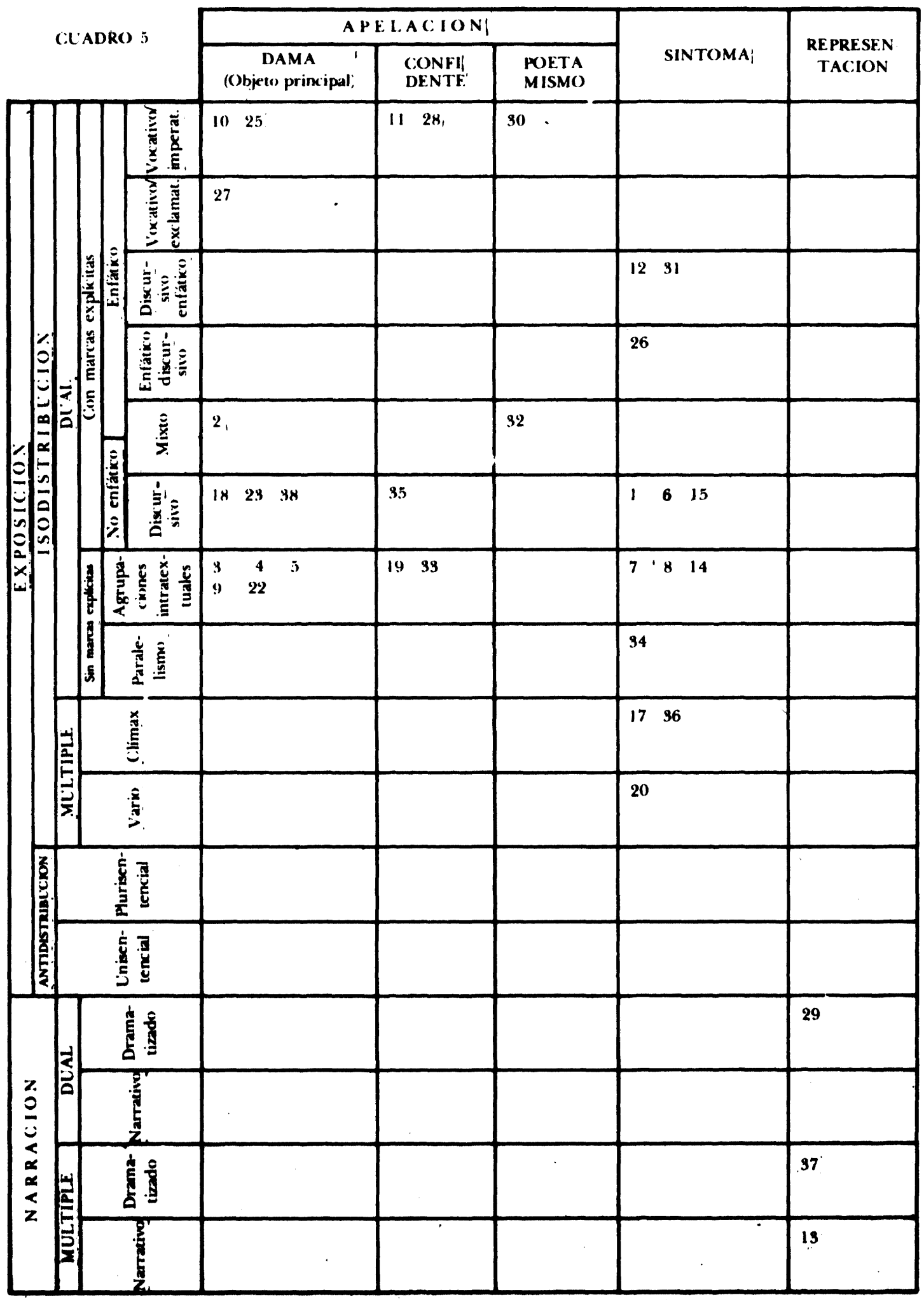




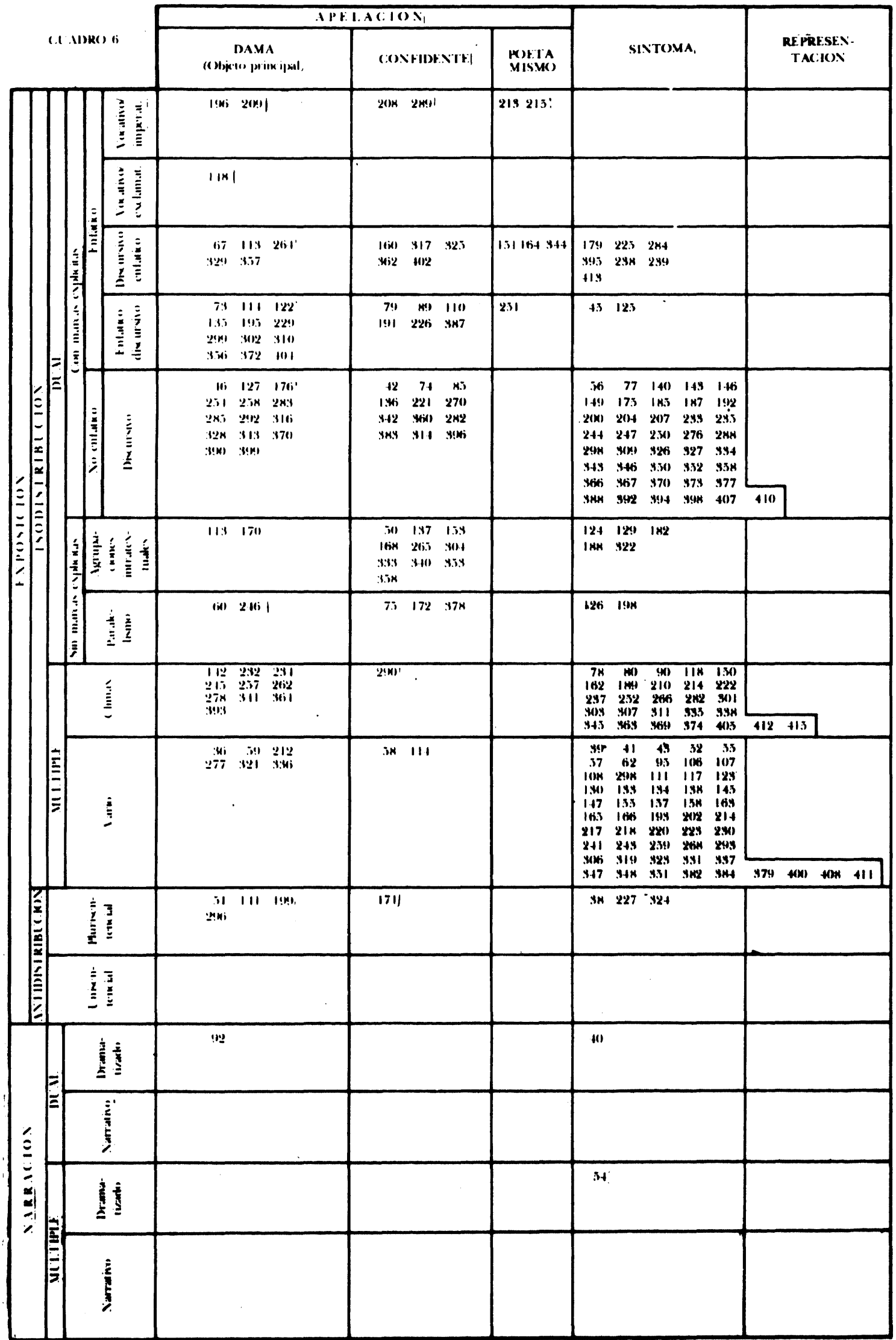




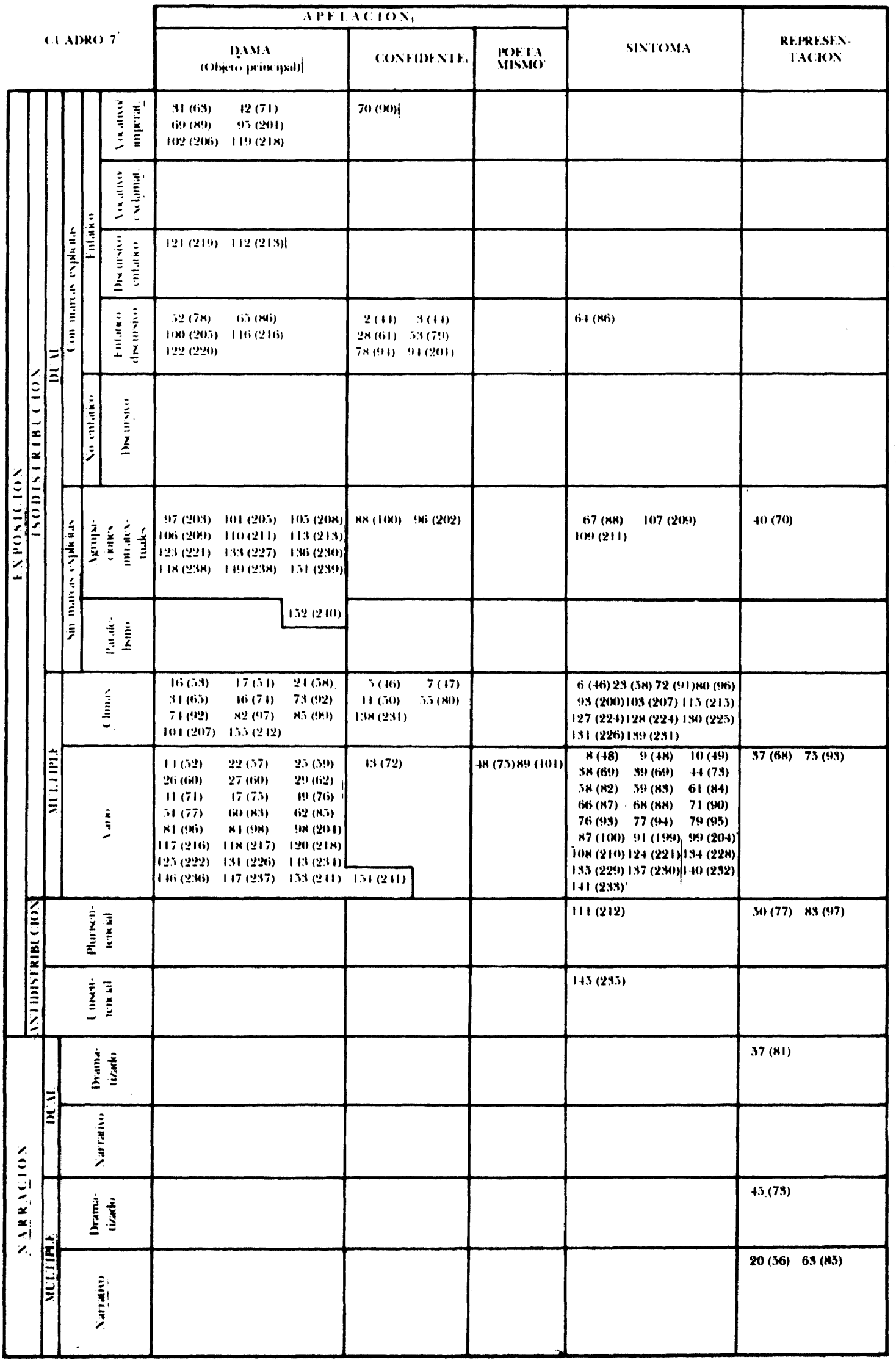




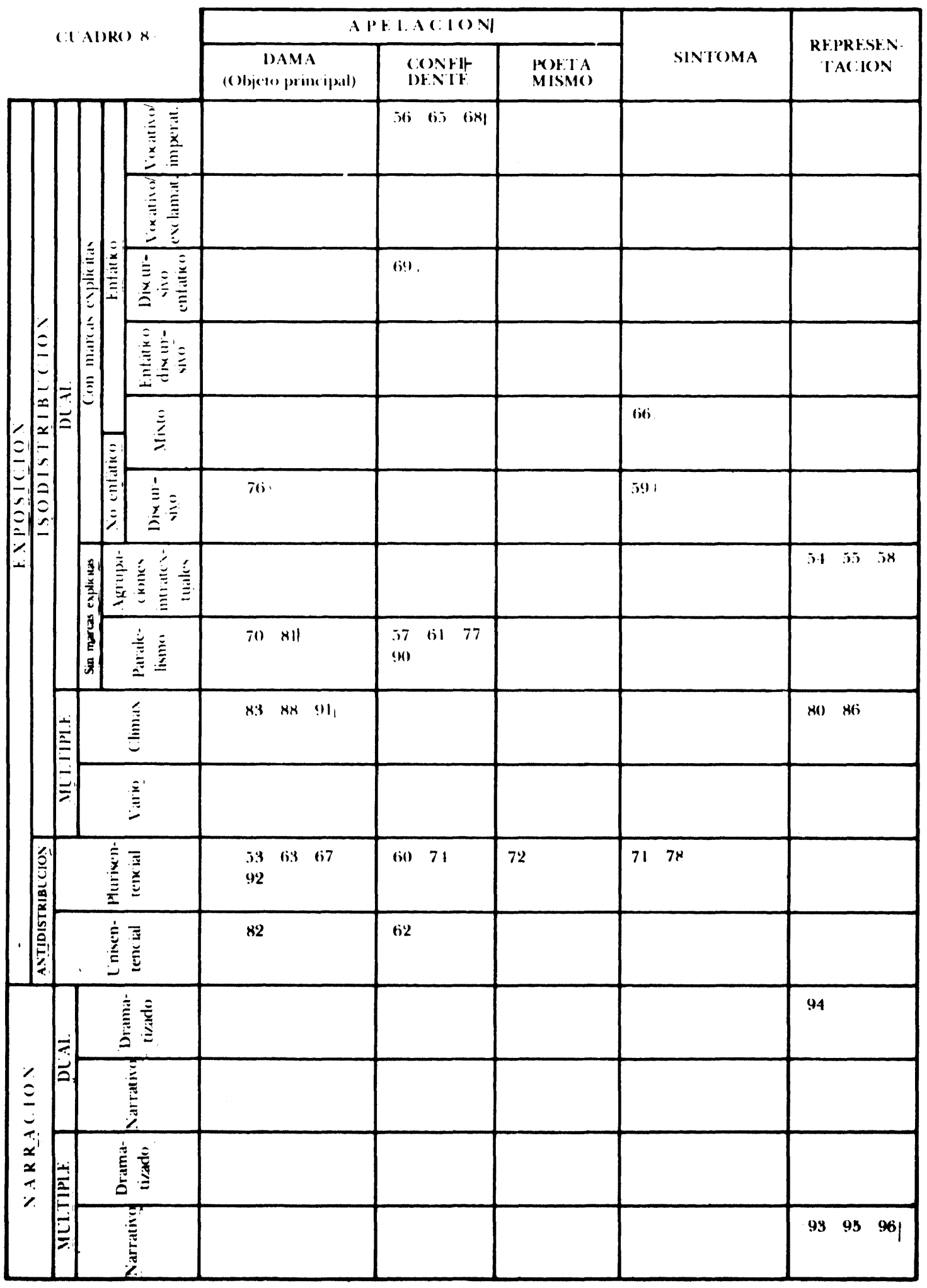

